\title{
COMPUTATION OF POROSITY AND WATER CONTENT FROM GEOPHYSICAL LOGS, YUCCA MOUNTAIN, NEVADA
}

by Philip H. Nelson

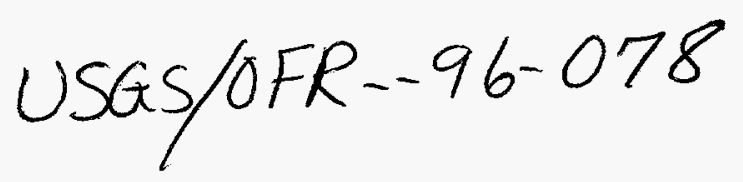

U.S. Department of the Interior

U.S. Geological Survey

Open-File Report 96-078

\section{RECEIVED \\ APR 071998 \\ OSTI}

Distrisution Of thils DOCUMENT is UNLMTED,

Prepared in cooperation with the

U.S. Department of Energy,

Nevada Field Office, under

Interagency Agreement DE-AI08-92NV10874

Denver, Colorado

1996 


\section{DISCLAIMER}

This report was prepared as an account of work sponsored by an agency of the United States Government. Neither the United States Government nor any agency thereof, nor any of their employees, makes any warranty, express or implied, or assumes any legal liability or responsibility for the accuracy, completeness, or usefulness of any information, apparatus, product, or process disclosed, or represents that its use would not infringe privately owned rights. Reference herein to any specific commercial product, process, or service by trade name, trademark, manufacturer, or otherwise does not necessarily constitute or imply its endorsement, recommendation, or favoring by the United States Government or any agency thereof. The views and opinions of authors expressed herein do not necessarily state or reflect those of the United States Government or any agency thereof. 


\section{DISCLAIMER}

Portions of this document may be illegible electronic image products. Images are produced from the best available original document. 


\title{
U.S. DEPARTMENT OF THE INTERIOR \\ BRUCE BABBITT, Secretary
}

\author{
U.S. GEOLOGICAL SURVEY \\ Gordon P. Eaton, Director
}

This report is preliminary and has not been reviewed for conformity with U.S. Geological Survey editorial standards (or with the North American Stratigraphic Code). Any use of trade, product, industry, or firm names is for descriptive purposes only and does not imply endorsement by the U.S. Government.

For additional information write to:

Chief, Earth Science Investigations Program

Yucca Mountain Project Branch

U.S. Geological Survey

Box 25046, MS 421

Denver Federal Center

Denver, CO 80225
Copies of this report can be purchased from: U.S. Geological Survey USGS Information Services Open-File Reports Section

Box 25286, MS 517

Denver Federal Center

Denver, CO 80225 


\section{CONTENTS}

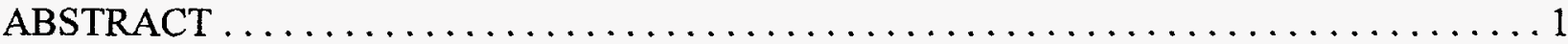

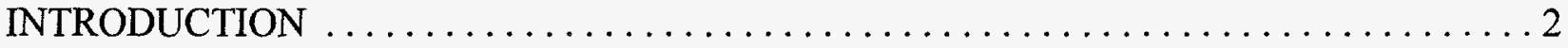

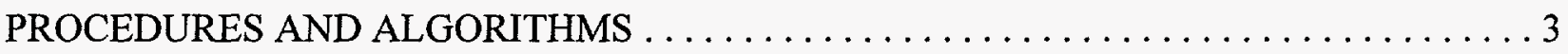

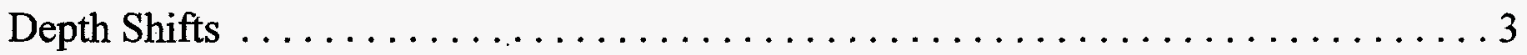

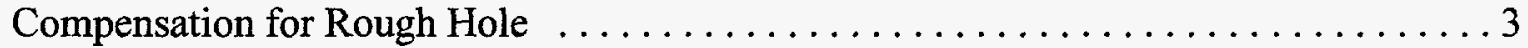

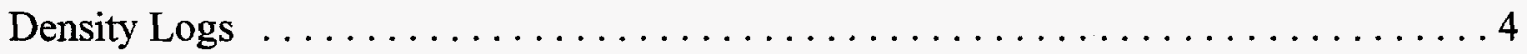

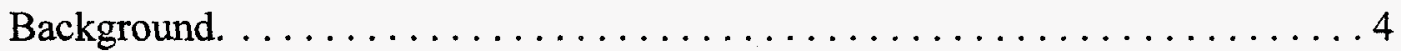

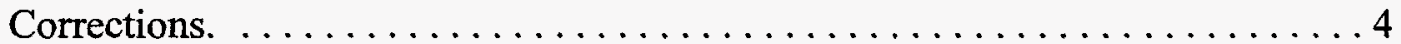

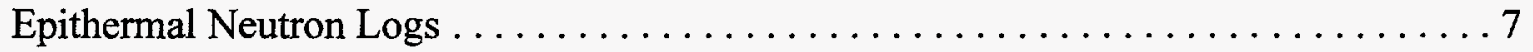

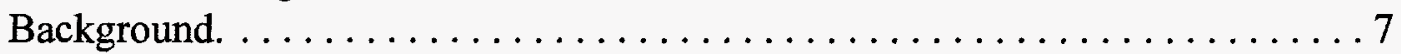

Operation of epithermal neutron tools. $\ldots \ldots \ldots \ldots \ldots \ldots \ldots \ldots \ldots \ldots . \ldots$

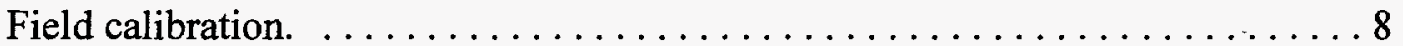

Response to water content, density, and hole size. $\ldots \ldots \ldots \ldots \ldots \ldots \ldots$

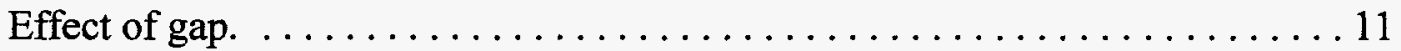

Methods for processing epithermal neutron logs. $\ldots \ldots \ldots \ldots \ldots \ldots \ldots 11$

Shortcomings of the Hydrogen Content Test Facility. . . . . . . . . . . 13

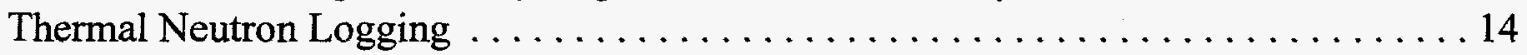

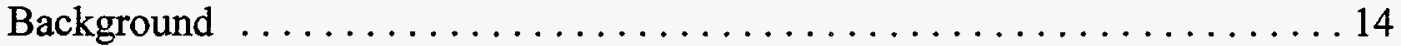

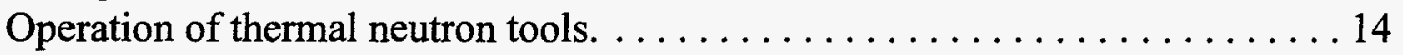

Correction for borehole effects. . . . . . . . . . . . . . . . . . . . 14

Excavation effect. . . . . . . . . . . . . . . . . . . . . . . . . . 15

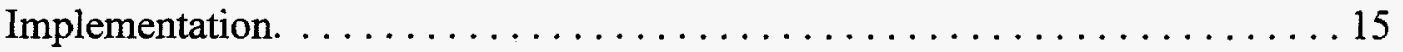

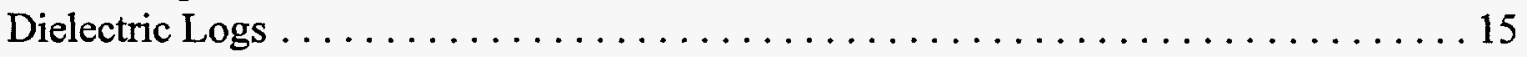

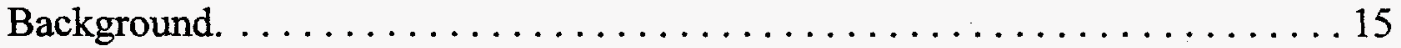

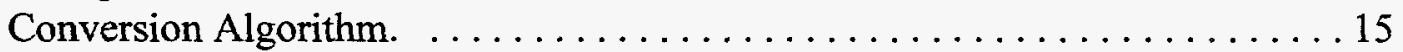

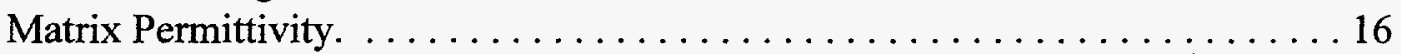

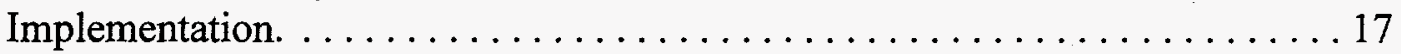

COMPUTATION OF POROSITY AND WATER CONTENT $\ldots \ldots \ldots \ldots \ldots \ldots \ldots \ldots . \ldots 17$

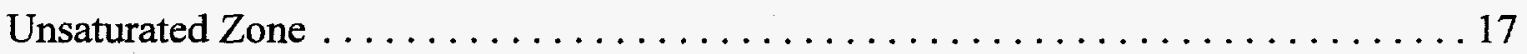

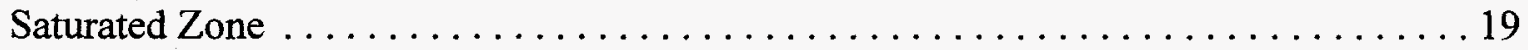

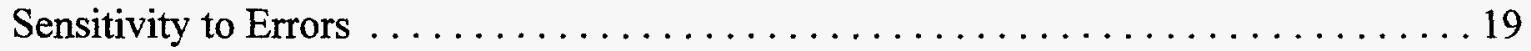

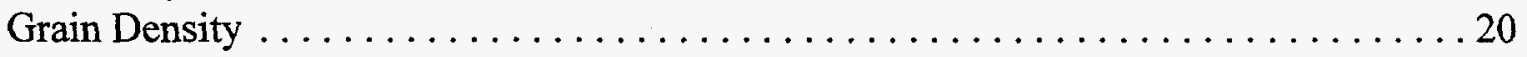

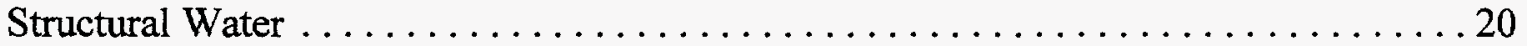

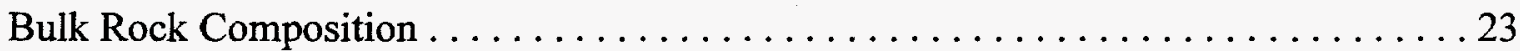

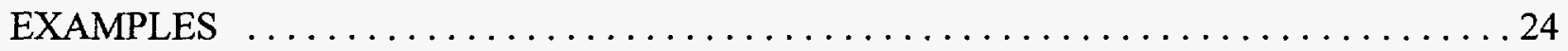

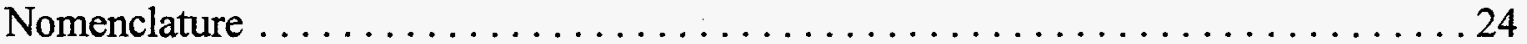

Example \#1, uncored borehole USW H-1, saturated zone ............... 24

Example \#2, uncored borehole USW H-1, unsaturated zone .............. 25 
Example \#3, cored borehole USW G-1, saturated zone $\ldots \ldots \ldots \ldots \ldots \ldots \ldots$

Example \#4, cored borehole USW G-1, unsaturated zone . . . . . . . . . . . 26

Example \#5, cored borehole USW G-2, zeolitic zone . . . . . . . . . . . . . 27

Example \#6, borehole USW WT-11, unsaturated zone $\ldots \ldots \ldots \ldots \ldots \ldots \ldots \ldots$

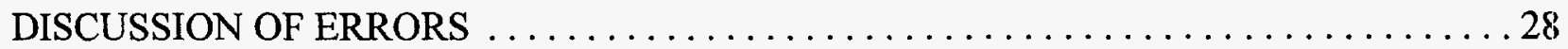

Comparison of $\log$-based computations with core measurements. $\ldots \ldots \ldots \ldots \ldots$

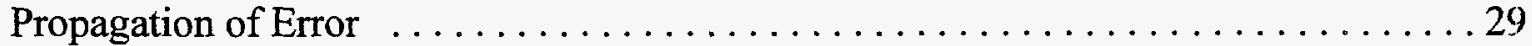

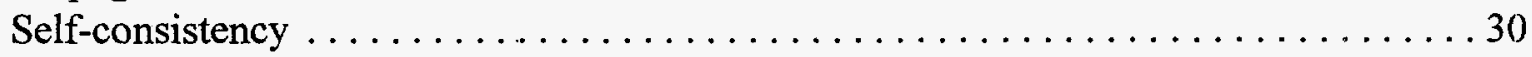

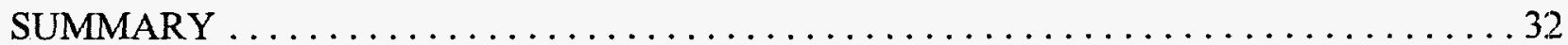

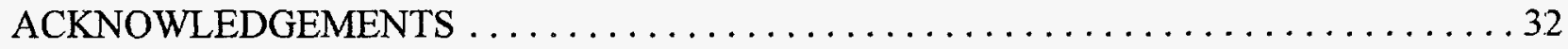

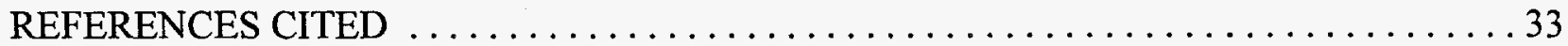

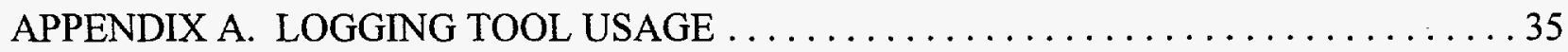

\section{FIGURES}

Figure 1. Map of borehole locations at Yucca Mountain, Nevada.........................................44

Figure 2. Overview of corrections and computations....................................................45

Figure 3. Borehole enlargements and response of density and neutron logs..........................4.6

Figure 4. Density measured by density $\log$ and in the laboratory, from the saturated zone.....47

Figure 5. Difference in density measured on core samples and logs vs. hole size...................48

Figure 6. Density from gravimeter tool vs. averaged gamma-gamma density values............49

Figure 7. Density from shifted gravimeter log vs. high-density bound from density tools.......50

Figure 8. Epithermal neutron $\log$ showing effect of gap...................................................51

Figure 9. Hydrogen index $I_{H}$ versus count rate from calibration facility................................52

Figure 10. Response curves for ENP tool \#193, computed from algorithm........................53

Figure 11. Neutron count rate versus water content for an epithermal neutron tool................54

Figure 12. Neutron count rate versus water content for unshielded ENP tools.......................55

Figure 13. Calibration of shielded tool \#32 in air-filled hole in two calibration facilities.......56

Figure 14. Difference between water contents determined in two calibration facilities..........57

Figure 15. Porosity and water content below static water level in borehole USW H-1..........58

Figure 16. Porosity and water content above static water level in borehole USW H-1..........59

Figure 17. Porosity and water content below static water level in borehole USW G-1.........60

Figure 18. Porosity and water content above static water level in borehole USW G-1..........61

Figure 19. Porosity and water content in borehole USW G-2 .........................................62

Figure 20. Porosity and water content above static water level in borehole USW WT-11......63

Figure 21. Computed porosity vs. core porosity in six intervals, for cases listed in table 9 ..........64 


\section{TABLES}

Table 1. Corrections applied to density and gravity logs, and computation of porosity .............7

Table 2. Coefficients for algorithm linking hydrogen index and density to count rate.............10

Table 3. Coefficients for polynomial linking count rate and density to hydrogen index...........10

Table 4. Conversions and corrections applied to epithermal neutron logs...................................13

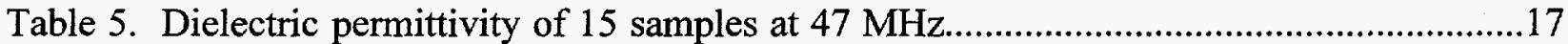

Table 6. Terms describing how water is held in zeolitic or clay-bearing rocks..........................21

Table 7. Chemical formula and neutron response for 15 minerals..........................................22

Table 8. Curve names for porosity, water content, and saturation computed from logs.............25

Table 9. Comparison of log-based and core-based values of porosity in four boreholes............29

Table 10. Uncertainty in computed porosity for four cases....................................................30

Table 11. Averages of porosity and water content in three boreholes........................................31

Table A1. Density sondes, panels, and sources used at Yucca Mountain, 1978-1984...............36

Table A2. Epithermal neutron tools run at Yucca Mountain, 1979-1984...................................38

Table A3. Field calibration data from tails of epithermal neutron logs......................................41

Table A4. Compensated neutron tools run at Yucca Mountain, 1980-1984 ...................................42

\section{CONVERSION FACTORS}

\begin{tabular}{|c|c|c|}
\hline $\begin{array}{l}\text { Multiply } \\
\text { centimeter }(\mathrm{cm}) \\
\text { meter }(\mathrm{m})\end{array}$ & $\begin{array}{l}\text { By } \\
0.3937 \\
3.281\end{array}$ & $\begin{array}{l}\text { To Obtain } \\
\text { inch (in.) } \\
\text { foot (ft.) }\end{array}$ \\
\hline
\end{tabular}




\title{
COMPUTATION OF POROSITY AND WATER CONTENT FROM GEOPHYSICAL LOGS, YUCCA MOUNTAIN, NEVADA
}

\author{
By Philip H. Nelson
}

\begin{abstract}
Neutron and density logs acquired in boreholes at Yucca Mountain, Nevada are used to determine porosity and water content as a function of depth. Steps in the calculation procedure include depth adjustment of logs, compensation for rough hole, and calibration, which incorporates the effects of tool type, borehole size, and borehole fluid. Depth adjustment is done by inspection of offsets and consideration of the logging history. Rough hole effects are reduced by splicing the logs across zones of hole enlargement. Calibration of the density $\log$ is based upon measurements of core samples. Calibration of the epithermal neutron logs, used primarily in air-filled holes in the unsaturated zone, is based upon specially constructed models of known density and water content. Calibration of thermal neutron logs, used primarily in water-filled holes in the saturated zone, relies on algorithms from the logging contractor.
\end{abstract}

Computation of porosity requires an estimate of grain density, which is provided by core data, mineralogical data, or is inferred from rock type where neither core nor mineralogy are available. The porosity estimate is merged with mineralogical data acquired by X-ray diffraction to compute the volumetric fractions of major mineral groups. The resulting depth-based portrayal of bulk rock composition is equivalent to a whole rock analysis of mineralogy and porosity.

Water content is computed from epithermal and thermal neutron logs. In the unsaturated zone, the density log is required along with a neutron log. Water content can also be computed from dielectric logs, which were acquired in only a fraction of the boreholes, whereas neutron logs were acquired in all boreholes. Mineralogical data are used to compute a structural (or bound) water estimate, which is subtracted from the total water estimate from the neutron-density combination. Structural water can be subtracted only from intervals where mineralogical analyses are available; otherwise only total water can be reported.

The algorithms and procedures are applied to logs acquired during 1979 to 1984 at Yucca Mountain. Examples illustrate the results. Comparison between computed porosity and core measurements shows systematic differences ranging from 0.005 to 0.04 . These values are consistent with a sensitivity analysis using uncertainty parameters for good logging conditions. Water content from core measurements is available in only one borehole, yielding a difference between computed and core-based water content of 0.006 . 


\section{INTRODUCTION}

Geophysical logs and measurements of physical properties on core have been acquired as holes are drilled to characterize Yucca Mountain, a potential site for the emplacement of radioactive waste. This report deals with data acquired during 1979-1984 in boreholes shown in figure 1. After this time period, about seven years elapsed before drilling and logging commenced again, with a different set of logging contractors and measurement laboratories than had been involved earlier. This second phase of data acquisition continues at the time of this report. Considering the changes in methodology and the usefulness of the older data for hydrological modeling, it is appropriate that the data from 1979-1984 be treated and analyzed as a separate data set.

Due to the size and complexity of the data set, the work and its reporting has been accomplished in three phases: compilation and editing, understanding log response, and deriving hydrological information from the data. The first phase, compilation and editing, was largely accomplished when logs and core data from forty boreholes were entered into a common data base (Nelson and others, 1991). Nelson and others (1991) describe the logging tools, the drilling procedures that affected log acquisition, the editing procedures, and outstanding characteristics of the logs.

Use of the logs requires an understanding of their response in terms of the physical properties of the volcanic tuffs which comprise Yucca Mountain, particularly in terms of the pore space and mineral content of the tuffs. Thus the second phase of work, understanding log response, was done by examining the core measurements in the context of geological description and mineralogical analyses. Nelson and Anderson (1992) and Nelson (1993a) show that porosity, a first-order control on $\log$ response, varies over a wide range in the tuffs, from as low as $1 \%$ in densely welded tuff to as high as $53 \%$ in zeolitized non-welded tuff. Almost as important as porosity in controlling log response is the alteration mineralogy. Zeolites and clays reduce the grain density, increase the electrical conductivity, reduce the compressional velocity, and reduce the matrix permeability. Concepts and expressions describing physical property variations in sedimentary rock were used to describe the tuffs.

The third and final phase of work uses the borehole logs and core data to compute parameters of interest to hydrological investigations. In particular, porosity and water content can be determined from a combination of density and dielectric logs (Nelson, 1993b) or from a combination of density and epithermal neutron logs (Nelson, 1994). Resistivity was much less promising because high resistivity in the unsaturated zone makes it quite difficult to reliably compute saturation and also compromises the quality of the induction log. Sonic logs could not be run in air-filled boreholes. This report builds upon the approaches developed in Nelson (1993b, 1994), focusing primarily upon the computation of porosity and water content from the density and epithermal neutron logs. The procedures are complicated by the need for calibration data in air-filled boreholes and by the usage of different models of density and neutron logging tools during the 1979-1984 time period (tables $\mathrm{A} 1$ and $\mathrm{A} 2$ ).

An overview of the computations is shown in figure 2. Boxes represent modules of Fortran code linked to the data base through commercial logging software. Modules ENPWATER and DIEL perform the computations to convert the processed density, epithermal neutron, and dielectric logs to total porosity, water content, and saturation. Module BOUND fits a smooth edge to the density and epithermal neutron logs where they have been corrupted by rough hole. Module RHOGZONE selects appropriate grain density values based upon zonation of the borehole into specified rock 
types. This report describes the development and application of algorithms depicted in the boxes of figure 2. Throughout this report, the names of computational modules are written in capital letters, while curve names are written in lower case italics. A curve is any information stored by depth and can be a geophysical log, a computed log, core data, or geological observations.

The procedures and algorithms described in the next section are applicable to the logs acquired in forty boreholes as presented by Nelson et al. (1991). Borehole coordinates are given in table 1 of Nelson et al. (1991) and locations are shown in figure 1 of this report. The computation of porosity and water content are treated in the third section, including a discussion of how mineralogical data are used to provide estimates of grain density and structural water. In turn, the porosity data are combined with mineralogy to provide a log of bulk rock composition. Six examples illustrate the computations of porosity and water content within the unsaturated and saturated zones. Errors are discussed by comparing computations to core measurements, by pursuing a propagation-of-errors approach, and by examining consistency from different computations.

\section{PROCEDURES AND ALGORITHMS}

\section{Depth Shifts}

Logs are shifted in depth using interactive software to connect correlative points. In cored wells, logs are shifted to core data, which are represented by core measurements, X-ray diffraction mineralogy, and lithologic boundaries. In both cored and uncored wells, wellbore enlargements registered by the caliper log provide good reference depths for aligning logs. Depth errors can be systematic, in which case an independently logged interval can be offset from others, or they can be incremental, that is, due to cable measurement errors or to tool sticking. Systematic depth errors are recognized by visual inspection and can usually be diagnosed by examining the logging history. If one $\log$, such as the caliper, is misaligned with respect to all others, then it can be depth shifted to match the others. Incremental depth errors are corrected by aligning correlative points, and the software apportions depth corrections between those correlative points. A depth offset of one or two feet between logs is of little concern, but offsets of more than two feet require adjustment. Each well requires separate consideration for depth shifts because the logging history differs from well to well.

\section{Compensation for Rough Hole}

In rough (rugose) boreholes, the face of a sidewalled tool can separate from the rock, producing a gap between the detector or source and the rock. For both neutron and density logging tools in air-filled boreholes, this gap results in excess counts reaching the detector. In the case of the density tool, excess counts result in low-density spikes on the log (figure 3), and for the neutron tool, excess counts result in spikes indicating low water content. The spikes on both density and neutron logs often occur where the caliper log indicates an increase in hole size (Fig. 2). Muller and Spengler (1989) first pointed out that the low-count edge on the density log provides an acceptable density estimate. Thus, a method of overcoming the gap problem is to find the low-count edges on the logs and use an interpolation scheme to form a bound to the log, thereby eliminating the excess counts. The interpolation technique used here, which finds local minima and joins them with cubicspline segments (Press and others, 1986, pp. 86-89), is implemented in module BOUND, and is applied to the density and neutron logs (figure 3 ). This technique contrasts with more standard 
methods.

Standard methods of correcting the density log for gap effect use measurements made with the tool placed on calibration blocks of known density and with varying gap. A solution algorithm to the gap measurements is then implemented to correct the long-spaced density reading (Head and Barnett, 1983; Schimschal, 1993). Another method by Carlson (1993) uses a statistical method to compute the correction, based upon the standard deviations of the short-spaced and long-spaced measurements. The corrections required in the air-filled boreholes are large due to high rugosity. Density corrections made by the logging companies were not always available to us. Because of these difficulties, the spline-fit method implemented in BOUND was used for the density log and also for the single-detector epithermal neutron log.

\section{Density Logs}

Background. Density logs were routinely obtained at Yucca Mountain with "gamma-gamma" logging tools which emit and detect gamma radiation. In water-filled boreholes within saturated rock, log quality is generally good and the standard calibrations obtained from blocks of known density are applicable. Moreover, density measurements on core samples from the saturated zone are accurate because lithophysae are not present in the saturated zone and samples can be resaturated in the laboratory thereby circumventing possible loss of pore fluid. With both core and $\log$ measurements of good quality, agreement between the two is quite good in the saturated zone (Muller and Spengler, 1989). Final corrections, which were found to be negligible or small, are performed by comparing density logs to core measurements on a point-by-point basis.

However, in rough air-filled boreholes, the logs must be corrected and adjusted to a calibration standard. Calibration of the density tools in calibration blocks was inadequate, as discussed in the preceding section. Core measurements are not satisfactory as a standard in the unsaturated zone because core does not adequately sample the lithophysae and because the in-situ saturation state can be altered in the drilling and sampling process. In addition, gaps invalidating the log measurements can occur where core measurements exist, making it impossible to compare the two. Another method had to be found to correct the gamma-gamma density logs in the unsaturated zone.

Corrections. An approach used by Muller and Spengler (1989) to correct the gravimeter-based density measurements was adopted here and extended to correct the density logs in the unsaturated zone. First, the saturated-core measurements are used as exact measurements. Then the density logs in the saturated zone are adjusted, where necessary, to the core data. Next, the gravimeter is corrected to the gamma-gamma density logs. And lastly, gamma-gamma density logs in the unsaturated zone are corrected to the gravimeter-based values.

The procedure, which was followed in this work for each of the different density tools, consists of three steps:

1. Compare the gamma-gamma density log to core-derived density values within the saturated zone. Establish and apply a correction to the gamma-gamma density log, if needed.

2. Compare gravimeter-derived density values to the corrected gamma-gamma density log values, averaged over comparable intervals within the saturated zone. Although the gravimeter is unaffected by rough hole, it is subject to uncertainties in terrain corrections and in the free-air 
correction. Establish a correction for the gravimeter-derived density values. Apply the correction to the gravimeter-derived density values in both the saturated and unsaturated zones.

3. Compare the corrected gravimeter-derived density values to gamma-gamma density log values in the unsaturated zone. Instead of the original density log, use the low-count, high-density bound averaged over the gravimeter intervals. Establish a correction to apply to the gamma-gamma density logs in the unsaturated zone.

The following paragraphs describe the implementation of this three-step procedure.

Density measurements were available for samples from seven boreholes: UE-25a\#1, USW G-1, G-3, G-4, UE-25b\#1, USW H-1, andUE-25p\#1. Because log quality and calibrations are generally good in water-filled boreholes, we expect good agreement between the density logs and density measured on samples in the saturated zone. Density log data were selected from the depth at which core samples were taken, without depth shifts. Some depth intervals were omitted, such as the zones in USW G-4 where air invasion during drilling caused anomalously low density log readings (Nelson and others, 1991). Further culling was done by dropping all points outside $\mathrm{a} \pm 0.05$ $\mathrm{g} / \mathrm{cm}^{3}$ bound on a linear least-squares fit to all the data. The resulting correlations are shown in figure 4.

Good agreement between core samples and log values were obtained in boreholes UE-25b\#1 and USW H-1 (figure 4), both of which were logged with the Birdwell tool. No correction is required for these logs in the saturated zone. However, in boreholes in which the AWS 2208 tool was used, the density log is biased high at low densities (figure 4). The data from USW G-1, G-3, and G-4 were composited and a y-on-x regression fit of $d b c$ to $s b d$ produced the equation,

$$
d b c 1=1.142 * d b c-0.320
$$

This correction was applied to logs run with Atlas Wireline tools. The correction is less than 0.02 $\mathrm{g} / \mathrm{cm}^{3}$ for $\log$ values between 2.15 and $2.40 \mathrm{~g} / \mathrm{cm}^{3}$. The correction is unconstrained at density values less than $1.9 \mathrm{~g} / \mathrm{cm}^{3}$, and hence is a potential source of error in low-density rock.

The tightly clustered data from UE-25p\#1 are from dolomite. Many points come from a brecciated zone where it is not surprising that the density log would record a lower density than a core sample. Because of the limited range of density values, no fit was applied.

Do density log values depend upon borehole diameter? Within the saturated zone, this question is addressed by plotting the difference between core sample data and density log values against hole diameter (figure 5). The data show no apparent dependence upon hole diameter. Consequently, no correction for hole size is required for density logs in water-filled boreholes. The plot does show a large difference between core and log data for borehole UE-25a\#1, which was logged with an older Birdwell tool. This tool, not used at Yucca Mountain other than in borehole UE-25a\#1 (Table A1), does require a calibration correction, but the data are not adequate to show whether or not a hole-size correction is required. Within the unsaturated zone, core samples do not adequately sample the formation because lithophysal cavities are present. Consequently, a hole-size correction could not be assessed. The lack of such a correction could lead to an underestimate of density and an overestimate of porosity in large-diameter, air-filled boreholes (see Discussion of Errors).

The second step in density log correction requires a comparison between the gravimeter data and gamma-gamma density log values averaged over the intervals commensurate with the 
gravimeter data (figure 6). Gravimeter data in the saturated zone were available from boreholes UE$25 \mathrm{c} \# 1$, USW H-1,UE-25p\#1, and USW G-4. Procedures and references are given by Healey et al. (1986). Core data were not generally available in these four boreholes, so the gravimeter data were compared to density log data rather than directly to core data. Zones where air invasion occurred in USW G-4, and also where density data were obviously flawed, were eliminated from the comparison. Regression fits for each well showed that the data from the four holes were quite comparable and that a single fit to all the data would suffice. As a consequence, the transform

$$
g r a v \_s h=1.054^{*} \text { grav }-0.174
$$

was applied to gravimeter logs, resulting in a decrease of 0.07 to $0.02 \mathrm{gm} / \mathrm{cm}^{3}$ over the range 1.9 to $2.8 \mathrm{gm} / \mathrm{cm}^{3}$. A constant offset of the gravimeter data from the density log would be expected if all the error were due to an error in the free-air gradient. Terrain-correction errors could cause the density-dependent correction in equation 2 . Terrain corrections are greatest high in the borehole, where densities are relatively low, than at depth, where densities are relatively high.

The third step in the procedure ties the density log in the unsaturated zone (air-filled borehole) to the corrected gravimeter log. Logs from boreholes USW GU-3, G-4, UE-25c\#1, and USW H-1 were used in this step. Because the low-count, high-density bound would be used to compute porosity, the high-density bound was first determined from the density log, using the spline procedure encoded in BOUND. Then the gravimeter data were compared with the average of the high-density bound from the same interval. Pairs of points were dropped from the data set where extreme washouts or low-to-high density transitions dominated the interval. Examination of the data showed that a) the three AWS tools, (models 2207, 2208, and 2212) each differed from the shifted gravity log and from each other, b) once this tool dependence was recognized, there was little or no hole-size dependence, and c) the Birdwell model 8001, serial 6 and 12, tools were similar and matched the shifted gravimeter log more closely than the AWS logs. Consequently, using a y-on-x fit of the shifted gravimeter data to the averaged density bound (figure 7), four corrective equations were determined for the four tools. The corrections are substantial. For example, a density of 2.00 $\mathrm{g} / \mathrm{cm}^{3}$ read by a model 8001 tool will correct to a value of $1.95 \mathrm{~g} / \mathrm{cm}^{3}$, and will correct the fractional porosity by +0.02 . The equations given in figure 7 were applied to the density bound in the unsaturated zone, according to tool type. The Birdwell model 8001 series, which were run in more boreholes than the AWS tools, required less correction than the AWS tools (Table 1). 


\begin{tabular}{||l|l|l||}
\hline \hline \multicolumn{3}{||l}{$\begin{array}{l}\text { Table 1. Summary of corrections applied to density and gravity logs, and computation } \\
\text { of porosity. }\end{array}$} \\
\hline TOOL & SATURATED ZONE & UNSATURATED ZONE \\
\hline BW 8001 & No correction. & $\begin{array}{l}\text { dbcair }=1.008^{*} d b c b n d-0.0646 \\
\text { DENAIR }\end{array}$ \\
\hline AWS 2207 & $\begin{array}{l}d b c l=1.142 * d b c-0.320 \\
\text { EQUUS }\end{array}$ & $\begin{array}{l}\text { dbcair }=0.981^{*} d b c b n d-0.0578 \\
\text { DENAIR }\end{array}$ \\
\hline AWS 2208 & $\begin{array}{l}d b c l=1.142^{*} d b c-0.320 \\
\text { EQUUS }\end{array}$ & $\begin{array}{l}\text { dbcair }=1.038^{*} d b c b n d-0.194 \\
\text { DENAIR }\end{array}$ \\
\hline AWS 2212 & $\begin{array}{l}d b c l=1.142^{*} d b c-0.320 \\
\text { EQUUS }\end{array}$ & $\begin{array}{l}\text { dbcair }=0.815^{*} d b c b n d+0.428 \\
\text { DENAIR }\end{array}$ \\
\hline Gravimeter & $\begin{array}{l}\text { grav sh } s=1.054^{*} \text { grav }-0.174 \\
\text { EQUUS }\end{array}$ & $\begin{array}{l}\text { grav_sh }=1.054 * g r a v-0.174 \\
\text { EQUUS }\end{array}$ \\
\hline Porosity & $\begin{array}{l}\phi_{\mathrm{t}}=\left(\rho_{\mathrm{g}}-\rho_{\mathrm{b}}\right) /\left(\rho_{\mathrm{g}}-\rho_{\mathrm{w}}\right) \\
\text { DENPOR }\end{array}$ & $\begin{array}{l}\phi_{\mathrm{t}}=\left(\rho_{\mathrm{g}}-\rho_{\mathrm{b}}+\rho_{\mathrm{w}} \phi_{\mathrm{w}}\right) / \rho_{\mathrm{g}} \\
\text { ENPWATER, DIEL }\end{array}$ \\
\hline
\end{tabular}

\section{Epithermal Neutron Logs}

Background. Neutron logs are an effective means of measuring water content because energetic neutrons are slowed down by hydrogen nuclei, and most hydrogen occurs in water. Hearst and Nelson (1985) define the hydrogen index $I_{H}$ as the volume fraction of fresh water that would contain the same amount of hydrogen. In a rock of porosity $\phi$ and saturation $S_{w}$, containing fresh water and no other hydrogen, $\mathrm{I}_{\mathrm{H}}=\phi \mathrm{S}_{\mathrm{w}}=\phi$. The nomenclature $\mathrm{H}_{\mathrm{H}}$ is used here to retain the distinction between the logging measurement $I_{H}$ and the rock property $\phi_{w}$.

Epithermal neutron detectors are shielded and respond to neutrons in the energy range 0.1 $\mathrm{eV}$ to $1.0 \mathrm{keV}$, whereas thermal neutron detectors respond primarily to neutrons with energies less than $0.1 \mathrm{eV}$. The epithermal measurement is considered more desirable than the thermal log because a few elements absorb thermal neutrons quite readily, thereby perturbing $I_{\mathrm{H}}$. Epithermal neutron logs are of particular importance at Yucca Mountain, because they can be operated in air-filled boreholes whereas the thermal neutron tools require that the hole be filled with water.

The Birdwell epithermal neutron (ENP) tool used for the Yucca Mountain Project (YMP) was in service for the containment program at Nevada Test Site (NTS) during the 1970s. All epithermal neutron tools run in the YMP boreholes from 1979 through 1984 were Birdwell tools of the LABE-6001 model series (table A2) and are referred to as the ENP (epithermal neutron porosity). From 1979 until February 1982, tools designated as Z-145 and Z-193 were used. Then the tool electronics were modified, designated as "mod 4". From March 1982 until the last log in UZ-6 was run in June 1984, four tools bearing the serial numbers 16, 20,21, and 23 were run with the modified electronics. Most of the holes were logged with tool number 21 or 23. 
Operation of epithermal neutron tools. The ENP sonde incorporates an epithermal neutron detector and a source of neutrons on a sidewall pad. In operation, the pad is pressed against the wall of the borehole. Shields loaded with borated polyethylene were developed to reduce the neutron flux coming from the back side of the tool in an air-filled borehole. Some log headers note that a shield was used and some note that no shield was used, but most headers do not tell whether or not one was used (table A2). With the shield, the tool diameter was about 6 inches so it could not be used in hole sizes less than about 9.5 inches (R. Carlson, Lawrence Livermore National Laboratory, oral communication, 1993). The shields were not intended for use in water-filled boreholes. A shield probably reduces the hole size effect, although there are no data on tool response as a function of hole size to confirm this.

To increase the pressure on the tool face, an extra skid could be added to the arm on the back side of the tool. The skids were intended to be used in larger boreholes, on the order of 17 inches in diameter. However, apparently the skids were also used in 8-3/4 inch holes (table A2). The presence of a skid is not expected to affect the tool response.

The ENP was run with a proximity wheel which measured the distance (gap) between the face of the tool and the borehole wall. The wheel had a range of 0 to 1 inch (figure 8). The portion of the ENP tool containing source and detector is roughly three feet in length, corresponding with the maximum vertical extent of proximity openings which extend for 2 to 4 feet. Note the correlation between the gap and increased counting rate (API units) in figure 8. In an air-filled borehole, a gap between the detector and the borehole wall permits more neutrons to reach the detector, resulting in higher counting rate and erroneously lower estimates of water content.

Field calibration. Field calibration of the epithermal tool was done before and after a logging run and recorded on the tail of the log. The tool is placed in a fixed position inside a polyethyene block. Both the source and detector lie within the block. Two drawers or "baffles" can be raised or lowered to give three calibration points: both baffles up (BBU), both baffles down (BBD), and one baffle up (1BU or OBU). Each point is assigned a value in American Petroleum Institute (API) units. Counts obtained on a logging run were scaled to API units by multiplying the measured count rate by the ratio of the API value for both baffles up to counts obtained with both baffles up (last column in table A3). The ratio of counts to API units from the other two positions are recorded to assess linearity. The logging company converted each $\log$ from counts to API units. Data from before each run are given in table $A 3$, sorted by tool number, and by date of the logging run. Table $A 3$ serves as a record of tool-to-tool variability and the long-term stability of individual tools.

The API values assigned to a calibration block are linked to the API test pits in Houston. The API test pits contain a water-filled borehole of 7-7/8 inch diameter into a block of Indiana limestone of $19 \%$ porosity, which is assigned a value of 1000 API units. A counting rate obtained in a calibrator is assigned an API unit proportional to the counting rate obtained at 1000 API units, and thus serves as a counting rate reference. If counting rate should vary for some reason, such as radioactive decay of the source, then the calibrator provides a means of correcting the observed counting rate.

Most logging companies no longer use the API neutron standard, preferring to present their results directly in "limestone porosity" units, based upon results from their own calibration facilities. However, the Birdwell epithermal logs are presented in API units and algorithms converting log response to water content were developed using API units. 
Response to water content, density, and hole size. The relationship between tool response, whether expressed in API units or counting rate, and water content depends upon hole size, borehole fluid, rock type, and rock density. The first two effects were addressed by the contractor (Birdwell): hole size, ranging from 4 to 12 inches, appears as a parameter on charts relating API units to porosity. Separate charts were constructed by Birdwell for air-filled and water-filled boreholes in uncased holes in limestone. These charts were hand digitized for use in our analysis; the chart for an airfilled hole is shown in figure 9. These tool calibrations by Birdwell were done without the shields, which were later built and used at NTS and in a few holes at Yucca Mountain.

Requiring calibration in very large boreholes used for weapons testing, Hearst (1979) and Hearst and others (1981) developed a Hydrogen Content Test Facility (HCTF) constructed of aluminum boxes containing alumina, silica, and water. Twelve cells provide 12 mixtures of density and water content spanning the ranges of 0.85 to $2.64 \mathrm{~g} / \mathrm{cm}^{3}$ and 0 to $100 \%$ water volume. The HCTF provides a flat wall to simulate the very large boreholes and an empty $30-\mathrm{cm}$ square column simulating a $30-\mathrm{cm}$ borehole. Calibrations were made in the HCTF during the time that logging was carried out at Yucca Mountain.

Using the HCTF calibrations to compute water content has four advantages for our work. First, calibrations on tools 20,21, and 23 were made in the HCTF during October 1983 through May 1984, and so are appropriate for much of the logging at Yucca Mountain during the 1979-1984 time period. Second, the calibrations were done on materials chemically similar to the tuffs, so that no additional transform to account for rock type dissimilarites is required. Third, the calibration cells are partially saturated, so air is present in the calibration media and does not require separate accounting. Fourth, the calibration cells and resulting algorithms incorporate the effect of varying density, which does affect the relationship between counting rate and water content, particularly at water contents below $20 \%$.

The algorithms pertinent to our application were developed and published in two stages. An algorithm developed by Hearst and others (1981) for zero gap is,

$$
y=\ln (N)=\alpha_{1}\left(1+\alpha_{2} \rho\right) \exp \left(\alpha_{3} \mathrm{I}_{\mathrm{H}}\right)+\alpha_{4}
$$

where $\mathrm{N}$ is the measured count rate (API units), $\rho$ is the density, $I_{H}$ is hydrogen index, and $\alpha_{i}$ are coefficients determined by fitting the function to the calibration data. In our application, equation 3 was used only for unshielded tools. The $\alpha_{i}$ coefficients for two tools, shielded and unshielded, are listed in table 2.

A second algorithm developed by Axelrod and Hearst (1984) for zero gap is

$$
I_{H}=\beta_{0}+\beta_{1} y+\beta_{2} y^{2}+\beta_{3} \rho+\beta_{4} \rho y
$$

where $y=\ln (N), N$ is the measured count rate (converted to API units), $\rho$ is the density, and $\beta_{i}$ are coefficients determined by fitting a function to the calibration data. Note that equation 4 predicts $I_{H}$ for a given $y$ and $\rho$, whereas equation 3 predicts $y$ for a givenn $I$ and $\rho$. In our application, equation 4 is applied only to shielded tools; the $\beta_{i}$ coefficients for several tools and shields are listed in table 3 . Shield 2 is the same as the "green shield" listed in table A2. 


\begin{tabular}{||l|l||}
\hline $\begin{array}{l}\text { Table 2. Coefficients } \alpha_{1}, \ldots, \alpha_{4} \text { for algorithm linking hydrogen index and density to } \\
\text { count rate, obtained in } 12 \text {-inch square hole in HCTF, } 5 \text { May 1980, for tools } 145 \text { and } \\
\text { 193. From R. C. Carlson, written communication, 1993. }\end{array}$ \\
\hline \multicolumn{2}{|c|}{ LABE-6001/145 } \\
\hline air-filled, unshielded & $1.245000,0.301840,-2.901400,7.401900$ \\
\hline air-filled, shielded & $2.595500,0.025043,-2.790300,6.284900$ \\
\hline water-filled, unshielded & $3.743900,-0.069247,-2.787800,5.259700$ \\
\hline water-filled, shielded & $3.623700,-0.073897,-3.237000,5.600500$ \\
\hline & LABE-6001/193 \\
\hline air-filled, unshielded & $1.330200,0.272020,-2.867500,7.327900$ \\
\hline air-filled, shielded & $2.580000,0.036948,-2.619800,6.198200$ \\
\hline water-filled, unshielded & $3.790700,-0.069009,-2.896000,5.245900$ \\
\hline water-filled, shielded & $3.308900,-0.044556,-2.745900,5.494500$ \\
\hline
\end{tabular}


The effects of shielding and borehole fluid upon tool response can be demonstrated from the calibration results. The curves in figure 10 were computed from equation 3 using a density of $2.0 \mathrm{~g} / \mathrm{cm}^{3}$ and coefficients established from calibration of tool 193 in the HCTF. First note that counting rate, displayed on a logarithmic scale, drops monotonically with increased $\mathrm{I}_{\mathrm{H}}$, as increased hydrogen content moderates more and more neutrons, preventing them from reaching the detector. Next, selecting any fixed value of water content, note that count rate drops from the highest counts of the unshielded-dry case to the lowest counts of the unshielded-wet case. This decrease occurs as more and more hydrogen is added within the borehole, first in the form of shielding, then in the form of shielding plus water, and finally in the form of a water-filled borehole (water presumably has a higher hydrogen density than the shield).

A second example of tool response is based upon equation 4 (figure 11). The coefficients are for the fourth tool/shield combination listed in table 3. As already noted, for a given water content, the count rate is much higher in an air-filled hole than in a water-filled hole. Density variations produce a much greater percentage change in count rate in a water-filled hole than in an air-filled hole (three different density lines are indistinguishable on the air-filled curve). Because equations 3 and 4 are different analytical expressions fitting empirical data, they produce different curve shapes (compare figures 10 and 11 ). For water content greater than 0.4 , the tool response functions are poorly constrained.

Effect of gap. Because of borehole rugosity, the tool face is not always flush with the wall of the hole. The spacing between the face of the tool and the wall is called the gap. Axelrod and Hearst (1984) found that count rate increases linearly with gap when the tool is in an air-filled borehole and that the rate of increase is a function of density and water content. They developed an algorithm that accounts for the effect of gap; their algorithm was not used for several reasons. First, the gap (proximity log) data were not read from the original field tapes into the YMP borehole data base. Second, the proximity wheel saturates at one inch, although gap often exceeds one inch. Third, the character of the proximity and ENP records differ (figure 8), so that application of the gap correction is not straightforward. Instead of directly compensating for gap, the left-hand edge of an ENP log from an air-filled hole was assumed to represent an envelope of zero-gap response. This assumption is justified by close inspection of records such as figures 3 and 8. It is similar in concept to the approach already discussed for the density log. Thus, for computational purposes, the ENP $\log$ is replaced by a second $\log$ (figure 3 ) formed by finding local minima and joining them with cubic-spline segments (Press and others, 1986, pp. 86-89).

In a water-filled borehole, any gap between the tool face and the borehole wall is filled with water. As a result, a gap produces a low count rate and an artificially high $\mathrm{I}_{\mathrm{H}}$. Thus the situation is reversed from that in an air-filled hole, and the envelope of zero-gap response lies on the high count side rather than on the low count side.

Methods for processing epithermal neutron logs. Having dispensed with the issue of gap, the next issue is the computation of water content from the ENP logs collected at Yucca Mountain using the Birdwell LABE-6001 series of logging tools. The treatment is more complicated for unshielded tools than for shielded tools.

Unshielded tools. In holes where an unshielded tool was run, both hole size and density must be accounted for. Density corrections for one hole size were obtained in the HCTF. Count rate as 
a function of $I_{H}$ and density for tools 145 and 193, unshielded, in the 12-inch square hole in the HCTF, both air- and water-filled, is given in equation 3 and table 2. The expressions and coefficients are summarized in table 4 . The response curves of tools 145 and 193 are quite similar one to another for water content in the 0.0 to 0.4 range, and are also quite comparable to tool 21 (figure 12). Because no calibration exists for tools 21 or 23 operated unshielded in air, a log recorded with tool 21 or 23 in those conditions was transformed using the response of tool 145 . Then, a correction derived from calibration of shielded tools in air was applied to the resulting $I$ ${ }_{\mathrm{H}}$ for tools 21 and 23 ; these corrections are designated $\mathrm{f}_{21}$ and $\mathrm{f}_{23}$ in table 4 .

Curves of $I_{H}$ as a function of hole size and count rate in uncased holes in limestone were obtained by Birdwell. These calibrations were obtained for unshielded tools in both air- and water-filled holes. The curves were used to account for hole size variations by using the caliper $\log$ in the computations. Computing a bound for the neutron and density logs effectively removes high-count responses where the borehole is enlarged. To avoid overcompensation in these washouts, a bound is also applied to the lower side of the caliper log before it is used to compute water content (calbnd, in figure 2).

The computational procedure for an unshielded tool in an air-filled hole, indicated on figure 9 where tool 193 serves as an example, merges the HCTF calibration with the hole size correction:

a. Given the enp count rate and the density from logs, calculate the water content $\mathrm{f}_{\mathrm{f}} \mathrm{using}$ equation 3.

b. Given the enp count rate, calculate the $I_{H}$ value according to the Birdwell chart for a 12-inch air-filled hole (uppermost of dashed curves in figure 9). Find the difference $\Delta \mathrm{l}_{\mathrm{H}}$ between the $I_{H}$ values determined for steps a and $b$.

c. Using the enp count rate and the hole size from the caliper log, calculate values of $\mathrm{I}_{\mathrm{H}}$ for the hole size curves bounding the hole size from the caliper log. Add $\Delta \mathrm{I}_{\mathrm{H}}$ to each of the $\mathrm{I}_{\mathrm{H}}$ values. The addition of $\Delta \mathrm{I}_{\mathrm{H}}$ has the effect of shifting the hole-size curves upwards so that the 12-inch curve overlies an HCTF-calibration curve of given density.

d. Using the hole size from the caliper $\log$ and the two values of $\mathrm{h}_{\mathrm{H}}$ from step $c$, interpolate between the hole size curves to obtain a final value of $I_{H}$.

For the case of an unshielded tool in a water-filled borehole, hole-size corrections are important but were not done because the thermal (compensated) neutron logs were available and provided good results. Conversion of the epithermal count rate to porosity without hole-size correction provided an approximate porosity log, which was used occasionally to compare with the porosity logs derived from the thermal neutron and density logs in the saturated zone.

Shielded tools. $I_{H}$ as a function of count rate and density for tools 20,21 , and 23 , shielded, in the 12-inch square hole in the HCTF, both air- and water-filled is given by equation 4 and table 3 , and is summarized in table 4 .

A shield was used in only six of the boreholes: UE-25c\#1, C-2, C-3,UE-25p\#1, UZ-1, and UZ-6, which were logged with tools 21 and 23 (table A2). Calibration information for these tools, with shields, incorporates density dependence, but there are no calibration data for varying hole size. In water-filled boreholes, a hole-size dependence is expected to be minimal, but in airfilled holes, significant errors could arise. 


\begin{tabular}{|c|c|c|}
\hline TOOL & SATURATED ZONE & UNSATURATED ZONE \\
\hline \multicolumn{3}{|c|}{$\begin{array}{c}\text { Unshielded } \mathrm{y}=\alpha_{1}\left(1+\alpha_{2} \rho\right) \exp \left(\alpha_{3} \mathrm{I}_{\mathrm{H}}\right)+\alpha_{4} \\
\text { where } \mathrm{y}=\ln (\text { enpbnd }) \text { or } \ln (\text { enp })\end{array}$} \\
\hline 145 & $\alpha-145$, water & $\alpha-145$, air, caliper \\
\hline 193 & $\alpha-193$, water & $\alpha-193$, air, caliper \\
\hline 21 & $\begin{array}{l}\alpha-145, \text { water, } \\
\mathrm{I}_{\mathrm{H}}^{\prime}=0.90 * \mathrm{I}_{\mathrm{H}}\end{array}$ & $\begin{array}{l}\alpha-145, \text { air, caliper, } \\
\mathrm{I}_{\mathrm{H}}^{\prime}=\mathrm{f}_{21}\left(\mathrm{I}_{\mathrm{H}}\right)\end{array}$ \\
\hline 23 & $\begin{array}{l}\alpha-145, \text { water, } \\
\mathrm{I}_{\mathrm{H}}^{\prime}=0.73 * \mathrm{I}_{\mathrm{H}}\end{array}$ & $\begin{array}{l}\alpha-145, \text { air, caliper, } \\
\mathrm{I}_{\mathrm{H}}^{\prime}=\mathrm{f}_{23}\left(\mathrm{I}_{\mathrm{H}}\right)\end{array}$ \\
\hline \multicolumn{3}{|c|}{$\begin{array}{cc}\text { Shielded } & I_{\mathrm{H}}=\beta_{0}+\beta_{1} \mathrm{y}+\beta_{2} \mathrm{y}^{2}+\beta_{3} \rho+\beta_{4} \rho \mathrm{y} \\
\text { where } \mathrm{y}=\ln (\text { enp }) \text { or } \ln (\text { enpbnd })\end{array}$} \\
\hline 20 & $\beta$-20, water & $\beta-20$, air \\
\hline 21, shield 1 & $\beta-21 / 1$, water & $\beta-21 / 1$, air \\
\hline 21, shield 3 & $\beta-21 / 3$, water & $\beta-21 / 3$, air \\
\hline 23 & $\beta-23$, water & $\beta-23$, air \\
\hline
\end{tabular}

Shortcomings of the Hydrogen Content Test Facility. Using a Monte Carlo code to simulate the ENP tool in the HCTF, Deupree and Noel (1988) determined that the calibration facility gives erroneously low results at low water contents. They attributed the error to the presence of water in cells assumed to have zero water content. They also found that the error was larger at low bulk densities $\left(<2.0 \mathrm{gm} / \mathrm{cm}^{3}\right)$ than at high bulk densities. And finally, they found that at water mass fractions of 0.15 and less, a hole-size correction was needed for the very large holes used in weapons testing. Although valid, these concerns did not much affect the YMP data and have not been addressed in this report. Another problem with the HCTF more seriously affected the YMP data.

The HCTF was built with a 30-cm square hole in which most of the epithermal tools used at Yucca Mountain were calibrated. The curvature of the tool face resulted in a curved gap when the tool face was placed against the wall of the square hole, resulting in higher count rates than would occur if the tool were calibrated in a round hole. To overcome this and other shortcomings, a second facility called the Hydrogen Content Test Unit (HCTU) was constructed (Hearst, 1994). Tool \#32 was calibrated in an air-filled hole in both facilities. A tool calibrated in the HCTF will provide a water content measurement greater than a tool calibrated in the HCTU, and the overestimate increases with increasing water content, that is, with decreasing count rate (figure 13). The data from tool \#32 were used to obtain a final correction algorithm which was applied to logs obtained in air-filled holes (figure 14). The correction, shown in figure 14, is 


$$
\Delta \mathrm{I}_{\mathrm{H}}=0.383 \mathrm{I}_{\mathrm{HF}}^{2}+0.131 \mathrm{I}_{\mathrm{HF}}-0.0125
$$

where $\mathrm{I}_{\mathrm{HF}}$ is the water content (strictly speaking, the hydrogen index) based on a calibration obtained in the HCTF. Because the HCTF calibration causes an overestimate of water content, the corrected value of $I_{H}$ is,

$$
\mathrm{I}_{\mathrm{HU}}=\mathrm{I}_{\mathrm{HF}}-\Delta \mathrm{I}_{\mathrm{H}}
$$

Computed water content logs presented by Nelson (1994) will differ somewhat from results of this report because the former lack the correction shown in equations 5 and 6 .

Computations for the epithermal tools, including the correction to HCTU-based values, were coded into module ENPWATER (figure 2).

\section{Thermal Neutron Logging}

Background. Both Birdwell and Dresser Atlas thermal neutron tools were used to log boreholes at Yucca Mountain (table A4). Unlike the epithermal neutron tools, thermal neutron tools were not used by the containment program at NTS, hence no calibration history exists for the thermal neutron tools at NTS. Dresser Atlas tool models were either the 2413 (3.625-inch diameter) model or the 2418 (2.75-inch diameter) model. Model 2413 has the same specifications and response function as the Dresser Atlas model 2420 (Bill Mountjoy, Atlas Wireline Services, oral communication, 1994). Correction charts for the 2413 and 2418 are given by Dresser Atlas (1985). Birdwell tools were either the LAGA-8001 or LAGC-8001; correction charts are given by Birdwell (1983). Thermal neutron logs are designated "NBC" (neutron - borehole compensated).

Operation of thermal neutron tools. The tools contain two detectors of neutrons that have been "thermalized", that is, brought into equilibrium with the formation temperature. Logs from these tools are often referred to as "compensated neutron logs" because the dual-detector systern provides compensation for borehole rugosity. As described in Nelson and others (1991), the tools are run decentralized with a bowspring that forces the mandrel against the side of the borehole. Logs are scaled in "neutron porosity" units, which represent the porosity of one of three waterfilled sedimentary rocks - sandstone, limestone, or dolomite. Most logs examined in this report were acquired on a sandstone scale, a lithology judged to be closest to volcanic tuffs in terms of the slowing of energetic neutrons.

Thermal neutron logs were run only in water or mud-filled boreholes. Logs cannot be acquired in air-filled boreholes because of lack of adequate moderation of energetic neutrons. As a consequence, most thermal neutron logs were acquired in the saturated zone. Logs were acquired in the unsaturated zone only in boreholes filled with mud during logging: USW G-1, GU3 , and G-4. All thermal neutron logs considered here were acquired in open (uncased) hole.

Correction for borehole effects. The thermal neutron measurement is sensitive to borehole diameter. An enlarged hole produces an apparent porosity value greater than the true formation porosity. For example, a true porosity of 0.10 would give a reading of 0.10 in a hole of 7.9 inches diameter, but would give a reading of 0.125 in a hole enlarged to 10.9 inches (Dresser 
Atlas, 1985). Thus a correction of 0.025 is required. From inspection of correction charts (Birdwell, 1983), it can be seen that a correction for borehole size is substantially greater than any other correction for thermal neutron logs acquired at Yucca Mountain. Other effects, for which no correction was applied, are those of temperature, pressure, salinity, and mud weight, and mud cake thickness. As estimated from the Birdwell correction charts, the uncertainty in porosity produced by these combined effects is less than 0.01 .

Excavation effect. As previously mentioned, a few NBC logs were obtained at elevations above static water level in mud-filled boreholes. In partially saturated rock, a correction is required to the apparent neutron porosity (Segesman and Liu, 1971). The slowing down of neutrons at high energy is partially controlled by oxygen in the rock matrix. Partially saturated rock behaves as if that matrix were missing or excavated, hence the phenomenon is called the excavation effect. The excavation effect is accounted for implicitly in the algorithms described in the previous section for the ENP tool. However, the thermal neutron log requires an explicit correction,

$$
\Delta \phi=\left(\rho_{\mathrm{ma}} / 2.65\right)\left(1-\mathrm{S}_{\mathrm{w}}\right)\left(2 \phi^{2} \mathrm{~S}_{\mathrm{w}}+0.04\right)
$$

where $\Delta \phi$ is the correction added to the borehole-corrected neutron porosity, $\phi$, which we designate as $\phi_{\mathrm{w}}$ in this report. $\rho_{\mathrm{ma}}$ is the grain density and $\mathrm{S}_{\mathrm{w}}$ is the fractional water saturation. The correction is maximum at water saturation of 0.5 , and increases with porosity. For example, for $\rho_{\mathrm{ma}}=2.65, \phi=0.2$, and $S_{w}=0.7 ; \Delta \phi=0.03$; whereas for $\phi=0.4$, and $S_{w}=0.5 ; \Delta \phi=0.1$. The correction must be applied with great care in zeolitic zones where $S_{v}$ is uncertain. The correction was required in the unsaturated zone in boreholes USW G-1, GU-3/G-3, and G-4.

Implementation. NBC logs were recorded as porosity in percent (Nelson and others, 1991). The corrected NBC logs reported here are in fractional units for compatibility with porosity and water estimates from the epithermal neutron $\log$. Thus an original value of $20.0 \%$ could be reported here as 0.187 , after correction. Computations for the thermal neutron tools were coded into module NBCCORR (figure 2).

\section{Dielectric Logs}

Background. Dielectric logs were added to the logging program at Yucca Mountain in 1983 and obtained during 1983 and 1984 in boreholes UE-25p\#1, UE-25c\#1, c\#2, c\#3, USW UZ-1, USW UZ-6, and in all fifteen of the WT-series of boreholes. Refer to the plates in Nelson and others (1991) for dates and depths of logging. These logs were acquired with a tool operated by Atlas Wireline Services, which has a single transmitter and two coils measuring amplitude and phase difference of a continuous $47-\mathrm{MHz}$ electromagnetic wave. The amplitude ratio and phase difference data are transformed during logging to dielectric permittivity and resistivity logs. The supplier does not give any correction charts for borehole effects; no corrections were applied to the dielectric logs.

Conversion Algorithm. An algorithm that transforms the dielectric, resistivity, and gammagamma density logs to air-filled porosity, $\phi_{a}$, and water-filled porosity, $\phi_{w}$, was presented by Nelson (1993b): 


$$
\phi_{\mathrm{a}}=\left[\varrho_{\mathrm{g}}-\mathrm{Q}-\phi_{\mathrm{w}}\left(\varrho_{\mathrm{g}}-\varrho_{\mathrm{w}}\right)\right] / \mathrm{\varrho}_{\mathrm{g}}
$$

and,

$$
\phi_{w}=R e \frac{\sqrt{\epsilon}-\sqrt{\epsilon_{g}}+\left(\sqrt{\epsilon_{g}}-\sqrt{\epsilon_{a}}\right)\left(\varrho_{g}-\mathrm{Q}\right) / \varrho_{g}}{\sqrt{\epsilon_{w}}-\sqrt{\epsilon_{g}}+\left(\sqrt{\epsilon_{g}}-\sqrt{\epsilon_{a}}\right)\left(\varrho_{g}-\varrho_{w}\right) / \varrho_{g}}
$$

where

$\epsilon$ is the dielectric permittivity of the rock, measured with the log,

$\epsilon_{\mathrm{g}}$ is the dielectric permittivity of the rock matrix (grain),

$\epsilon_{\mathrm{w}}$ is the dielectric permittivity of water,

$\epsilon_{\mathrm{a}}$ is the dielectric permittivity of air,

$\varrho$ is measured density, from a density $\log$,

$\varrho_{\mathrm{g}}$ is grain or matrix density,

$\varrho_{w}$ is density of water, taken to be $1.0 \mathrm{~g} / \mathrm{cm}^{3}$.

The dielectric terms $\epsilon, \epsilon_{\mathrm{g}}$, and $\epsilon_{\mathrm{w}}$ are complex quantities, as required to describe an attenuating electromagnetic wave. The real and imaginary parts of the dielectric terms are,

$$
\operatorname{Re}(\epsilon)=\epsilon_{\mathrm{r}} ; \quad \operatorname{Im}(\epsilon)=1 /\left(\omega \epsilon_{\mathrm{o}} \mathrm{R}\right)
$$

where $R$ is resistivity in ohm-m. At these frequencies, it can assumed that dielectric losses $\left(\epsilon_{\xi}\right)$ can be ignored and that electrical conductivity $(1 / R)$ is real. Values of dielectric permittivity used to compute $\phi_{\mathrm{a}}$ and $\phi_{\mathrm{w}}$, in complex notation (real, imaginary) are: $\epsilon=\left(\right.$ diel, $1 /\left(\omega \epsilon_{\mathrm{o}}\right.$ rdiel $), \epsilon_{\mathrm{g}}=$ $\left(\epsilon_{\mathrm{gr}}, 0.0\right), \epsilon_{\mathrm{w}}=\left(88.0-0.375 \mathrm{~T}, 1 /\left(\omega \epsilon_{\mathrm{o}} \mathrm{R}_{\mathrm{w}}\right)\right)$, and $\epsilon_{\mathrm{a}}=(1.0,0.0)$. The value diel is the dielectric $\log$ value (figure 2 ) and $r$ diel is the resistivity $\log$ value measured with the dielectric tool. The term 88-0.375T accounts for the temperature dependence of $\epsilon_{\mathrm{wr}}$; temperatue $\mathrm{T}$ is represented by ltemp in figure $2 . \mathrm{R}_{\mathrm{w}}$ is the formation water resistivity, for which a uniform value of $16 \mathrm{ohm}-\mathrm{m}$ was used. The angular frequency $\omega=2 \pi \mathrm{f}$ where $f=47 \mathrm{MHz}$. The numerical evaluation of $Q$ and $\varrho_{\mathrm{g}}$ has been discussed in previous sections.

Matrix Permittivity. To ascertain the value of $\epsilon_{\mathrm{gr}}$, which is the real part of ${ }_{\mathrm{g}} \epsilon$, laboratory measurements were carried out on 10 unaltered and 5 zeolitic samples (table 5). Permittivity was first measured on samples as received in the laboratory in November, 1993, after 10 years of storage in core boxes at the Nevada Test Site (As is column in table 5). Next, water was added to the samples in three steps ("1stsat" through "3rdsat"). The measurement "3rdsat" was made after enough water was added to saturate the sample. Finally measurements were made after drying the samples at $105^{\circ} \mathrm{C}$ for one hour and then for up to 24 hours (last two columns in table 5).

Permittivity increases as water is added to the samples, then decreases after drying. Values of 4.5 to 5 were determined in the laboratory (Table 5) on samples dried at $105^{\circ} \mathrm{C}$ for one hour and then for up to 24 hours. This drying was probably excessive and removed monolayers of water in equilibrium with grain surfaces. Knight and Endres (1990) show that stripping away the first three or four monolayers of water leads to a value of permittivity for a completely dried grain 
that is inappropriate for use in the mixing law which leads to our equations 8 and 9 . The mean value of the ten unaltered "as is" measurements is 6.02 with a standard deviation of 1.01 . The samples probably lost pore water during storage, but without oven drying, retained the surficial monolayers. Whether drying during storage was excessive is not known. The as-is measurements are judged to provide a realistic, but minimum, value of $\epsilon_{\mathrm{gr}}$.

Table 5. Dielectric permittivity as function of saturation for 15 samples at 47 MHz, from Zhang and Shen (1994). Porosity (por.) values are estimates derived from measurements on neighboring samples. Five zeolitic(*) samples have as-is permittivity values greater than 10.0 .

\begin{tabular}{|c|c|c|c|c|c|c|c|c|c|}
\hline \multirow[b]{2}{*}{ Sample } & \multirow[b]{2}{*}{ Hole } & \multirow[b]{2}{*}{ Depth } & \multirow[b]{2}{*}{ Por. } & \multicolumn{3}{|c|}{ - - - - } & Permittivit & \multicolumn{2}{|c|}{-ー-ー-ー-ー- } \\
\hline & & & & As_is & 1stsat & 2ndsat & 3 rdSat & Dry1hr & Dry24hr \\
\hline 27518 & GU3 & 498.1 & 18.0 & 5.6460 & 6.5103 & 7.6300 & 8.3051 & 4.2210 & 4.4070 \\
\hline 27520 & GU3 & 699.5 & 11.0 & 5.1148 & 6.1930 & 6.5609 & 7.0818 & 4.5847 & 4.5944 \\
\hline 27521 & GU3 & 774.0 & 14.0 & 6.3837 & 6.7538 & 8.0280 & 8.1200 & 4.4091 & 4.2282 \\
\hline 27523 & GU3 & 937.3 & 17.0 & 6.2629 & 7.3649 & 7.8447 & 8.3385 & 4.4658 & 4.5425 \\
\hline 27525 & GU3 & 450.8 & 19.6 & 6.0280 & 7.0188 & 8.0858 & 9.1857 & 4.1891 & 4.2831 \\
\hline 27526 & GU3 & 1149.6 & 10.0 & 5.8795 & 6.4367 & 7.2059 & 7.3448 & 4.8980 & 4.3965 \\
\hline 27528 & $\mathrm{G} 4$ & 734.9 & 12.0 & 5.1473 & 8.2249 & 8.7116 & 9.0780 & 5.7509 & 4.5000 \\
\hline 27530 & $\mathrm{G} 4$ & 1190.0 & 10.0 & 8.5692 & 8.6396 & 9.2683 & 9.3445 & 4.3640 & 4.3344 \\
\hline $27531 *$ & G4 & 1390.0 & 15.0 & 12.5930 & 12.4834 & 14.9818 & 16.3012 & 4.8699 & 4.2652 \\
\hline 27532 * & G4 & 1538.8 & 36.0 & 12.4484 & 14.7497 & 18.6433 & 19.2851 & 5.5304 & 4.7100 \\
\hline 27533 * & G4 & 1691.7 & 35.0 & 14.5988 & 17.0275 & 20.0925 & 22.5392 & 6.0225 & 5.0427 \\
\hline 27535 & G4 & 305.2 & 14.8 & 5.1945 & 6.1400 & 6.2254 & 6.6815 & 4.1380 & 4.6728 \\
\hline 27536 & G4 & 1302.3 & 10.0 & 5.9747 & 6.1006 & 6.9194 & 6.9935 & 5.0899 & 4.6019 \\
\hline $27537 *$ & G4 & 1464.5 & 32.0 & 15.5814 & 20.7491 & 22.7566 & 23.0212 & 5.1647 & 4.3602 \\
\hline $27538 *$ & G4 & 1595.7 & 33.0 & 16.9123 & 19.2616 & 22.0743 & 22.9678 & 5.7334 & 4.8282 \\
\hline
\end{tabular}

Implementation. Equations 8 and 9 are coded using complex Fortran notation in module DIEL, so that $\phi_{\mathrm{w}}$ and $\phi_{\mathrm{a}}$ can be computed as a function of depth and presented in well log format. As a practical matter, the computations based upon the dielectric logs received much less attention than those based upon neutron logs, because dielectric logging was limited and was not available at all in the $\mathrm{G}$-series or $\mathrm{H}$-series of boreholes. A single example is included under the section "Examples" to show that under good conditions the information obtained with a dielectric log is comparable to that obtained with a epithermal neutron log.

\section{COMPUTATION OF POROSITY AND WATER CONTENT}

\section{Unsaturated Zone}

Total porosity is designated $\phi_{\mathrm{t}}$. The portion of the pore space filled with water, given as a fraction of total rock volume, is referred to as water-filled porosity, $\phi_{w}$, and that portion filled with air as air-filled porosity, $\phi_{\mathrm{a}}$, so that $\phi_{\mathrm{t}}=\phi_{\mathrm{w}}+\phi_{\mathrm{a}}$.

The relationship between bulk density measured by the density $\log \rho_{b}$ and $\phi_{w}$ is 


$$
\rho_{\mathrm{b}}=\rho_{\mathrm{g}}\left(1-\phi_{\mathrm{\nu}}\right)+\rho_{\mathrm{w}} \phi_{\mathrm{w}}+\rho_{\mathrm{a}} \phi_{\mathrm{a}}
$$

where $\rho_{\mathrm{g}}$ is the grain density, $\rho_{\mathrm{w}}$ is the water density, and $\rho_{\mathrm{a}}$ is the air density. The last term in equation 10 can be ignored because the air density is nearly zero, and the solution for total porosity is,

$$
\phi_{\mathrm{t}}=1-\rho_{\mathrm{b}} / \rho_{\mathrm{g}}+\left(\rho_{\mathrm{w}} / \rho_{\mathrm{g}}\right) \phi_{\mathrm{w}}
$$

In rocks free of clay and zeolite, most hydrogen is in pore water, and hydrogen index $I_{H}$ is equivalent to $\phi_{\mathrm{w}}$. However in the presence of zeolites or clays containing structural water, $\mathrm{I}_{\mathrm{H}}$ will be greater than $\phi_{w}$ by $\phi_{z}$, the volume fraction of structural water.

$$
\mathrm{I}_{\mathrm{H}}=\phi_{\mathrm{w}}+\phi_{\mathrm{z}}
$$

Now $I_{H}$ is adopted as an estimate of $\phi_{w}$, an estimate which will be valid only where $\phi_{z}$ is zero. Thus, once $I_{H}$ is determined from equation 3 or 4 (and 6), total porosity can be determined from,

$$
\phi_{\mathrm{t}}{ }^{\prime}=1-\rho_{\mathrm{b}} / \rho_{\mathrm{g}}+\left(\rho_{\mathrm{w}} / \rho_{\mathrm{g}}\right) \mathrm{I}_{\mathrm{H}}
$$

Saturation is defined as

$$
\mathrm{S}_{\mathrm{w}}=\phi_{\mathrm{w}} / \phi_{\mathrm{t}}
$$

and analogously with equation 13 , saturation is computed as

$$
\mathrm{S}_{\mathrm{w}}{ }^{\prime}=\mathrm{I}_{\mathrm{H}} / \phi_{\mathrm{t}}{ }^{\prime}
$$

Thus in the unsaturated zone we have adopted $\mathrm{I}_{\mathrm{H}}$ as an estimate of $\phi_{\mathrm{w}}, \phi_{\mathrm{t}}^{\prime}$ as an estimate of $\phi_{l}$, and $S_{w}{ }^{\prime}$ as an estimate of $S_{w}$. These estimates become equivalences only when the rock is free of hydrogeneous minerals. Otherwise, $\phi_{\mathrm{t}}^{\prime}$ (equation 13) will overestimate $\phi_{\mathrm{t}}$,

$$
\frac{\phi_{\mathrm{t}}{ }^{\prime}}{\phi_{\mathrm{t}}}=\frac{1-\rho_{\mathrm{b}} / \rho_{\mathrm{g}}+\left(\rho_{\mathrm{w}} / \rho_{\mathrm{g}}\right)\left(\phi_{\mathrm{w}}+\phi_{\mathrm{z}}\right)}{1-\rho_{\mathrm{b}} / \rho_{\mathrm{g}}+\left(\rho_{\mathrm{w}} / \rho_{\mathrm{g}}\right) \phi_{\mathrm{w}}}
$$

or,

$$
\phi_{\mathrm{t}}{ }^{\prime} / \phi_{\mathrm{t}}=1+\left(\rho_{\mathrm{w}} / \rho_{\mathrm{g}}\right)\left(\phi_{\mathrm{z}} / \phi_{\mathrm{v}}\right)
$$

Likewise, $S_{\mathrm{w}}{ }^{\prime}$ (equation 15) will differ from $S_{\mathrm{w}}$,

$$
\mathrm{S}_{\mathrm{w}}{ }^{\prime} / \mathrm{S}_{\mathrm{w}}=\left(\mathrm{I}_{\mathrm{H}} / \phi_{\mathrm{t}}{ }^{\prime}\right) /\left(\phi_{\mathrm{w}} / \phi_{\mathrm{t}}\right)
$$

or, 


$$
\mathrm{S}_{\mathrm{w}}{ }^{\prime} / \mathrm{S}_{\mathrm{w}}=\left[1+\left(\phi_{\mathrm{z}} / \phi_{\mathrm{w}}\right)\right] /\left[1+\left(\rho_{\mathrm{w}} / \rho_{\mathrm{g}}\right)\left(\phi_{\mathrm{z}} / \phi_{\mathrm{v}}\right)\right]
$$

A comparison of $\mathrm{I}_{\mathrm{H}}$ and $\phi_{\mathrm{t}}{ }^{\prime}$ leads to

$$
\frac{\mathrm{I}_{\mathrm{H}}}{\phi_{\mathrm{t}}^{\prime}}=\frac{\phi_{\mathrm{w}}+\phi_{\mathrm{z}}}{1-\rho_{\mathrm{b}} / \rho_{\mathrm{g}}+\left(\rho_{\mathrm{w}} / \rho_{\mathrm{g}}\right)\left(\phi_{\mathrm{w}}+\phi_{\mathrm{z}}\right)}
$$

This ratio exceeds 1.0 when

$$
\phi_{\mathrm{w}}+\phi_{\mathrm{z}}>\left(\rho_{\mathrm{g}}-\rho_{\mathrm{b}}\right) /\left(\rho_{\mathrm{g}}-\rho_{\mathrm{w}}\right)
$$

That is, $I_{H}$ exceeds $\phi_{t}{ }^{\prime}$ when the sum of $\phi_{w}+\phi_{z}$ is greater than $\left(\rho_{g}-\rho_{\mathrm{b}}\right) /\left(\rho_{\mathrm{g}}-\rho_{\mathrm{w}}\right)$. This latter term, equivalent to $\phi_{\mathrm{w}}$ in the saturated zone, approaches $\phi$ as $S$ approaches 1.0 in the unsaturated zone. A comparison of $\mathrm{I}_{\mathrm{H}}$ and $\phi_{\mathrm{t}}{ }^{\prime}$ in rock that is saturated or nearly saturated can serve to delineate zones that are massively zeolitized. In practice, this comparison is done by inspection in the uncored boreholes, taking geologic information into account. Zeolitized zones are then designated by a flag curve named zeolzone. Conversely, in lithophysal zones the rock is densely welded and not altered to zeolites, and the lithophysae contain air, not water. Consequently, $\phi_{\mathrm{t}}{ }^{\prime}$ exceeds $\mathrm{I}_{\mathrm{H}}$. Lithophysal zones are selected by inspection of $\phi_{\mathrm{t}}{ }^{\prime}, \mathrm{I}_{\mathrm{H}}$, and other logs, particularly the caliper which indicates hole enlargement. These intervals are designated by a flag curve named physzone.

\section{Saturated Zone}

In the saturated zone, $\phi_{\mathrm{a}}=0$ and $\phi=\phi$ in equation 10 , and the equation for total porosity becomes

$$
\phi_{\mathrm{t}}=\left(\rho_{\mathrm{g}}-\rho_{\mathrm{b}}\right) /\left(\rho_{\mathrm{g}}-\rho_{\mathrm{w}}\right)
$$

so that porosity is computed from the density log and the grain density estimate, without any contribution from a neutron log. Either the ENP or NBC log, after correction for borehole effects, can be used for $\mathrm{I}_{\mathrm{H}}=\phi_{\mathrm{w}}+\phi_{\mathrm{z}}$. In the saturated zone, an excess of $\mathrm{I}_{\mathrm{H}}$ over $\phi_{\mathrm{t}}$ can be used directly as an indicator of zeolites and smectite.

\section{Sensitivity to Errors}

In the unsaturated zone, the sensitivity of $\phi_{t}$ to errors in $\rho_{g}, \rho_{b}$, and $\phi_{w}$ can be found by differentiating equation 11 , yielding,

$$
\frac{\partial \phi_{\mathrm{t}}}{\partial \rho_{\mathrm{g}}}=\frac{\rho_{\mathrm{b}}-\rho_{\mathrm{w}} \phi_{\mathrm{w}}}{\rho_{\mathrm{g}}{ }^{2}}
$$

and 


$$
\frac{\partial \phi_{\mathrm{t}}}{\partial \rho_{\mathrm{b}}}=\frac{-1}{\rho_{\mathrm{g}}}
$$

and

$$
\frac{\partial \phi_{\mathrm{t}}}{\partial \phi_{\mathrm{w}}}=\frac{\rho_{\mathrm{w}}}{\rho_{\mathrm{g}}}
$$

In the saturated zone, the sensitivity of $\phi_{t}$ to errors in $\rho_{g}$ and $\beta$ can be found by differentiating equation 22 , yielding,

$$
\frac{\partial \phi_{t}}{\partial \rho_{g}}=\frac{1-\phi_{t}}{\rho_{g}-\rho_{w}}
$$

and

$$
\begin{array}{lc}
\partial \phi_{\mathrm{t}} & -1 \\
\hline \partial \rho_{\mathrm{b}} & \rho_{\mathrm{g}}-\rho_{w}
\end{array}
$$

Equations 23 and 24 will be used subsequently in a discussion of errors in estimating porosity.

\section{Grain Density}

Computation of porosity from density and water content from equations 11 or 22 requires an estimate of the grain density, $\rho_{\mathrm{g}}$. In cored holes, $\rho_{\mathrm{g}}$ estimates are best obtained from laboratory measurements, which are abundant in the G-series of boreholes and are sparse in holes that were spot cored (USW H-1, UE25p\#1) and sidewall cored (USW H-4). Grain density can also be estimated from x-ray diffraction data (Nelson, 1993a), which are available in most boreholes, except the WT-series (Bish and Chipera, 1989). X-ray diffraction data are nearly continuous in cored boreholes, such as the G-series, and are available at intermittent depths in other holes, from either cuttings or sidewall cores. Where neither core measurements nor X-ray diffraction data are available, $\rho_{\mathrm{g}}$ is assigned to discrete depth intervals by assigning a rock type to that interval. The association between rock type and characteristic density was made by Nelson and Anderson, (1992): glass, $2.349 \mathrm{~g} / \mathrm{cm}^{3}$; nonwelded tuff, 2.587; vitrophyre, 2.381; welded tuff, 2.540; deep zeolitization, 2.527; shallow zeolitization, 2.371. One of these six rock types is assigned to a depth interval by inspecting the borehole logs and geological description. In practice, $\rho_{\mathrm{g}}$ is established in most boreholes from a combination of rock type assignment, core measurements, and $\mathrm{X}$-ray diffraction data. Curve rhog contains the combined data for computational use (figure 2).

\section{Structural Water}

Epithermal and thermal neutron tools respond to all water in a rock, not just the water in 
pore space. Table 6 lists six ways in which water can be bound to or incorporated in the structure of minerals. Here the term "structural water" refers to all water contained within the molecular structure of a mineral, and hence to all categories in table 6, although the first three categories are assumed to be the most significant ones. The objective is to calculate the amount of structural water, and by subtraction then determine the amount of pore water.

\begin{tabular}{|c|c|}
\hline \multicolumn{2}{|c|}{$\begin{array}{l}\text { Table } 6 \text {. Terms used to describe how water is held in zeolitic or clay- } \\
\text { bearing rocks. Results of thermogravimetric analysis were used to } \\
\text { judge temperature ranges at which variously bonded water is lost. } \\
\text { From Knowlton and McKague (1976). }\end{array}$} \\
\hline $\begin{array}{l}\text { Adsorbed water: surface water held by ion-dipole } \\
\text { interaction, generally very loosely bound. }\end{array}$ & $\begin{array}{l}\text { Lost at } 25- \\
90^{\circ} \mathrm{C} \text {. }\end{array}$ \\
\hline $\begin{array}{l}\text { Zeolite water: water molecules occupying random } \\
\text { positions in cavities and channels within the crystal } \\
\text { framework of zeolites. }\end{array}$ & \multirow[t]{2}{*}{$\begin{array}{l}\text { Lost at } 70 \\
\text { to } 300^{\circ} \mathrm{C} \text {. }\end{array}$} \\
\hline $\begin{array}{l}\text { Interlayer water: water molecules occupying random } \\
\text { positions between crystal layers, present in layered } \\
\text { silicates such as montmorillonite. }\end{array}$ & \\
\hline $\begin{array}{l}\text { Coordinated water: water bound to cations in crystal } \\
\text { lattice by coordinate covalent bonding. }\end{array}$ & \multirow[t]{3}{*}{$\begin{array}{l}\text { Lost at } 200 \\
\text { to } 700^{\circ} \mathrm{C} \text {. }\end{array}$} \\
\hline $\begin{array}{l}\text { Anion water: water bound to lattice anions by } \\
\text { hydrogen bonding. }\end{array}$ & \\
\hline $\begin{array}{l}\text { Lattice water: water in the form of hydroxyl groups } \\
\text { ionically bonded in definite lattice positions. }\end{array}$ & \\
\hline
\end{tabular}

Tabulation of nuclear logging parameters by Ellis and others (1988) makes it possible to compute the response of thermal and epithermal neutron logging tools to minerals containing structural water. Their neutron response parameter $\phi_{\text {epi }}$ is tabulated in table 7 for the minerals analyzed by Bish and Chipera (1989).

The response parameter $\phi_{\text {epi }}$ is close to the volume fraction of water present in a given mineral. For example, an epithermal neutron tool in a fictitious formation of pure mordenite would give a reading of 0.252 . The response within a formation of known mineralogy is given by the sum over $\mathbf{N}$ minerals,

$$
\phi_{\mathrm{z}}=\Sigma \mathrm{f}_{\mathrm{i}} \phi_{\text {epi_i }}
$$

where $\mathrm{f}_{\mathrm{i}}$ is the volume fraction of a given mineral, derived from the data of Bish and Chipera (1989), $\phi_{\text {epi } i}$ is the neutron response from table 7 , and $\mathrm{i}=1, \ldots, N$. The response $\phi_{z}$ is converted from a limestone calibration scale, for which the coefficents in table 7 were derived, to a sandstone scale, which is more applicable to tuffs. Structural water can be computed only where mineral 
analyses are available.

\begin{tabular}{|c|c|c|c|}
\hline Mineral & Name & Formula & $\Phi_{\mathrm{eoi}}$ \\
\hline Feldspar & ffspar & $\mathrm{NaAlSi}_{3} \mathrm{O}_{8}, \mathrm{CaAl}_{2} \mathrm{Si}_{2} \mathrm{O}_{8}$ & -0.0125 \\
\hline Mica & fmica & $\mathrm{KAl}_{2}\left(\mathrm{AlSi}_{3} \mathrm{O}_{10}\right)(\mathrm{OH})_{2}$ & 0.134 \\
\hline Quartz & fqtz & $\mathrm{SiO}_{2}$ & -0.011 \\
\hline Tridymite & ftrid & $\mathrm{SiO}_{2}$ & -0.016 \\
\hline Cristobalite & fcrist & $\mathrm{SiO}_{2}$ & -0.016 \\
\hline Opal & fopal & $\mathrm{SiO}_{2}\left(\mathrm{H}_{2} \mathrm{O}\right)_{1209}$ & 0.033 \\
\hline Glass & fglass & -- & 0.000 \\
\hline Kaolinite & fkaol & $\mathrm{Al}_{4}\left(\mathrm{Si}_{4} \mathrm{O}_{10}\right)(\mathrm{OH})_{8}$ & 0.478 \\
\hline Smectite & fsmect & $\mathrm{Na}_{.33}\left(\mathrm{Al}_{1.67} \mathrm{Mg}_{.33}\right)\left(\mathrm{Si}_{4} \mathrm{O}_{10}\right)(\mathrm{OH})_{2} \bullet 4 \mathrm{H}_{2} \mathrm{O}$ & $\begin{array}{c}0.519 \\
{[0.222]}\end{array}$ \\
\hline Clinoptilolite & fclino & $\left(\mathrm{Ca}, \mathrm{Na}_{2}\right)\left(\mathrm{Al}_{2} \mathrm{Si}_{7} \mathrm{O}_{18}\right) \cdot 6 \mathrm{H}_{2} \mathrm{O}$ & 0.34 \\
\hline Mordenite & fmord & $\left(\mathrm{Na}_{2}, \mathrm{~K}_{2}, \mathrm{Ca}\right)\left(\mathrm{Al}_{2} \mathrm{Si}_{10} \mathrm{O}_{24}\right) \cdot 7 \mathrm{H}_{2} \mathrm{O}$ & 0.252 \\
\hline Analcime & fanal & $\mathrm{Na}\left(\mathrm{AlSi}_{2} \mathrm{O}_{6}\right) \cdot \mathrm{H}_{2} \mathrm{O}$ & 0.156 \\
\hline Calcite & fcalc & $\mathrm{CaCO}_{3}$ & 0.000 \\
\hline Hornblende & fhorn & $\mathrm{Ca}_{2} \mathrm{Fe}_{5}\left(\mathrm{Si}_{8} \mathrm{O}_{22}\right)(\mathrm{OH})_{2}$ & 0.089 \\
\hline Hematite & fhema & $\mathrm{Fe}_{2} \mathrm{O}_{3}$ & 0.055 \\
\hline Chlorite & fchlor & $\left(\mathrm{Mg}_{5}, \mathrm{Fe}_{5} \mathrm{Al}\right) \mathrm{Si}_{3} \mathrm{AlO}_{10}(\mathrm{OH})_{8}$ & 0.55 \\
\hline
\end{tabular}

How much variation in water content is to be expected for each of the minerals listed in table 7? Water content varies with chemical composition in one of the zeolites, analcime, and also varies with temperature and pressure in smectite. These variations are reviewed next.

The water content of analcime varies with chemical composition in two ways, according to Breck (1974). First, as the silica content increases, the number of $\mathrm{Na}^{+}$ions decreases, and water molecules occupy the sites. Thus there is a linear increase of water content with silica content. Second, as other larger ions such as $\mathrm{Li}$ or $\mathrm{K}$ substitute for $\mathrm{Na}$, they occupy water positions. Thus water content decreases with ion exchange. These substitutions, if present at Yucca Mountain, could produce substantial errors in water computed from the coefficient given in table 7. Analcime only occurs at depths greater than 3,000 feet (Bish and Chipera, 1989), but at these depths it is often the dominant zeolite.

Breck (1974) offers no similar analysis regarding chemically induced changes in water content in mordenite, heulandite, or clinoptilolite. However, heulandite changes structure if 
dehydrated at temperatures greater than $130^{\circ} \mathrm{C}$ and cannot then reabsorb water. Clinoptilolite, on the other hand, is very stable towards dehydration and can readily reabsorb water.

Structural water in clay minerals is reduced under conditions of increasing pressure and temperature. Dehydration of smectite has been studied (Bird, 1984) because it is considered fundamental to the understanding of fault displacement: montmorillonite and vermiculite are known to have a low coefficient of friction which varies with the number of layers of water. Calcium-montmorillonite hydrates more rapidly than sodium-montmorillonite and at a given depth and temperature $\mathrm{Ca}$-montmorillonite retains more water than $\mathrm{Na}$-montmorillonite. $\mathrm{Ca}$ montmorillonite is more prevalent at Yucca Mountain than Na-montmorillonite (D. Vaniman, D. Bish, personal communication). Bird's results indicate that $\mathrm{Ca}$-montmorillonite retains three layers of water at depths of 0 to 1 kilometer and two layers of water at depths of 1 to 4 kilometers. The value of $\phi_{\text {epi }}$ given for montmorillonite in table 7 can be presumed to be too high.

The neutron coefficient $\phi_{\text {epi }}$ for Ca-montmorillonite cannot be easily obtained from Bird's work, so an empirical approach was adopted using two X-ray diffraction samples from USW G-1, where montmorillonite volume fractions were around 0.5 . The corrected neutron log reading minus the porosity was taken as the structural water present; from this was subtracted the sum of the product of mineral fractions times their neutron coefficients, with smectite excluded. The remainder, attibuted to smectite, gave a neutron coefficient of 0.239 at 3810 feet and 0.205 at 3940 feet. An average of 0.222 was adopted for smectite, a value less than half the fully hydrated value of 0.519 given in table 7 .

Temperature and pressure effects in zeolites appear to be of much less concern than in montmorillonite. Thermodynamic evaluation of the water content of Na-clinoptilolite shows water content to be $0.328 \mathrm{gm} / \mathrm{cm}^{3}$ at $15^{\circ} \mathrm{C}$, declining to 0.307 at $75^{\circ} \mathrm{C}$ (Carey and Bish, 1995). These values agree fairly well with the value of 0.34 for clinoptilolite given in table 7 . An attempt was made to confirm the values of the water-bearing minerals using the $\mathrm{X}$-ray diffraction data and the neutron logs in boreholes, using multiple regression techniques. However, the results varied too much from one hole to another to be useful; this failure was attributed to errors (offsets) in the neutron log or the neutron corrections. It was decided that such errors overwhelm temperature or pressure effects on the order cited for clinoptilolite. Consequently the values cited in table 7 were deemed adequate and were used to compute structural water. The response to structural water is computed in module MINTRIM.

\section{Bulk Rock Composition}

Values of mineral volume fraction, $\mathrm{f}_{\mathrm{i}}$, are computed from the weight fractions compiled by Bish and Chipera (1989) using a method described by Nelson (1993a). The names of the variables of the volume fractions are listed in table 7 . For plotting purposes, groupings of these mineral volume fractions, designated $e_{i}$, have been selected:

$$
\begin{aligned}
& \text { efspar }=\text { ffspar }+ \text { fmica } \\
& \text { eqtz }=\text { efspar }+ \text { fqtz } \\
& \text { etrycr }=\text { eqtz }+ \text { ftrid }+ \text { fcrist }+ \text { fopal } \\
& \text { eglass }=\text { etrycr }+ \text { fglass } \\
& \text { esmect }=\text { eglass }+ \text { fkaol }+ \text { fsmect } \\
& \text { ezeol }=\text { esmect }+ \text { fclino }+ \text { fmord }+ \text { fanal }
\end{aligned}
$$




$$
\begin{aligned}
& \text { ecafe }=\text { ezeol }+ \text { fcalc }+ \text { fhorn }+ \text { fhema }+ \text { fchlor } \\
& 1.00=\text { ecafe }+ \text { porosity }
\end{aligned}
$$

The seven $\mathrm{e}_{\mathrm{i}}$ curves in equation 26 are computed cumulatively to allow shading to be used to display the mineral groups. The seven groups represent feldspar plus mica, quartz, low-density silica, glass, clay, zeolites, and calcite plus heavy minerals. By definition, when porosity is added to the total mineral volume fraction represented by ecafe, the fractions sum to 1.0 . Thus, the results of equation 26 permit plotting the mineralogy and porosity of bulk rock on a volume fraction basis.

Volume fractions $f_{i}$ occur only at discrete sample points, spaced tens of meters apart. Interpolation of the mineral groups $e_{i}$ is done linearly between sample points, weighted by porosity. Mineralogic volume fractions should not be interpolated across boundaries where changes in physical properties occur. Consequently, boundaries delineating changes in alteration mineralogy are picked by inspection of density, neutron, and electrical logs in combination with the mineralogy data. Alteration changes in the tuffs usually produce pronounced changes in physical properties at sharp boundaries. Selection of these boundaries is greatly aided by the degree of welding as described from core or cuttings. The mineral fractions e are then extrapolated down to (or up to) a boundary from the nearest sample point. These manipulations are similar to those done for structural water and are also carried out in module MINTRIM.

\section{EXAMPLES}

\section{Nomenclature}

Computations of porosity, water content, and saturation are plotted as curves in the examples that follow. Table 8 links the curve names to the mathematical nomenclature and definitions used in this report.

The following examples illustrate the computed porosity and water content responses in different lithologies and in both saturated and unsaturated rock. Refer to table 8 for definitions of curve names.

\section{Example \#1, uncored borehole USW H-1, saturated zone}

The lithologic sequence in the saturated zone of borehole USW H-1 consists of non-welded to partially welded Tram Tuff overlying non-welded Lithic Ridge Tuff, separated by a flow breccia with bedded tuff units above and below it (figure 15). The gap between water content from the epithermal neutron log (phiwenp) and porosity (phiden) is filled with a cross-hatch which represents the volumetric fraction of excess or structural water. Within the Lithic Ridge Tuff, structural water content is around 0.04 to 0.05 . A thermal neutron $\log$ was also run in this interval, and the resulting water content curve (phinbc) compares well with phiwenp over most of the interval. A few spot cores provide porosity measurements (stars at 3390 and 3410 feet) which confirm the computed porosity curve. This latter agreement, the agreement between the two water 


\begin{tabular}{||l|l|l||}
\hline \hline \multicolumn{2}{||l}{$\begin{array}{l}\text { Table } 8 . \text { Curve names for porosity, water content, and saturation computed from logs. All } \\
\text { curves are in units of fractional volumes. }\end{array}$} \\
\hline $\begin{array}{l}\text { Curve } \\
\text { Name }\end{array}$ & Definition & Explanation \\
\hline phiz & $\phi_{\text {, }}$, equation 25 & Structural water computed from mineralogy. \\
\hline phiwenp & $\mathrm{I}_{\mathrm{HU}}$, equation 6 & $\begin{array}{l}\text { Total water content from epithermal neutron log, } \\
\text { enp. }\end{array}$ \\
\hline phiwenpz & phiwenp - phiz & $\begin{array}{l}\text { Pore water content obtained by subtracting structural } \\
\text { water from total water content. }\end{array}$ \\
\hline phinbc & -- & $\begin{array}{l}\text { Total water content from thermal neutron log, nbc, } \\
\text { after correction for borehole effects. Usually } \\
\text { calculated in the saturated zone. }\end{array}$ \\
\hline phiwnbc & $\begin{array}{l}\text { phinbc with } \\
\text { correction } \Delta \phi, \\
\text { equation } 7\end{array}$ & $\begin{array}{l}\text { Total water content from thermal neutron log, } n b c, \\
\text { after correction for borehole effects and correction } \\
\text { for partial saturation. Usually calculated in the } \\
\text { unsaturated zone. }\end{array}$ \\
\hline phinbzc & $\begin{array}{l}\text { phinbc - phiz } \\
\text { or } \\
\text { phiwnbc - phiz }\end{array}$ & $\begin{array}{l}\text { Pore water content from thermal neutron log, } \\
\text { obtained by subtracting structural water from either } \\
\text { phiwnbc or phinbc. }\end{array}$ \\
\hline phitsplf & $\begin{array}{l}\phi_{\mathrm{t}}{ }^{\prime}, \text { equation } 13 \\
\text { Filtering of phitsplc }\end{array}$ & $\begin{array}{l}\text { Total porosity from combination of density and } \\
\text { epithermal neutron logs and grain density estimate. }\end{array}$ \\
\hline swenp & $\begin{array}{l}\mathrm{S}_{\mathrm{w}}{ }^{\prime}, \text { equation } 15 \\
\text { phitenp equation } 22\end{array}$ & $\begin{array}{l}\text { Total porosity from combination of density log and } \\
\text { grain density estimate. Usually calculated in the } \\
\text { saturated zone. }\end{array}$ \\
\hline phiden & $\begin{array}{l}\text { Total porosity spliced together from several } \\
\text { segments, each using a different computational } \\
\text { method. }\end{array}$ \\
\hline
\end{tabular}

content curves, and the consistency between structural water and observation of zeolitization in the geologic description (Rush and others, 1983), all lend assurance that the computed curves are reasonable.

\section{Example \#2, uncored borehole USW H-1, unsaturated zone}

The epithermal neutron, density, and gravimeter logs were used to compute porosity 
(phitenp) and water content (phiwenp) in figure 16. Because the water content is so much less than porosity, we infer that the rocks are essentially unaltered. This borehole is classified as uncored because it was not continuously cored. However, spot cores were taken. The comparison between the spot core measurements (open squares) and the computed logs is generally quite good.

The computed logs respond quite differently in the three regimes illustrated in figure 16 . The shallow ( 0 to 320 feet) sequence consists of bedded, non-welded, and non-welded to partially welded tuffs. No density log was obtained in this interval, so the gravimeter log was used to supply the bulk density values. Porosity values lie between 0.5 and 0.6 , and water content is around 0.24 . Because total water content is low relative to porosity, it is inferred that alteration of this sequence is minimal.

The computed logs indicate that the densely welded portion of Topopah Spring Tuff (Tpr) extends from 370 to 1420 feet. The interval from 1420 to 1460 is probably vitrophyre. A relatively constant water content of 0.10 to 0.13 is shown within the densely welded tuff, whereas porosity values range from 0.15 to 0.3 . As a consequence of the nearly constant water content, the variation in water saturation is primarily caused by variation in porosity. High porosity is attributed to lithophysal zones, as demarcated by the solid bars (physzone) and substantiated by the computation of lithophysal pore space (gpor) by Muller and Spengler (1989).

A non-welded zone extends from 1490 to 1800 feet within the Calico Hills Formation. Total water content is slightly less than porosity, producing an apparent water saturation of about 0.9. However, the Calico Hills Formation is typically highly altered to zeolite minerals, producing a total water content greater than the porosity. Without subsidiary data such as X-ray diffraction analyses, the total water content cannot be partitioned between pore water and structural water. Here, the Calico Hills Formation is highly porous and altered, although the alteration may not be as extensive as elsewhere.

\section{Example \#3, cored borehole USW G-1, saturated zone}

This example from borehole USW G-1 (figure 17) covers the same stratigraphic interval as nearby borehole USW H-1 (figure 15). Total water (phinbc) is derived from a thermal neutron $\log$. Structural water ( $p h i z$ ) is computed from mineralogy, and the resulting difference, equivalent to pore water (phinbcz), is shown in columns 2 and 3 of figure 17 . The excellent agreement between the total porosity (phiden) and pore water (phinbcz) confirms the validity of the computational processes for porosity, water content, and structural water. However, at 3300 feet phinbcz is substantially less than phiden. This anomalous interval is attributed to an overestimate of zeolite at the single X-ray diffraction sample at 3288 feet.

Although the porosity and water-content levels are quite similar within the partially welded tuffs of USW G-1 and USW H-1, the response is markedly different within the flow breccia and lavas. Water content is about 0.3 at 3700 to 3900 feet in USW G-1, even though porosity is much lower. The difference is contributed by structural water in smectite, as determined by X-ray diffraction. On the other hand, water content at 3900 feet in USW H-1 (figure 15) drops to 0.04, below the porosity value of 0.08 ; an unexplained discrepancy attributed to a mineralogical effect on the neutron log. The low water content in USW H-1 indicates that the flow breccia/lava is unaltered in USW H-1, whereas it is highly altered to smectite in USW G-1.

\section{Example \#4, cored borehole USW G-1, unsaturated zone}


Borehole USW G-1 provides a comparison of the epithermal neutron curve (phiwenp) and the thermal neutron curve (phinbc) in the unsaturated zone (column 2 of figure 18,350-680 feet). In this interval, there are almost no zeolitic or clay minerals, so structural water content, phiz, is nearly zero. Consequently, phinbcz and phinbc are indistinguishable, and both agree well with phiwenp. In column 3 of figure 18, the separation between porosity, phitenp, and water content, phiwenp, is shaded with a hatched pattern to indicate the air-filled porosity. From 430 to 580 feet, there is a large, unresolved disparity between the air-filled porosity pattern and an independent visual estimate of lithophysal pore space, dmvs. From 680 to 1230 feet, which includes the lower lithophysal zone, the thermal neutron $\log$ was of poor quality so that water content was not computed. Rather than leave this zone devoid of a porosity curve, a water content of 0.111 , equivalent to that determined in USW H-1, was used to compute a porosity curve.

The non-welded and bedded tuffs of the Calico Hills Formation, Tac, are extensively altered to the zeolite minerals clinoptilolite and mordenite; the resulting estimate of structural water, phiz, is subtracted from phinbc to produce the estimate of pore water, phinbcz. The average value of phinbcz, about 0.17 , compared to that of the porosity phiden, about 0.34 , shows that the Calico Hills Formation in USW G-1 is about 50\% saturated.

\section{Example \#5, cored borehole USW G-2, zeolitic zone}

Computation of water content in borehole USW G-2 is illustrated in figure 19. Water content has been computed from both the epithermal neutron (phiwenp) and the thermal neutron (phinbc) logs. These two estimates of water content are quite comparable in the Calico Hills Formation (Tac) but diverge below a depth of 3200 feet. The reason for the divergence is not known. Structural water, phiz, has been subtracted from the total water, phinbc, to yield a pore water estimate, phinbcz. Note that phinbcz is less than the porosity, phitsplf, indicating less than complete saturation throughout the Calico Hills Formation. Given the uncertainties in the computation of structural water, it is possible that phiz has been overestimated. The nominal static water level lies immediately above the top of Tac, but there is a possibility that this level is due to filling of the borehole by infiltration rather than a true static water level (Czarnecki and others, 1994). The true state of saturation and the wellbore hydraulics of USW G-2 are currently under study.

Porosity (phitsplf) has been used to compute the mineralogical volume fractions in column 1 of figure 19 , thus the wiggle character in the mineralogy fractions is due totally to the computed porosity log. Boundaries have been added at depths of 2704, 3009, 3044, 3298, and 3449 feet. The selection of these boundaries is based upon inspection of the original logs and the geological description; some of the inflections used for the picks can be seen in the porosity and water content curves. It is worth emphasizing that the mineralogy column incorporates three data sets: the Xray diffraction data taken at the sample depths shown by the ticks in column 1 , the computed porosity curve, and the boundaries that are inserted from inspection of geophysical logs.

\section{Example \#6, borehole USW WT-11, unsaturated zone}

Porosity, water content, and water saturation curves from the dielectric log and from the epithermal neutron log are compared in figure 20. The water content and saturation curves, originating from two very different physical measurements, track each other very well. The same 
density curve was used to calculate the porosity in both columns, so agreement is expected. The two air-filled porosity estimates indicated by the hatched areas, are comparable for the most part. Missing data in the dielectric column reflect the instability of the tool, which occasionally plagued the dielectric $\log$. The epithermal neutron log was more stable and was operated in more boreholes at Yucca Mountain than the dielectric tool. For these reasons the epithermal neutron tool has received more attention in this report.

\section{DISCUSSION OF ERRORS}

There are several ways to assess the errors in the estimates of porosity and water content. First, the computations can be compared with core measurements. Second, errors can be estimated for porosity by sensitivity analysis. Third, computed curves can be compared with other computed curves and examined for self-consistency.

\section{Comparison of log-based computations with core measurements.}

Summary statistics on differences between computed porosity and core-derived porosity are available for two intervals in the unsaturated zone and four intervals in the saturated zone (table 9). The mean value of the computed minus core porosity, given in the next-to-last column of table 9, represents the systematic error, while the standard deviation, given in the last column, represents the random error. Plots of computed vs. core-derived porosity for the same six intervals permit inspection of offsets and differences as a function of porosity (figure 21).

In the two unsaturated intervals, USW G-3 (UZ) and USW H-1 (UZ), the computed porosity is greater than the core porosity by 0.039 and 0.033 , with standard deviations that are comparable to the offsets. Note that the ranges in core porosity values in the two cases, 0.067 to 0.309 and 0.148 to 0.477 , are quite substantial. The intervals selected for this comparison excluded the lithophysal zones of the Topopah Spring Tuff, where the computed porosity is significantly greater than core porosity due to the under-representation of large lithophysal cavities from core samples. However, the G-3 (UZ) interval does include lithophysal-bearing zones of the Tiva Canyon Tuff, and hence the core-derived porosity values may be lower than actual in situ values. However, the USW H-1 (UZ) samples do not contain any lithophysal-bearing units, so another explanation must be sought. The borehole diameter of the upper 300 feet of USW H-1 is unusually large, and this subinterval includes the largest differences between computed and core porosity values. An erroneously low density reading related to the large diameter may be the cause of the disparity (see section Density Logs, Corrections).

The differences between computed and core porosity is less in the four saturated zone intervals than in the two unsaturated zone intervals. Mean differences are $-0.008,0.005,0.027$, and 0.021 . Errors are expected to be less in the saturated zone because the density logs required less correction and because there is one less variable involved in the computation of porosity (compare equation 11 with equation 22).

The differences cited in table 9 , taken from cored boreholes, are expected to be less than errors in uncored boreholes, which of course cannot be assessed in this fashion. 
Table 9. Comparison of log-based computed porosity and porosity measured on core samples, from the unsaturated zone (UZ) and saturated zone (SZ) in four boreholes. Last entry for $\mathrm{H}-1$ gives water content from core and computed water content minus core water content. Porosity and water content values are volume fractions. Depth range in feet.

\begin{tabular}{|c|c|c|c|c|c|c|c|c|c|}
\hline \multirow[b]{2}{*}{ Borehole } & \multirow[b]{2}{*}{ Depth } & \multirow[b]{2}{*}{ No. } & \multicolumn{3}{|c|}{-- core porosity -- } & \multicolumn{4}{|c|}{-- computed minus core -- } \\
\hline & & & $\min$ & $\max$ & mean & $\min$ & $\max$ & mean & stddev \\
\hline $\mathrm{G}-3$ (UZ) & $0-500$ & 25 & .067 & .309 & .137 & -.0335 & .1165 & .0393 & .0318 \\
\hline $\mathrm{H}-\mathrm{I}$ (UZ) & $0-500$ & 11 & .148 & .477 & .259 & -.0028 & .0830 & .0327 & .0245 \\
\hline $\mathrm{G}-1 \quad(\mathrm{SZ})$ & $2000-4000$ & 117 & .130 & .390 & .265 & -.0920 & .0879 & -.0079 & .0304 \\
\hline $\mathrm{G}-3 \quad(\mathrm{SZ})$ & $2600-5005$ & 44 & .018 & .311 & .194 & -.0317 & .0915 & .0053 & .0238 \\
\hline $\mathrm{G}-4 \quad(\mathrm{SZ})$ & $1800-3200$ & 23 & .113 & .350 & .244 & -.0189 & .0711 & .0271 & .0261 \\
\hline $\mathrm{H}-1 \quad(\mathrm{SZ})$ & $1900-6200$ & 25 & .073 & .335 & .226 & -.0308 & .131 & .0213 & .0415 \\
\hline & & & -- & e wat & --- & $--\operatorname{cor}$ & uted $r$ & minus $c$ & ore -- \\
\hline orehole & Depth & No. & $\min$ & $\max$ & mean & $\min$ & $\max$ & mean & stddev \\
\hline $1-1$ (UZ) & $0-1800$ & 41 & .0720 & .459 & .135 & -.0893 & .0572 & .0063 & .0287 \\
\hline
\end{tabular}

Water content measurements are available from borehole USW H-1, and a comparison of computed water and measurement from core samples is given in the bottom line of table 9 . Most of the core data come from the densely welded portion of Topopah Spring Tuff (figure 16) where little zeolite or clay exists. The result exceeds expectations, with a mean difference of 0.006 , showing essentially zero bias, and a standard deviation of 0.029 , showing little random error.

\section{Propagation of Error}

Propagation of error provides an estimate of systematic errors. In our case, a systematic error will persist over some finite portion of a borehole. A density log error, for example, could persist over the entire interval of a run of a particular density logging tool, which typically will be on the order of several hundred meters. On the other hand, grain densities are selected in a stepwise fashion because grain density is constant within distinct lithological intervals, which typically range from $20 \mathrm{~m}$ to $100 \mathrm{~m}$ in depth extent. Hence errors will appear to be constant (systematic) on the scale of a logging run or a lithologic interval, but will vary over the length of a borehole.

Assuming that errors in the three variables are independent, the overall uncertainty $\delta \phi_{\mathrm{t}}$ equals the square root of the summed squares of the three component uncertainties (Beers, 1957). A least-squares formulation allows for compensating errors, that is, for the liklihood that an error in one variable might increase the outcome while an error in another might decrease the outcome. The assumption of independence is reasonable, as the measurements of $\rho_{\mathrm{g}}, \rho_{\mathrm{b}}$, and $\phi_{\mathrm{w}}$ come from different sources, as explained at length in the preceding section. Then the overall uncertainty is 


$$
\delta \phi_{t}=\sqrt{\left(\frac{\partial \phi_{t}}{\partial \rho_{g}}\right)^{2}\left(\delta \rho_{g}\right)^{2}+\left(\frac{\partial \phi_{t}}{\partial \rho_{b}}\right)^{2}\left(\delta \rho_{b}\right)^{2}+\left(\frac{\partial \phi_{t}}{\partial \phi_{w}}\right)^{2}\left(\delta \phi_{w}\right)^{2}}
$$

Analysis using error propagation requires a model of the measurement or calculation procedure, which for the porosity computation is based upon equations 11 and 22 . Four cases have been selected for study (column 1 of table 10), based upon actual parameters from borehole USW H-1. Each case is assigned a value of grain density, bulk density, and water content, and from equation 11 or 22 , an expected value of $\phi_{t}$. Using equations 23 and 24 , the three partial derivatives required for equation 27 are then evaluated (not given in table 10). Next, expected errors $\delta \rho_{g}, \delta \rho_{w}$, and $\delta \phi_{w}$ (columns labeled "expected error" in table 10) are chosen from inspection of the data and from experience. For example, by comparing several logs over the same intervals in the saturated zone, Nelson and Schimschal (1993) found that a calibrated density $\log$ can be expected to determine the density to within $\pm 0.02 \mathrm{gm} / \mathrm{cm}^{3}$; hence $\delta \rho_{\mathrm{b}}$ is given as 0.02 for the third and fourth cases. Each partial derivative of equations 23 or 24 is then multiplied by the expected error of the appropriate variable, and the result is expressed as $\delta \phi_{\mathrm{eg}}, \delta \phi_{\mathrm{gb}}$, or $\delta \phi_{\phi \mathrm{w}}$ in table 10 , where $\delta \phi_{\mathrm{eg}}$ represents the first of three terms under the square root in equation 27. These three error terms are summed in accordance with equation 27 to give the overall uncertainty $\delta \phi_{\mathrm{t}}$ in the final column.

Table 10. Uncertainty in computed porosity based upon propagation of error for four cases: Uz/lith, lithophysal interval in unsaturated zone; Uz/zeol, zeolitic interval in unsaturated zone; sz/zeol, zeolitic interval in saturated zone; $\mathrm{sz} /$ deep, deep interval in saturated zone. Density values are in $\mathrm{gm} / \mathrm{cm}^{3}$, porosity values are in volume fractions. Uncertainties in porosity are given as magnitudes, without sign.
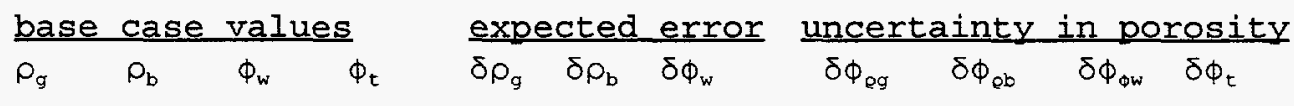

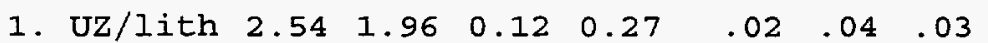

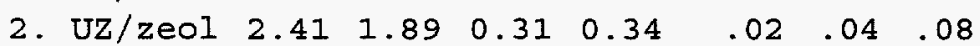

$.0057 \quad .020 \quad .015 \quad .026$

3. Sz/zeol $2.471 .99 \quad--0.33 \quad 02 \quad .02 \quad--$

4. Sz/deep $2.652 .51 \quad--0.09 \quad .02 \quad .02 \quad--$

$\begin{array}{llll}.0054 & .017 \quad .033 \quad .038\end{array}$

$.0091 .014 \quad-.016$

$.0110 .012 \quad--.016$

The overall uncertainties cited in table 10 range from 0.016 in the saturated zone to 0.038 in the unsaturated zone, and are quite comparable with the offsets found in the previous section by comparing computed porosity with core porosity. The expected errors used in table 10 represent good conditions, as do the comparisons with core data of table 9. That is, uncertainty will be higher in situations such as uncored boreholes where no core data are available and grain density must be estimated by lithological inference.

\section{Self-consistency}

Visual inspection of plots of porosity and water content gives a quick indication of the extent of agreement among porosity and water content computations. To quantify these 
comparisons, averages are presented in table 11 from intervals where both the thermal neutron and the epithermal neutron logs were available to compute water content. These intervals span a variety of tuff units, porosity values, and alteration types, as indicated, and were selected to obtain intervals of fairly constant separation between the thermal and epithermal neutron results. The procedures for obtaining water content were quite different for these two tools, even though both involve the slowing down of neutrons by hydrogen. Therefore the degree of consistency between the two provides a check on the computational procedures.

\begin{tabular}{|c|c|c|c|c|c|c|}
\hline \multicolumn{7}{|c|}{$\begin{array}{l}\text { Table 11. Averages of porosity and water content over depth } \\
\text { intervals of } 100 \text { or } 200 \text { feet in three boreholes. Porosity } \\
\text { (Por.) is average of either phiden or phitenp. Phiw is from } \\
\text { phiwenp. } \Delta \text { Phi is phinbc minus phiwenp. See table } 8 \text { for curve } \\
\text { name definitions. }\end{array}$} \\
\hline Borehole & Tuff & Alteration & Depth & Por. & Phiw & $\Delta \mathrm{Phi}$ \\
\hline \multirow[t]{2}{*}{ G-I (UZ) } & Tpt & $\begin{array}{l}\text { ualtered, } \\
\text { non-lith. }\end{array}$ & $350-450$ & .194 & .112 & .058 \\
\hline & Tpt & $\begin{array}{l}\text { unaltered, } \\
\text { lithophysal }\end{array}$ & $500-600$ & .306 & .234 & .011 \\
\hline \multirow[t]{6}{*}{$\mathrm{G}-2 \quad(\mathrm{SZ})$} & $\mathrm{Tac}$ & zeolitic & $1800-2000$ & .358 & .451 & .042 \\
\hline & Tac & zeolitic & $2000-2200$ & .311 & .402 & -.025 \\
\hline & Tac & zeolitic & $2200-2400$ & .323 & .372 & -.008 \\
\hline & Tac & zeolitic & $2400-2600$ & .350 & .372 & -.003 \\
\hline & Tcp & zeolitic & $3050-3250$ & .173 & .235 & .049 \\
\hline & $\mathrm{Tcb}$ & zeolitic & $3500-3700$ & .173 & .216 & .073 \\
\hline \multirow[t]{6}{*}{$\mathrm{H}-1 \quad(\mathrm{SZ})$} & $\mathrm{Tcb}$ & unaltered & $2350-2550$ & .251 & .257 & .002 \\
\hline & Tct & zeolitic & $3300-3500$ & .195 & .230 & .044 \\
\hline & $\mathrm{Tll}$ & unaltered? & $3850-3950$ & .076 & .041 & .058 \\
\hline & Tlr & zeolitic & $4400-4600$ & .178 & .218 & .013 \\
\hline & $\mathrm{Tt}$ & unaltered & $5000-5200$ & .166 & .182 & .010 \\
\hline & Tt & zeolitic & $5700-5900$ & .089 & .117 & .046 \\
\hline
\end{tabular}

In general, the water content from the thermal neutron log is equal to or greater than that from the epithermal $\log$, by as much as .073 volume fraction in one case. The difference exceeds 0.03 in half the cases. No lithologic or depth association with the neutron log separation has been noted. However, the thermal neutron $\log$ can be affected by the presence of a few minor elements with large thermal neutron absorption cross-sections (boron, iron, and others), which when present cause the log to read an erroneously high water content. The epithermal log, detecting neutrons with energies above absorption energies, is not susceptible to the presence of neutron absorbers. Thus the depth-varying presence of neutron-absorbing elements is a possible explanation for the 
varying separation between the two water content curves. If true, then the phinbc curve is likely to overestimate water content in some intervals. This is not critical, because the epithermal log was run in the air-filled holes of the unsaturated zone, where the water content estimate is quantitatively useful. In the saturated zone, where often only the thermal neutron log is available, the chief utility of phinbc is to select zeolitic zones. Other logs, such as resistivity, should be used in addition to phinbc for this purpose.

\section{SUMMARY}

The deep water table at the Yucca Mountain site requires that geophysical logs be run in air-filled holes, which are often rugose. In this environment, neutron and density logs have proven to be the most effective means of estimating porosity and water content from borehole logs. Other candidates are not as practical. Although the dielectric log is a promising option for water content determination, it was run late in the 1979-1984 logging program and, therefore, was not available in many holes.

Consequently, calculation of porosity and water content has required processing of neutron, density, caliper, and grain density logs. Caliper requires only some smoothing in zones of extreme hole rugosity. A grain density curve is prepared either from core, mineralogy, or lithological inference. The density curve corrections are based on core measurements of bulk density and are tailored to specific logging tool models. The epithermal neutron tool corrections for hole size and density are based upon calibrators built for the weapons testing program. Both the density and epithermal neutron curves required smoothing in zones of extreme hole rugosity. The thermal neutron tool corrections are taken from the suppliers' specifications.

The results appear to be sound quantitatively, particularly in cored holes where errors can be directly assessed. Uncertainties in the uncored (rotary) holes must be greater than in the cored holes, primarily because of greater uncertainty in estimating grain density. Uncertainties in the uppermost 500 feet of uncored holes will be greater than elsewhere because the epithermal neutron corrections are poorest in large diameter holes and at high water contents. Visual inspection of the results is effective in finding and correcting problems, by noting departures between water content and porosity that have no lithological or alteration dependence.

The porosity curve is combined with bulk mineralogy to produce a presentation of mineral groupings and porosity on a volumetric basis. The result has the appearance of a continuous whole rock analysis, with boundaries added where the logs indicate discontinuities in physical properties and hence in mineralogy. These mineralogical plots are particularly useful in examining results from borehole tests providing information on fluid flow such as temperature logs, fracture data, and pump tests. Thus the computed curves form a context for better understanding the hydrological regime.

\section{ACKNOWLEDGEMENTS}

Joyce Kibler of the USGS did much of the computational work and plotting of figures. Joe Hearst and Richard Carlson, both of Lawrence Livermore National Laboratory, and Jim Barber of IT Corporation supplied calibration values and a great deal of information regarding the ENP tools. Doug Muller of the USGS provided helpful comments during the course of this work. Pat Tucci and Mike Fahy of the USGS provided comprehensive reviews of the manuscript. 


\section{REFERENCES CITED}

Axelrod, M.C., and Hearst, J. R, 1984, Calibration of a neutron log in partially saturated media, Part IV: effects of sonde-wall gap: Transactions of 25th Annual Logging Symposium, Society of Prof. Well Log Analysts, paper Q, 18 p.

Beers, Y., 1957, Theory of error, Addison-Wesley Publ. Co., $66 \mathrm{p}$.

Bird, P., 1984, Hydration-phase diagrams and friction of montmorillonite under laboratory and geologic conditions, with implications for shale compaction, slope stability, and strength of fault gouge, Tectonophysics, v. 107, p. 235-260.

Birdwell, 1983, Log interpretation chart book, Tulsa, Okla., $117 \mathrm{p}$.

Bish, D., and Chipera, S., 1989, Revised mineralogic summary of Yucca Mountain, Nevada, Los Alamos National Laboratory report LA-11497-MS, 68 p.

Breck, D.W., 1974, Zeolite molecular sieves, John Wiley \& Sons, 771 p.

Carlson, R. C., 1993, Maximum likelihood borehole corrections for dual-detector density logs: Proceedings of the 5th International Symposium of Geophysics for Minerals, Geotechnical, and Environmental Applications, Minerals and Geotechnical Logging Society, paper AA, 6 p.

Carey, J.W., and Bish, D.L., 1996, Equilibrium in the Clinoptilolite- $\mathrm{H}_{2} \mathrm{O}$ system, American Mineralogist, v. 81, July-August.

Czarnecki, J.B., O'Brien, G.M., and Nelson, P.H., 1994, Is there perched water under Yucca Mountain in borehole USW G-2?: 1994 Fall Meeting of American Geophysical Union, Abstract H32A-2, p. 249.

Deupree, R.G., and Noel, S., 1988, Monte Carlo simulations of an epithermal neutron logging tool: The Log Analyst, 29, 2, p. 95-102.

Dresser Atlas, 1985, Log Interpretation Charts, Houston, Texas, 157 p.

Ellis, D., Howard, J., Flaum, C, McKeon, D., Scott, H., Serra, O., and Simmons, G., 1988, Mineral logging parameters: nuclear and acoustic, The Technical Review, v. 36, n. 1, p. 460-474.

Head, M.P., and Barnett, M.E., 1983, Digital log calculation of the compensated density log: J. of Petroleum Technology, p. 167-169.

Healey, D.L., Clutsom, F.G., and Glover, D.A., 1986, Borehole gravity meter survey in drill hole USW G-4, Yucca Mountain Area, Nye County, Nevada, U.S. Geological Survey Open-File Report 86-205, 18 p. 
Hearst, J. R, 1979, Calibration of a neutron $\log$ in partially saturated media: Transactions of 20th Annual Logging Symposium, Society of Prof. Well Log Analysts, paper B, 28 p.

Hearst, J. R, 1994, The Nevada Test Site neutron log calibrator, Lawrence Livermore National Laboratory, Report UCRL-ID-116379, 26 p.

Hearst, J. R, Kasameyer, P.W. and Dreilling, L.A., 1981, Calibration of a neutron log in partially saturated media, Part II: error analysis: Transactions of 22th Annual Logging Symposium, Society of Prof. Well Log Analysts, paper QQ, 47 p.

Hearst, J.R, and Nelson, P.H., 1985, Well logging for physical properties, McGraw-Hill Book Company, $571 \mathrm{p}$.

Knight, R., and Endres, A., 1990, A new concept in modeling the dielectric response of sandstones: defining a wetted rock and bulk water system, Geophysics, v. 55, n. 5, p. 586-594.

Nelson, P.H., Muller, D.C., Schimschal, U., and Kibler, J.E., 1991, Geophysical logs and core measurements from forty boreholes at Yucca Mountain, Nevada: U.S. Geological Survey Geophysical Investigations Map GP-1001, 64 p.

Nelson, P.H., and Anderson, L.A., 1992, Physical properties of ash-flow tuff from Yucca Mountain, Nevada, J. of Geophysical Research, v 97, no. B5, p 6823-6841, May 10.

Nelson, P.H., and Schimschal, U., 1993, Assessment of geophysical logs from borehole USW G-2, with recommendations for future logging at Yucca Mountain, Nevada, U.S. Geological Survey Open-File Report 92-572, 33 p.

Nelson, P.H., 1993a, Geological and mineralogical controls on physical properties at Yucca Mountain: The Log Analyst, v. 34, n. 1, p. 58-68.

Nelson, P.H., 1993b, Estimation of water-filled and air-filled porosity in the unsaturated zone, Yucca Mountain, Nevada, in Proc. of 4th Annual International Conf. on High Level Radioactive Waste Management, vol 1, Am. Nuclear Soc., p. 949-954.

Nelson, P.H., 1994, Saturation levels and trends in the unsaturated zone, Yucca Mountain, Nevada, Proceedings of the Fifth Annual International Conf. on High Level Radioactive Waste Management, Las Vegas, v. 4, p. 2774-2781.

Press, W.H., Flannery, B.P., Teukolshy, S.A., and Vetterling, W.T., 1986, Numerical recipes, the art of scientific computing, Cambridge University Press, $818 \mathrm{p}$.

Segesman, F. and Liu, O., 1971, The excavation effect, Transactions of 12th Annual Logging Symposium, Society of Prof. Well Log Analysts, paper N, 24 p.

Schimschal, U., 1993, Density adjustments in air-filled boreholes in volcanic rocks at Yucca 
Mountain, Nevada, The Log Analyst, v. 34, n. 4, p. 47-53.

Zhang, X. and Shen, L.C., 1994, Measured dielectric permittivity and conductivity of Yucca Mountain rock samples, Well Logging Laboratory, University of Houston, $14 \mathrm{p}$.

\section{APPENDIX A. LOGGING TOOL USAGE AT YUCCA MOUNTAIN, 1978-1984}

Tables A1, A2, and A4 give the logging tool model and serial numbers for each logging run made in boreholes at Yucca Mountain during the years 1978 to 1984 for the density, epithermal neutron, and thermal neutron logging tools. The information is taken from well log headers, adjusted to the run intervals posted on the Plates in Nelson and others, 1991. Table A3 lists the field calibration data for the epithermal neutron tools. 


\begin{tabular}{|c|c|c|c|c|c|}
\hline & \multicolumn{4}{|c|}{ 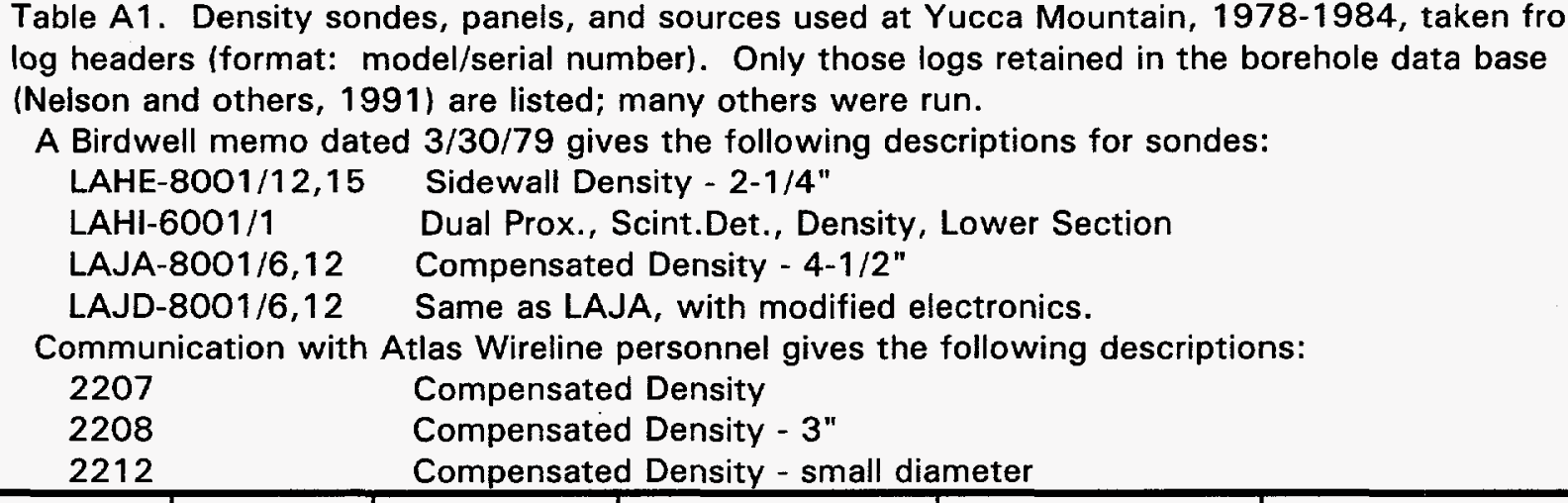 } \\
\hline Hole & Date & Depth & Panel & Sonde & Source \\
\hline A-1 & $08-26-78$ & $1250-2466$ & NA & LAHE-8001/15 & A-481 \\
\hline B-1H & $\begin{array}{l}04-22-81 \\
07-31-81 \\
\end{array}$ & $\begin{array}{c}292-1888 \\
1889-3993 \\
\end{array}$ & $\begin{array}{l}\text { LAJA-1001/10 } \\
\text { LAJD-1001/7 }\end{array}$ & $\begin{array}{l}\text { LAJA-8001/12 } \\
\text { LA/6 }\end{array}$ & $\begin{array}{l}\text { LAHA-3001/328 } \\
\text { LAHA-3001/328 }\end{array}$ \\
\hline C-1 & $\begin{array}{l}09-07-83 \\
10-02-83 \\
\end{array}$ & $\begin{array}{c}366-1509 \\
1510-2975 \\
\end{array}$ & $\begin{array}{l}\text { LAJD-1001/7 } \\
\text { LAJA-1001/10 }\end{array}$ & $\begin{array}{l}\text { LAJD-8001/6 } \\
\text { LAJD-8001/12 }\end{array}$ & $\begin{array}{l}\text { LAHA-3001/328 } \\
\text { LAHA-3001/328 }\end{array}$ \\
\hline C-2 & $\begin{array}{l}02-08-84 \\
02-28-84 \\
\end{array}$ & $\begin{array}{r}320-1510 \\
1512-2997 \\
\end{array}$ & $\begin{array}{l}\text { LAJA-1001/7 } \\
\text { LAJA-1001/7 }\end{array}$ & $\begin{array}{l}\text { LAJD-8001/6 } \\
\text { LAJD-8001/6 }\end{array}$ & $\begin{array}{l}\text { LAHA-3001/328 } \\
\text { LAHA-3001/328 }\end{array}$ \\
\hline$C-3$ & $\begin{array}{l}04-13-84 \\
04-27-84 \\
\end{array}$ & $\begin{array}{c}315-1513 \\
1514-3006 \\
\end{array}$ & $\begin{array}{l}\text { LAJA-1001/10 } \\
\text { LAJA-1001/7 }\end{array}$ & $\begin{array}{l}\text { LAJD-8001/12 } \\
\text { LAJD-8001/6 }\end{array}$ & $\begin{array}{l}\text { LAHA-3001/328 } \\
\text { LAHA-3001/332 }\end{array}$ \\
\hline G-1 & $\begin{array}{l}04-19-80 \\
09-14-80 \\
\end{array}$ & $\begin{array}{c}290-990 \\
1016-5878 \\
\end{array}$ & $\begin{array}{l}\text { LAJA-1001/6 } \\
3457 / 37039\end{array}$ & $\begin{array}{l}\text { LAJA-8001/6 } \\
2208 \mathrm{M} / 1\end{array}$ & $\begin{array}{l}\text { LAHA-3001/NA } \\
\text { S3E20/135 }\end{array}$ \\
\hline G-2 & $\begin{array}{l}05-19-81 \\
10-20-81 \\
10-20-81 \\
10-19-81 \\
\end{array}$ & $\begin{array}{c}288-2790 \\
2492-3201 \\
3202-4098 \\
4162-4692 \\
\end{array}$ & $\begin{array}{l}\text { LAJD-1001/7 } \\
3457 / 37059 \\
" \\
\text { " }\end{array}$ & $\begin{array}{l}\text { LAJD-1001/6 } \\
2208 / \mathrm{NA} \\
" \\
\end{array}$ & $\begin{array}{l}\text { LANA-3001/328 } \\
\text { S17S20/135 } \\
" \\
"\end{array}$ \\
\hline G-3 & $03-23-82$ & $2600-5028$ & $3751 / 48001$ & $2208 \mathrm{M} / 49501$ & S3E20/135 \\
\hline GU-3 & $\begin{array}{l}04-23-82 \\
04-30-82 \\
05-14-82 \\
\end{array}$ & $\begin{array}{c}35-1120 \\
1144-1750 \\
1771-2490 \\
\end{array}$ & $\begin{array}{l}\text { LAJD-1001/10 } \\
3751 / 48001 \\
3457 / 45800 \\
\end{array}$ & $\begin{array}{l}\text { LAJD-8001/6 } \\
2208 / 49509 \\
2208 / 49509 \\
\end{array}$ & $\begin{array}{l}\text { LAHA-3001/328 } \\
\text { S3E2O/135 } \\
\text { S3E2O/135 }\end{array}$ \\
\hline G-4 & $\begin{array}{l}09-19-82 \\
10-24-82 \\
11-21-82 \\
11-09-82 \\
\end{array}$ & $\begin{array}{c}46-452 \\
466-1775 \\
1776-1983 \\
1984-2991 \\
\end{array}$ & $\begin{array}{l}3751 / 47995 \\
\text { CLS/53926 } \\
\text { LAJD-1001/10 } \\
3751 / 47995 \\
\end{array}$ & $\begin{array}{l}2207 / 28132 \\
2212 / 37561 \\
\text { LAJD-8001/6 } \\
2208 M / 49509 \\
\end{array}$ & $\begin{array}{l}\text { S3T } 20 / 504 \\
\text { S3T } 20 / 450 \\
\text { LAHA-3001/328 } \\
\text { S3E2O/NA }\end{array}$ \\
\hline $\mathrm{H}-1$ & $\begin{array}{l}10-13-80 \\
11-25-80\end{array}$ & $\begin{array}{c}340-2256 \\
2257-6000\end{array}$ & $\begin{array}{l}\text { LAJD-1001/12 } \\
\text { LAJA-1001/10 }\end{array}$ & $\begin{array}{l}\text { LAJD-8001/12 } \\
\text { LAJA-8001/12 }\end{array}$ & $\begin{array}{l}\text { LAHA-3001/328 } \\
\text { LAHA-3001/328 }\end{array}$ \\
\hline $\mathrm{H}-3$ & $\begin{array}{l}02-19-82 \\
03-01-82 \\
\end{array}$ & $\begin{array}{r}127-2609 \\
2610-3988 \\
\end{array}$ & $\begin{array}{l}\text { LAJD-1001/10 } \\
\text { LAJD-1001/7 }\end{array}$ & $\begin{array}{l}\text { LAJD-8001/6 } \\
\text { LAJD-8001/12 }\end{array}$ & $\begin{array}{l}\text { LAHA-3001/328 } \\
\text { LAHA-3001/328 }\end{array}$ \\
\hline$H-4$ & $\begin{array}{l}04-01-82 \\
04-12-82 \\
04-29-82\end{array}$ & $\begin{array}{c}60-310 \\
311-1840 \\
1841-4003\end{array}$ & $\begin{array}{l}\text { NA } \\
\text { LAJD-1001/7 } \\
3751 / 48001\end{array}$ & $\begin{array}{l}\text { LAHI-8001/1 } \\
\text { LAJD-1001/12 } \\
2207 / 24722\end{array}$ & $\begin{array}{l}300 / 363 \\
\text { LAHA-3001/328 } \\
\text { S3T20/438 }\end{array}$ \\
\hline
\end{tabular}




\begin{tabular}{|c|c|c|c|c|c|}
\hline$H-5$ & $\begin{array}{l}06-11-82 \\
06-24-82 \\
\end{array}$ & $\begin{array}{r}312-2585 \\
2586-3995 \\
\end{array}$ & $\begin{array}{l}\text { LAJD-1001/5 } \\
3751 / 48001\end{array}$ & $\begin{array}{l}\text { LAJD-8001/6 } \\
2207 / 28132 \\
\end{array}$ & $\begin{array}{l}\text { LAHA-3001/328 } \\
\text { S3T20/435 }\end{array}$ \\
\hline $\mathrm{H}-6$ & $\begin{array}{l}09-04-82 \\
09-30-82 \\
\end{array}$ & $\begin{array}{r}312-1896 \\
1907-3980 \\
\end{array}$ & $\begin{array}{l}\text { LAJD-1001/7 } \\
\text { LAJD-1001/10 }\end{array}$ & $\begin{array}{l}\text { LAJD-8001/12 } \\
\text { LAJD-8001/6 }\end{array}$ & $\begin{array}{l}\text { LAHA-3001/328 } \\
\text { LAHA-3001/328 }\end{array}$ \\
\hline P-1 & $\begin{array}{l}11-16-82 \\
11-30-82 \\
01-18-83 \\
03-09-83 \\
05-03-83 \\
\end{array}$ & $\begin{array}{c}37-314 \\
325-1581 \\
1582-3922 \\
3991-4253 \\
4259-5910 \\
\end{array}$ & $\begin{array}{l}\text { LAJD-1001/10 } \\
\text { LAJD-1001/7 } \\
3752 / 58163 \\
\text { LAJD-1001/7 } \\
\text { LAJD-1001/7 }\end{array}$ & $\begin{array}{l}\text { LAJD-8001/6 } \\
\text { LAJD-8001/12 } \\
\text { NA/28132 } \\
\text { LAJD-8001/6 } \\
\text { LAJD-8001/6 } \\
\end{array}$ & $\begin{array}{l}\text { LAJA-8001/328 } \\
\text { LAHA-3001/328 } \\
\text { S3T20/438 } \\
\text { LAHA-3001/328 } \\
\text { LAHA-3001/328 }\end{array}$ \\
\hline$U Z-1$ & $07-19-83$ & $97-1261$ & LAJD-1001/7 & LAJD-8001/6 & LAHA-8001/328 \\
\hline UZ-6 & $09-28-84$ & $325-1856$ & $57833 \mathrm{H}$ & No305X & NA/767 \\
\hline WT-1 & $05-17-83$ & $33-1659$ & LAJD-1001/7 & LAJD-8001/6 & LAHA-3001/328 \\
\hline WT-2 & $07-14-83$ & $60-2047$ & LAJA-1001/7 & LAJD-8001/6 & LAHA-3001/328 \\
\hline WT-3 & $05-24-83$ & $40-1129$ & LAJD-1001/7 & LAJD-8001/6 & LAHA-3001/328 \\
\hline WT-4 & $06-05-83$ & $51-1566$ & LAJA-1001/7 & LAJD-8001/6 & LAHA-3001/328 \\
\hline WT-6 & $06-28-83$ & $251-1240$ & LAJD-1001/7 & LAJD-8001/6 & LAHA-3001/328 \\
\hline WT-7 & $07-25-83$ & 53-1589 & LAJA-1001/7 & LAJD-8001/6 & LAHA-3001/328 \\
\hline WT-10 & $07-31-83$ & $114-1384$ & LAJA-1001/7 & LAJD-8001/6 & LAHA-3001/328 \\
\hline WT-11 & $08-08-83$ & 44-1443 & LAJA-1001/7 & LAJD-8001/6 & LAHA-8001/328 \\
\hline WT-12 & $08-15-83$ & $70-1298$ & LAJA-1001/7 & LAJD-8001/6 & LAHA-3001/328 \\
\hline WT-13 & $07-06-83$ & $222-1130$ & LAJA-1001/7 & LAJD-8001/6 & LAHA-3001/328 \\
\hline WT-14 & $09-26-83$ & 223-1302 & LAJD-1001/7 & LAJD-8001/6 & LAHA-3001/328 \\
\hline WT-15 & $11-20-83$ & $133-1347$ & LAJA-1001/7 & LAJC-8001/6 & LAHA-3001/328 \\
\hline WT-16 & $11-08-83$ & 103-1688 & LAJA-1001/7 & LAJD-8001/6 & LAHA-3001/328 \\
\hline WT-17 & $10-27-83$ & 89-1389 & LAJA-1001/7 & LAJD-8001/6 & LAHA-3001/328 \\
\hline WT-18 & $05-22-84$ & $90-1964$ & LAJA-1001/7 & LAJD-8001/6 & LAHA-3001/328 \\
\hline
\end{tabular}




\begin{tabular}{|c|c|c|c|c|c|}
\hline \multicolumn{6}{|c|}{$\begin{array}{l}\text { Table A2. Epithermal neutron tools run at Yucca Mountain, 1979-1984. Information taken from well } \\
\text { log headers. Empty box indicates no entry. All tools were Birdwell tools. Bit diameter in inches, } \\
\text { bottom logging depth in feet. }\end{array}$} \\
\hline Well & $\begin{array}{c}\text { Bit Size/ } \\
\text { Depth }\end{array}$ & Date & $\begin{array}{l}\text { Sonde Model/ } \\
\text { Serial }\end{array}$ & $\begin{array}{l}\text { Source Model/ } \\
\text { Serial }\end{array}$ & $\begin{array}{l}\text { Calib Model/ } \\
\text { Serial }\end{array}$ \\
\hline G-1 & $\begin{array}{c}17.5^{\prime \prime} / \\
280^{\prime}\end{array}$ & $3 / 16 / 80$ & $\begin{array}{l}\text { LABE-6001/ } \\
\mathrm{Z}-193\end{array}$ & $\begin{array}{l}\text { LABA-3001/ } \\
\text { MRC-291 }\end{array}$ & $\begin{array}{l}\text { LMJA-6001/ } \\
\times 1\end{array}$ \\
\hline G-1 & $\begin{array}{c}6.25 " \prime \\
750^{\prime} \\
\end{array}$ & $4 / 22 / 80$ & $\begin{array}{l}\text { LABE-6001/ } \\
\mathrm{Z}-193\end{array}$ & $\begin{array}{l}\text { LABA-3001/ } \\
291\end{array}$ & $\begin{array}{l}\text { LMJA-6501/ } \\
\times 1\end{array}$ \\
\hline G-2 & $\begin{array}{l}6.25 " \prime \\
2784 !\end{array}$ & $5 / 20 / 81$ & $\begin{array}{l}\text { LABE-6001/ } \\
\text { Z-193 }\end{array}$ & $\begin{array}{l}\text { LABA-3001/ } \\
\text { MRC-291 }\end{array}$ & $\begin{array}{l}\text { LMJA-6001/ } \\
\times 1\end{array}$ \\
\hline G-2 & $\begin{array}{l}6.25 " / \\
3866^{\prime} \\
\end{array}$ & $9 / 01 / 81$ & $\begin{array}{l}\text { LABE-6001/ } \\
\mathrm{Z}-193\end{array}$ & $\begin{array}{l}\text { LABA-1001/ } \\
\text { MRC-291 }\end{array}$ & $\begin{array}{l}\text { LMJB-1001/ } \\
9\end{array}$ \\
\hline G-3 & $\begin{array}{l}8.75 " / \\
2200^{\prime} \\
\end{array}$ & $2 / 08 / 82$ & $\begin{array}{l}\text { LABE-6001/ } \\
\mathrm{Z}-145\end{array}$ & $\begin{array}{c}\prime \\
\text { MRC-291 }\end{array}$ & $\begin{array}{l}\text { LMJA-6501/ } \\
\times 1\end{array}$ \\
\hline B-1H & $\begin{array}{l}12.25 \\
8.75 " \\
1888^{\prime} \\
\end{array}$ & $4 / 23 / 81$ & $\begin{array}{l}\text { LABE-6001/ } \\
\text { Z-193 }\end{array}$ & $\begin{array}{l}\text { LABA-1001/ } \\
291\end{array}$ & $\begin{array}{l}\text { LMJB-1001/ } \\
9\end{array}$ \\
\hline B-1H & $\begin{array}{r}8.5 " \prime \\
3985^{\prime}\end{array}$ & $8 / 08 / 81$ & $\begin{array}{l}\text { LABE-6001/ } \\
\text { Z-193 }\end{array}$ & $\begin{array}{l}\text { LABA-3001/ } \\
\text { MRC-291 }\end{array}$ & $\begin{array}{l}\text { LMJA-6501/ } \\
\times 1\end{array}$ \\
\hline P-1 & $\begin{array}{c}14.75^{\prime \prime} / \\
1584^{\prime} \\
\end{array}$ & $\begin{array}{l}12 / 01 / 82 \\
\text { with shield }\end{array}$ & $\begin{array}{l}\text { LABE-6001/ } \\
23\end{array}$ & $\begin{array}{l}\text { LABA-3001/ } \\
289\end{array}$ & $\begin{array}{l}\text { LMJA-6501/ } \\
23\end{array}$ \\
\hline P-1 & $\begin{array}{c}9.875 " / \\
3924 \\
\end{array}$ & $\begin{array}{l}1 / 17 / 83 \\
\text { with shield }\end{array}$ & $\begin{array}{l}\text { LABE-6001/ } \\
23\end{array}$ & $\begin{array}{l}\text { LABA-3001/ } \\
\text { MRC-289 }\end{array}$ & $\begin{array}{l}\text { LMJA-6501/ } \\
23\end{array}$ \\
\hline P-1 & $\begin{array}{l}6.75 " / \\
5918^{\prime}\end{array}$ & $\begin{array}{l}5 / 03 / 83 \\
\text { no shield }\end{array}$ & $\begin{array}{l}\text { LABE-6001/ } \\
23 \text { MOD } 4\end{array}$ & $\begin{array}{l}\text { LABA-3001/ } \\
\text { MRC-289 }\end{array}$ & $\begin{array}{l}\text { LMJB-1001/ } \\
23\end{array}$ \\
\hline $\mathrm{H}-1$ & $\begin{array}{c}20.0^{\prime \prime} / \\
335^{\prime} \\
\end{array}$ & $9 / 13 / 80$ & $\begin{array}{l}\text { LABE-6001/ } \\
\text { Z-193 }\end{array}$ & $\begin{array}{l}\text { LABA-3001/ } \\
\text { MRC-291 }\end{array}$ & $\begin{array}{l}\text { LMJA-6501/ } \\
\times-1\end{array}$ \\
\hline $\mathrm{H}-1$ & $\begin{array}{c}13.25 ", \\
12.25 " / \\
2257^{\prime \prime}\end{array}$ & $10 / 13 / 80$ & $\begin{array}{l}\text { LABE-6001/ } \\
145\end{array}$ & $\begin{array}{l}\text { LABA-3001/ } \\
\text { MRC-291 }\end{array}$ & $\begin{array}{l}\text { LMJA-1001/ } \\
X-1\end{array}$ \\
\hline $\mathrm{H}-1$ & $\begin{array}{l}8.75 " / \\
6000^{\prime} \\
\end{array}$ & $11 / 28 / 80$ & $\begin{array}{l}\text { LABE-6001/ } \\
\text { Z-145 }\end{array}$ & $\begin{array}{l}\text { LABA-3001/ } \\
\text { MRC-291 }\end{array}$ & \\
\hline $\mathrm{H}-3$ & $\begin{array}{c}14.75^{\prime \prime} / \\
2615^{\prime}\end{array}$ & $2 / 19 / 82$ & $\begin{array}{l}\text { LABE-6001/ } \\
16, \text { MOD } 4\end{array}$ & $\begin{array}{l}\text { LABA-3001/ } \\
\text { MRC-291 }\end{array}$ & $\begin{array}{l}\text { LMJB-1001/ } \\
16\end{array}$ \\
\hline $\mathrm{H}-3$ & $\begin{array}{l}8.75 " \prime \\
3992 ' \\
\end{array}$ & $3 / 02 / 82$ & $\begin{array}{l}\text { LABE-6001/ } \\
16, \text { MOD } 4\end{array}$ & $\begin{array}{l}\text { LABA-3001/ } \\
289\end{array}$ & $\begin{array}{l}\text { LMJA-6501/ } \\
16\end{array}$ \\
\hline $\mathrm{H}-4$ & $\begin{array}{c}14.75^{\prime \prime} / \\
1842^{\prime} \\
\end{array}$ & $4 / 12 / 82$ & $\begin{array}{l}\text { LABE-6001/ } \\
21, \text { MOD4 }\end{array}$ & $\begin{array}{l}\text { LABA-3001/ } \\
289\end{array}$ & $\begin{array}{l}\text { LMJA-6501/ } \\
21\end{array}$ \\
\hline
\end{tabular}




\begin{tabular}{|c|c|c|c|c|c|}
\hline$H-5$ & $\begin{array}{c}14.75 " / \\
2584 \\
\end{array}$ & $6 / 10 / 82$ & $\begin{array}{l}\text { LABE-6001/ } \\
23, \text { MOD } 4\end{array}$ & $\begin{array}{l}\text { LABE-3001 } \\
289 \\
\end{array}$ & $\begin{array}{l}\text { LMJA-6501/ } \\
23\end{array}$ \\
\hline$H-6$ & $\begin{array}{c}14.74^{\prime \prime} / \\
1905^{\prime}\end{array}$ & $9 / 07 / 82$ & $\begin{array}{l}\text { LABE-6001/ } \\
23\end{array}$ & $\begin{array}{l}\text { LABA-3001/ } \\
289\end{array}$ & $\begin{array}{l}\text { LMJA-6501/ } \\
23\end{array}$ \\
\hline$C-1$ & $\begin{array}{c}24.0^{\prime \prime} / \\
365^{\prime}\end{array}$ & $\begin{array}{l}8 / 22 / 83 \\
\text { green sh }\end{array}$ & $\begin{array}{l}\text { LABE-6001/ } \\
23\end{array}$ & $\begin{array}{l}\text { LABE-3001 } \\
\text { MRC-289 }\end{array}$ & $\begin{array}{l}\text { LMJA-6501/ } \\
23\end{array}$ \\
\hline$C-1$ & $\begin{array}{c}14.75 " / \\
1512^{\prime}\end{array}$ & $\begin{array}{l}9 / 08 / 83 \\
\text { green sh }\end{array}$ & $\begin{array}{l}\text { LABE-6001/ } \\
21\end{array}$ & $\begin{array}{l}\text { LABE-3001 } \\
\text { MRC-289 }\end{array}$ & $\begin{array}{l}\text { LMJA-6501/ } \\
21\end{array}$ \\
\hline $\mathrm{C}-1$ & $\begin{array}{c}9.875^{\prime \prime} / \\
2991^{\prime} \\
\end{array}$ & $\begin{array}{l}9 / 20 / 83 \\
\text { green sh }\end{array}$ & $\begin{array}{l}\text { LABE-6001/ } \\
23\end{array}$ & $\begin{array}{l}\text { LABA-3001 } \\
\text { MRC-289 }\end{array}$ & $\begin{array}{l}\text { LMJA-6501/ } \\
23\end{array}$ \\
\hline$C-2$ & $\begin{array}{c}24.0^{\prime \prime} / \\
317^{\prime} \\
\end{array}$ & $\begin{array}{l}1 / 29 / 84 \\
\text { green sh }\end{array}$ & $\begin{array}{l}\text { LABE-6001/ } \\
23\end{array}$ & $\begin{array}{l}\text { LABA-3001 } \\
\text { MRC-291 }\end{array}$ & LMJA-6501 \\
\hline$C-2$ & $\begin{array}{c}14.75^{\prime \prime} / \\
1514^{\prime} \\
\end{array}$ & $\begin{array}{l}2 / 8 / 84 \\
\text { green sh }\end{array}$ & $\begin{array}{l}\text { LABE-6001/ } \\
23 \bmod 4\end{array}$ & $\begin{array}{l}\text { LABA-3001 } \\
\text { MRC-289 }\end{array}$ & $\begin{array}{l}\text { LMJA-6501/ } \\
23\end{array}$ \\
\hline$C-3$ & $\begin{array}{c}14.75^{\prime \prime} / \\
1515^{\prime}\end{array}$ & $\begin{array}{l}4 / 13 / 84 \\
\text { green sh }\end{array}$ & $\begin{array}{l}\text { LABE-6001/ } \\
23 \bmod 4\end{array}$ & $\begin{array}{l}\text { LABA-3001 } \\
\text { MRC-291 }\end{array}$ & $\begin{array}{l}\text { LMJA-2501/ } \\
23\end{array}$ \\
\hline WT-1 & $\begin{array}{l}8.75 " / \\
1665 \prime \\
\end{array}$ & $5 / 17 / 83$ & $\begin{array}{l}\text { LABE-6001/ } \\
23\end{array}$ & $\begin{array}{l}\text { LABA-3001 } \\
\text { MRC-289 }\end{array}$ & $\begin{array}{l}\text { LMJA-6501/ } \\
23\end{array}$ \\
\hline WT-2 & $\begin{array}{l}8.75 " / \\
2045 ! \\
\end{array}$ & $\begin{array}{l}7 / 14 / 83 \\
\text { no shield } \\
\end{array}$ & $\begin{array}{l}\text { LABE-6001/ } \\
23 \text { mod } 4\end{array}$ & $\begin{array}{l}\text { LABA-3001 } \\
\text { MRC-289 }\end{array}$ & $\begin{array}{l}\text { LMJA-6501/ } \\
23\end{array}$ \\
\hline WT-3 & $\begin{array}{l}8.75 \% / \\
1131 \% \\
\end{array}$ & $\begin{array}{l}5 / 24 / 83 \\
\text { no shield } \\
\end{array}$ & $\begin{array}{l}\text { LABE-6001/ } \\
23 \bmod 4\end{array}$ & $\begin{array}{l}\text { LABA-3001 } \\
\text { MRC-289 }\end{array}$ & $\begin{array}{l}\text { LMJA-6501/ } \\
23\end{array}$ \\
\hline WT-4 & $\begin{array}{l}8.75^{\prime \prime} / \\
1568^{\prime} \\
\end{array}$ & $\begin{array}{l}6 / 05 / 83 \\
\text { no shield } \\
\end{array}$ & $\begin{array}{l}\text { LABE-6001/ } \\
23\end{array}$ & $\begin{array}{l}\text { LABA-3001 } \\
\text { MRC-289 }\end{array}$ & $\begin{array}{l}\text { LMJA-6501/ } \\
23\end{array}$ \\
\hline WT-6 & $\begin{array}{l}6.75 " / \\
1242 ' \\
\end{array}$ & $6 / 28 / 83$ & $\begin{array}{l}\text { LABE-6001/ } \\
21 \bmod 4\end{array}$ & $\begin{array}{l}\text { LABA-3001 } \\
\text { MRC-289 }\end{array}$ & $\begin{array}{l}\text { LMJA-6501/ } \\
21\end{array}$ \\
\hline WT-7 & $\begin{array}{l}8.75 " \prime \\
1586 ! \\
\end{array}$ & $7 / 25 / 83$ & $\begin{array}{l}\text { LABE-6001/ } \\
21\end{array}$ & $\begin{array}{l}\text { LABA-3001 } \\
\text { MRC-289 }\end{array}$ & $\begin{array}{l}\text { LMJA-6501/ } \\
21\end{array}$ \\
\hline WT-10 & $\begin{array}{l}8.75 " \prime \\
1387 ' \\
\end{array}$ & $\begin{array}{l}7 / 31 / 83 \\
\text { w 2" skid } \\
\end{array}$ & $\begin{array}{l}\text { LABE-6001/ } \\
21 \bmod 4\end{array}$ & $\begin{array}{l}\text { LABA-3001 } \\
\text { MRC-289 }\end{array}$ & $\begin{array}{l}\text { LMJA-6501/ } \\
21\end{array}$ \\
\hline WT-11 & $\begin{array}{l}8.75 " / \\
1445^{\prime} \\
\end{array}$ & $\begin{array}{l}8 / 08 / 83 \\
w 3 " \text { skid } \\
\end{array}$ & $\begin{array}{l}\text { LABE-6001/ } \\
21\end{array}$ & $\begin{array}{l}\text { LABA-3001 } \\
\text { MRC-289 }\end{array}$ & $\begin{array}{l}\text { LMJA-6501/ } \\
21\end{array}$ \\
\hline WT-12 & $\begin{array}{l}8.75 " / \\
1297 \\
\end{array}$ & $8 / 15 / 83$ & $\begin{array}{l}\text { LABE-6001/ } \\
21 \bmod 4\end{array}$ & $\begin{array}{l}\text { LABA-3001 } \\
\text { MRC-289 }\end{array}$ & $\begin{array}{l}\text { LMJA-6501/ } \\
21\end{array}$ \\
\hline WT-13 & $\begin{array}{l}8.75^{\prime \prime} / \\
1130^{\prime} \\
\end{array}$ & $7 / 06 / 83$ & $\begin{array}{l}\text { LABE- } 6001 / \\
23 \bmod 4\end{array}$ & $\begin{array}{l}\text { LABA-3001 } \\
\text { MRC-289 }\end{array}$ & $\begin{array}{l}\text { LMJA-6501/ } \\
23\end{array}$ \\
\hline WT-14 & $\begin{array}{l}8.75^{\prime \prime} / \\
1305^{\prime} \\
\end{array}$ & $\begin{array}{l}9 / 27 / 83 \\
\text { w skid } \\
\end{array}$ & $\begin{array}{l}\text { LABE-6001/ } \\
23\end{array}$ & $\begin{array}{l}\text { LABA-3001 } \\
\text { MRC-289 }\end{array}$ & $\begin{array}{l}\text { LMJA-6501/ } \\
23\end{array}$ \\
\hline WT-15 & $\begin{array}{l}8.75 " / \\
1351 ' \\
\end{array}$ & $\begin{array}{l}11 / 20 / 83 \\
\text { w skid }\end{array}$ & $\begin{array}{l}\text { LABE-6001/ } \\
23\end{array}$ & $\begin{array}{l}\text { LABA-3001 } \\
\text { MRC-289 }\end{array}$ & $\begin{array}{l}\text { LMJA-6501/ } \\
23\end{array}$ \\
\hline
\end{tabular}




\begin{tabular}{|c|c|c|c|c|c|}
\hline WT-16 & $\begin{array}{l}8.75 " / \\
1710^{\prime} \\
\end{array}$ & $\begin{array}{l}11 / 08 / 83 \\
\text { w skid }\end{array}$ & $\begin{array}{l}\text { LABE-6001/ } \\
21\end{array}$ & $\begin{array}{l}\text { LABA-3001 } \\
\text { MRC-289 }\end{array}$ & $\begin{array}{l}\text { LMJA-6501/ } \\
21\end{array}$ \\
\hline WT-17 & $\begin{array}{l}8.75 " / \\
1390^{\prime}\end{array}$ & $\begin{array}{l}10 / 28 / 83 \\
\text { w skid }\end{array}$ & $\begin{array}{l}\text { LABE-6001/ } \\
20\end{array}$ & $\begin{array}{l}\text { LABA-3001 } \\
\text { MRC-289 }\end{array}$ & $\begin{array}{l}\text { LMJA-1001/ } \\
20\end{array}$ \\
\hline WT-18 & $\begin{array}{l}8.75 " ! \\
1965 !\end{array}$ & $5 / 21 / 84$ & $\begin{array}{l}\text { LABE-6001/ } \\
23\end{array}$ & $\begin{array}{l}\text { LABA-3001 } \\
\text { MRC-291 }\end{array}$ & $\begin{array}{l}\text { LMJA-6501/ } \\
23\end{array}$ \\
\hline UZ-1 & $\begin{array}{l}17.5 " / \\
1263 !\end{array}$ & $\begin{array}{l}7 / 19 / 83 \\
\text { green sh }\end{array}$ & $\begin{array}{l}\text { LABE-6001/ } \\
23\end{array}$ & $\begin{array}{l}\text { LABA-3001 } \\
\text { MRC-289 }\end{array}$ & $\begin{array}{l}\text { LMJA-6501/ } \\
23\end{array}$ \\
\hline UZ-6 & $\begin{array}{l}17.5 " / \\
1854\end{array}$ & $\begin{array}{l}9 / 28 / 84 \\
\text { shield \#4 }\end{array}$ & $\begin{array}{l}\text { LABE-6001/ } \\
21\end{array}$ & $\begin{array}{l}\text { LABA-3001 } \\
\text { MRC-289 }\end{array}$ & $\begin{array}{l}\text { LMJA-6501/ } \\
21\end{array}$ \\
\hline A-4 & $\begin{array}{c}8.75^{\prime \prime} / \\
494^{\prime}\end{array}$ & $7 / 19 / 79$ & $\begin{array}{l}\text { LABE-6001/ } \\
Z-145\end{array}$ & $\begin{array}{l}\text { LABA-3001 } \\
291\end{array}$ & $\begin{array}{l}\text { LMJA-1001/ } \\
9\end{array}$ \\
\hline A-5 & $\begin{array}{c}12.25^{\prime \prime} / \\
119^{\prime} \\
\end{array}$ & $6 / 28 / 79$ & $\begin{array}{l}\text { LABE-6001/ } \\
145\end{array}$ & $\begin{array}{l}\text { LABA-3001 } \\
291\end{array}$ & $\begin{array}{l}\text { LMJA-1001/ } \\
9\end{array}$ \\
\hline$A-5$ & $\begin{array}{c}6.125^{\prime \prime} / \\
488^{\prime} \\
\end{array}$ & $7 / 11 / 79$ & $\begin{array}{l}\text { LABE-6/ } \\
16\end{array}$ & MRC-287 & $\begin{array}{l}\text { LMJA-6501/ } \\
\times 1 \\
\end{array}$ \\
\hline A- 6 & $\begin{array}{c}6.125^{\prime \prime} / \\
95\end{array}$ & $7 / 22 / 79$ & $\begin{array}{l}\text { LABE-6001/ } \\
\mathrm{Z}-193\end{array}$ & $\begin{array}{l}\text { LABA-1001 } \\
291\end{array}$ & $\begin{array}{l}\text { LMJA-1001/ } \\
9\end{array}$ \\
\hline A-6 & $\begin{array}{r}6.125 ", \\
5.5 " / 500 \\
\end{array}$ & $7 / 31 / 79$ & $\begin{array}{l}\text { LABE-6/ } \\
Z-193\end{array}$ & $\begin{array}{l}\text { LABA-3001 } \\
\text { MRC } 287\end{array}$ & $\begin{array}{l}\text { LMJA-6501/ } \\
\times 1\end{array}$ \\
\hline$A-7$ & $\begin{array}{c}12.25 " / \\
131^{\prime} \\
\end{array}$ & $8 / 17 / 79$ & $\begin{array}{l}\text { LABE- } 6001 / \\
\mathrm{Z}-193 \bmod 2\end{array}$ & $\begin{array}{l}\text { LABA-3001 } \\
\text { MRC } 291\end{array}$ & $\begin{array}{l}\text { LMJA-6501/ } \\
\times 1\end{array}$ \\
\hline$A-7$ & $\begin{array}{l}5.5 \% / \\
500 \%\end{array}$ & $8 / 30 / 79$ & $\begin{array}{l}\text { LABE-6001/ } \\
Z-145\end{array}$ & $\begin{array}{l}\text { LABA-3001 } \\
\text { MRC } 291\end{array}$ & $\begin{array}{l}\text { LMJA-6501/ } \\
\times 1\end{array}$ \\
\hline
\end{tabular}


Table A3. Field calibration data from tails of ENP logs. BBU, both baffles up; 1BU, one baffle up; BBD, both baffles down. Last column gives ratio of API to count rate (cps) for both baffles up.

\begin{tabular}{|c|c|c|c|c|c|c|c|c|c|}
\hline $\begin{array}{l}\text { Hole } \\
\text { Name }\end{array}$ & Date & $\begin{array}{c}\text { Tool } \\
\text { No. }\end{array}$ & $\begin{array}{l}\mathrm{BBU} \\
\mathrm{API}\end{array}$ & $\begin{array}{l}\text { BBU } \\
\text { CDS }\end{array}$ & $\begin{array}{l}1 \mathrm{BU} \\
\mathrm{API}\end{array}$ & $\begin{array}{l}1 \mathrm{BU} \\
\mathrm{cPS}\end{array}$ & $\begin{array}{l}\text { BBD } \\
\text { API }\end{array}$ & $\begin{array}{l}\text { BBD } \\
\text { Cps }\end{array}$ & $\begin{array}{c}\text { BBU } \\
\mathrm{API} / \mathrm{cps}\end{array}$ \\
\hline $\mathrm{H} 3$ & 82.219 & 16 & 3251 & 290.37 & 1239 & 111.66 & 572 & 53.71 & 11.20 \\
\hline $\mathrm{H} 3$ & 82.255 & 16 & 3251 & 282.69 & 1239 & 111.89 & 572 & 50.97 & 11.50 \\
\hline WT17 & 83.910 & 20 & 3694 & 293.98 & 1430 & 110.91 & 653 & 50.47 & 12.57 \\
\hline H4 & 82.366 & 21 & 3016 & 273.70 & 1181 & 107.37 & 541 & 47.23 & 11.02 \\
\hline WT6 & 83.577 & 21 & 3016 & 281.63 & 1181 & 107.63 & 541 & 47.62 & 10.71 \\
\hline WT7 & 83.652 & 21 & 3016 & 284.13 & 1181 & 110.31 & 541 & 51.09 & 10.61 \\
\hline WT10 & 83.668 & 21 & 3016 & 290.13 & 1181 & 113.51 & 541 & 50.02 & 10.40 \\
\hline WT11 & 83.689 & 21 & 3016 & 285.69 & 1181 & 110.82 & 541 & 50.05 & 10.56 \\
\hline WT12 & 83.708 & 21 & 3016 & 283.73 & 1181 & 111.70 & 541 & 49.73 & 10.63 \\
\hline C1 & 83.772 & 21 & 3016 & 286.31 & 1181 & 110.95 & 541 & 49.10 & 10.53 \\
\hline WT16 & 83.939 & 21 & 3736 & 257.61 & 1448 & 98.63 & 701 & 43.80 & 14.50 \\
\hline UZ6 & 84.827 & 21 & 3736 & 260.22 & 1448 & 100.56 & 701 & 45.30 & 14.36 \\
\hline H5 & 82.527 & 23 & 3199 & 299.39 & 1237 & 114.35 & 567 & 51.95 & 10.69 \\
\hline H6 & 82.769 & 23 & 3199 & 282.89 & 1237 & 106.97 & 567 & 47.50 & 11.31 \\
\hline P1 & 83.003 & 23 & 3199 & 280.49 & 1237 & 104.52 & 567 & 47.83 & 11.41 \\
\hline $\mathrm{P} 1$ & 83.130 & 23 & 3199 & 282.47 & 1237 & 106.46 & 567 & 47.92 & 11.33 \\
\hline P1 & 83.425 & 23 & 3199 & 279.71 & 1237 & 103.74 & 541 & 47.47 & 11.44 \\
\hline WT1 & 83.463 & 23 & 3199 & 281.19 & 1237 & 106.84 & 567 & 48.42 & 11.38 \\
\hline WT3 & 83.482 & 23 & 3199 & 278.17 & 1237 & 106.43 & 567 & 47.25 & 11.50 \\
\hline WT4 & 83.514 & 23 & 3199 & 274.65 & 1237 & 104.32 & 567 & 46.86 & 11.65 \\
\hline WT13 & 83.600 & 23 & 3199 & 282.13 & 1237 & 105.76 & 567 & 47.93 & 11.34 \\
\hline WT2 & 83.622 & 23 & 3016 & 287.05 & 1181 & 110.35 & 541 & 51.31 & 10.51 \\
\hline UZ1 & 83.635 & 23 & 3199 & 279.95 & 1237 & 106.76 & 567 & 48.35 & 11.43 \\
\hline $\mathrm{Cl}$ & 83.727 & 23 & 3199 & 279.59 & 1237 & 105.72 & 567 & 48.70 & 11.44 \\
\hline $\mathrm{Cl}$ & 83.805 & 23 & 3199 & 278.74 & 1237 & 107.06 & 567 & 48.77 & 11.48 \\
\hline WT14 & 83.824 & 23 & 3199 & 276.91 & 1237 & 105.91 & 567 & 48.58 & 11.55 \\
\hline WT15 & 83.971 & 23 & 3199 & 279.18 & 1237 & 104.88 & 567 & 47.15 & 11.46 \\
\hline $\mathrm{C} 2$ & 84.163 & 23 & 3199 & 298.55 & 1237 & 114.43 & 567 & 52.53 & 10.72 \\
\hline $\mathrm{C} 2$ & 84.189 & 23 & 3199 & 281.26 & 1237 & 106.98 & 567 & 48.33 & 11.37 \\
\hline $\mathrm{C} 3$ & 84.369 & 23 & 3199 & 299.32 & 1237 & 113.86 & 567 & 52.20 & 10.69 \\
\hline WT18 & 84.474 & 23 & 3199 & 301.61 & 1237 & 115.66 & 567 & 52.54 & 10.61 \\
\hline A4 & 79.577 & 145 & 3789 & 313.40 & 1431 & 116.30 & 723 & 57.30 & 12.09 \\
\hline A5 & 79.613 & 145 & 3789 & 311.20 & 1431 & 115.20 & 723 & 56.32 & 12.18 \\
\hline A4 & 79.635 & 145 & 3789 & 307.00 & 1431 & 113.30 & 723 & 55.00 & 12.34 \\
\hline A7 & 79.749 & 145 & 3789 & 315.20 & 1431 & 116.10 & 723 & 58.20 & 12.02 \\
\hline $\mathrm{HI}$ & 80.869 & 145 & 3789 & 312.11 & 1427 & 115.43 & 723 & 58.31 & 12.14 \\
\hline $\mathrm{H} 1$ & 80.993 & 145 & -- & 305.10 & -- & 112.75 & - & 57.70 & - \\
\hline G3 & 82.189 & 145 & 3789 & 307.80 & 1431 & 115.73 & 723 & 57.33 & 12.31 \\
\hline A6 & 79.644 & 193 & 3789 & 295.00 & 1428 & 112.00 & 723 & 54.00 & 12.84 \\
\hline A6 & 79.668 & 193 & 3789 & 296.10 & 1431 & 107.40 & 723 & 54.10 & 12.80 \\
\hline A7 & 79.713 & 193 & 3789 & 289.30 & 1431 & 110.10 & 723 & 55.90 & 13.10 \\
\hline GI & 80.294 & 193 & 3789 & 298.40 & 1431 & 110.18 & 723 & 55.26 & 12.70 \\
\hline G1 & 80.394 & 193 & 3789 & 295.18 & 1431 & 111.01 & 723 & 53.36 & 12.84 \\
\hline $\mathrm{HI}$ & 80.786 & 193 & 3789 & 287.40 & 1431 & 107.10 & 723 & 52.80 & 13.18 \\
\hline $\mathrm{B} 1 \mathrm{H}$ & 81.396 & 193 & 3789 & 285.40 & 1428 & 104.30 & 725 & 54.60 & 13.28 \\
\hline G2 & 81.471 & 193 & 3789 & 292.69 & 1431 & 112.21 & 723 & 61.82 & 12.95 \\
\hline $\mathrm{B} 1 \mathrm{H}$ & 81.689 & 193 & 3789 & 290.90 & 1431 & 105.94 & 723 & 56.08 & 13.03 \\
\hline $\mathrm{G} 2$ & 81.753 & 193 & 3789 & 277.39 & 1431 & 101.75 & 723 & 53.28 & 13.66 \\
\hline
\end{tabular}




\begin{tabular}{|c|c|c|c|c|c|c|}
\hline Well & $\begin{array}{l}\text { Bit Size/ } \\
\text { Depth }\end{array}$ & $\begin{array}{l}\text { Hole } \\
\text { size on } \\
\text { panel/ } \\
\text { scale } \\
\end{array}$ & Date & $\begin{array}{l}\text { Sonde Model/ } \\
\text { Serial Number }\end{array}$ & $\begin{array}{l}\text { Source Model/ } \\
\text { Serial Number }\end{array}$ & $\begin{array}{l}\text { Calib Model/ } \\
\text { Serial Number }\end{array}$ \\
\hline B-1H & $\begin{array}{l}8.75 / \\
1881 \\
\end{array}$ & & $4 / 22 / 81$ & $\begin{array}{l}2413 / \\
42587 \\
\end{array}$ & $\begin{array}{l}\text { S17S20/ } \\
48501 \\
\end{array}$ & \\
\hline B-1H & $\begin{array}{l}8.5 / \\
4004 \\
\end{array}$ & & $7 / 30 / 81$ & $\begin{array}{l}2413 / \\
29899 \\
\end{array}$ & S17S20 & \\
\hline$C-1$ & $\begin{array}{l}9.875 / \\
2997 \\
\end{array}$ & & $9 / 18 / 83$ & $\begin{array}{c}\prime \\
63749 \\
\end{array}$ & $S 17520$ & \\
\hline$C-2$ & $\begin{array}{l}9.875 / \\
2997 \\
\end{array}$ & $\begin{array}{l}9.875 \\
\text { SS }\end{array}$ & $2 / 29 / 84$ & $\begin{array}{l}\text { LAGC-8001/ } \\
6 A\end{array}$ & $\begin{array}{l}\text { LABB-3001/ } \\
\text { MRC-404 }\end{array}$ & $\begin{array}{l}\text { LMQB-2001/ } \\
9\end{array}$ \\
\hline$C-3$ & $\begin{array}{l}9.875 / \\
3008\end{array}$ & $\begin{array}{l}9.875 \\
\text { SS }\end{array}$ & $4 / 27 / 84$ & $\begin{array}{l}\text { LAGC-8001/ } \\
6 A\end{array}$ & $\begin{array}{l}\text { LABB-3001/ } \\
\text { MRC-404 }\end{array}$ & $\begin{array}{l}\text { LMOB-2001/ } \\
9\end{array}$ \\
\hline G-1 & $\begin{array}{l}6.25 \prime \\
682 \\
\end{array}$ & --- & $4 / 22 / 80$ & $\begin{array}{l}\text { LAGA-8000/ } \\
8\end{array}$ & $\begin{array}{l}\text { LABB-3001/ } \\
\text { MRC-404 }\end{array}$ & \\
\hline G-1 & $\begin{array}{l}6.25 / \\
996 \\
\end{array}$ & $\begin{array}{l}6.25 \\
\text { LS }\end{array}$ & $4 / 19 / 80$ & $\begin{array}{l}\text { LAGA-8001/ } \\
8\end{array}$ & $\begin{array}{c}1 \\
\text { MRC-404 }\end{array}$ & $\begin{array}{l}\text { LMHA-1001/ } \\
5\end{array}$ \\
\hline G-1 & $\begin{array}{l}3.875 / \\
5878\end{array}$ & & $9 / 14 / 80$ & $\begin{array}{l}2418 / \\
31926 \\
\end{array}$ & $\begin{array}{l}\text { S17S20/ } \\
34371\end{array}$ & \\
\hline G-2 & $\begin{array}{l}6.25 / \\
2792 \\
\end{array}$ & & $5 / 22 / 81$ & $\begin{array}{l}2413 / \\
42587 \\
\end{array}$ & $\begin{array}{l}\text { S17S20/ } \\
32389\end{array}$ & \\
\hline G-2 & $\begin{array}{l}6.25 / 3108 \\
6.125 / 4120 \\
\end{array}$ & & $8 / 26 / 81$ & $\begin{array}{l}2413 / \\
42587\end{array}$ & $\begin{array}{l}S 17 \$ 20 / \\
48501\end{array}$ & \\
\hline G-3 & $\begin{array}{l}3.98 / \\
5029 \\
\end{array}$ & & $3 / 23 / 82$ & $\begin{array}{l}2418 / \\
39176 \\
\end{array}$ & $\begin{array}{l}\text { S17S20/ } \\
48501 \\
\end{array}$ & \\
\hline GU-3 & $\begin{array}{l}6.75 / \\
409 \\
\end{array}$ & $\begin{array}{l}6.25 \\
\text { SS }\end{array}$ & $4 / 3 / 82$ & $\begin{array}{l}\text { LAGC-8001/ } \\
6 A\end{array}$ & $\begin{array}{l}\text { LABB-3001/ } \\
\text { MRC-404 }\end{array}$ & $\begin{array}{l}\text { LMOB-2001/ } \\
9\end{array}$ \\
\hline GU-3 & $\begin{array}{l}6.75 / \\
1117 \\
\end{array}$ & $\begin{array}{l}6.25 \\
\text { SS } \\
\end{array}$ & $4 / 23 / 82$ & $\begin{array}{l}\text { LAGC-8001/ } \\
6 \mathrm{~A}\end{array}$ & $\begin{array}{l}\text { LABB-3001/ } \\
\text { MRC- } 404\end{array}$ & $\begin{array}{l}\text { LMOB-2001/ } \\
9\end{array}$ \\
\hline GU-3 & $\begin{array}{l}3.98 / \\
1742 \\
\end{array}$ & & $4 / 30 / 82$ & $\begin{array}{l}2418 / \\
39176 \\
\end{array}$ & $\begin{array}{l}\$ 17520 / \\
33589\end{array}$ & \\
\hline GU-3 & $\begin{array}{l}2.98 / \\
2607 \\
\end{array}$ & & $5 / 14 / 82$ & $\begin{array}{l}2418 / \\
39176 \\
\end{array}$ & $\begin{array}{l}S 17520 / \\
33589 \\
\end{array}$ & \\
\hline G-4 & $\begin{array}{l}6.75 / \\
453\end{array}$ & & $9 / 19 / 82$ & $\begin{array}{l}2413 / \\
29899\end{array}$ & $\begin{array}{l}\text { S17S20/ } \\
30323\end{array}$ & \\
\hline
\end{tabular}


Table A4. Compensated neutron tools run at Yucca Mountain, 1980-1984. Information taken from well log headers. Empty box indicates no entry. Bit diameter in inches, bottom logging depth in feet.

\begin{tabular}{|c|c|c|c|c|c|c|}
\hline G-4 & $\begin{array}{l}6.625 / \\
1670\end{array}$ & & $10 / 24 / 82$ & $\begin{array}{l}2413 / \\
32962 \\
\end{array}$ & $\begin{array}{l}\text { S17S20/ } \\
64865 \\
\end{array}$ & \\
\hline G-4 & $\begin{array}{l}12.25 / \\
1981\end{array}$ & $\begin{array}{l}12.25 \\
\text { SS }\end{array}$ & $11 / 21 / 82$ & $\begin{array}{l}\text { LAGC-8001/ } \\
6 A\end{array}$ & $\begin{array}{l}\text { LABB-3001/ } \\
\text { MRC-404 }\end{array}$ & $\begin{array}{l}\text { LMOB-2001/ } \\
9\end{array}$ \\
\hline G-4 & $\begin{array}{l}4.5 / \\
2991 \\
\end{array}$ & & $11 / 9 / 82$ & $\begin{array}{l}2418 / \\
39176 \\
\end{array}$ & S3T2O/ & \\
\hline $\mathrm{H}-1$ & $\begin{array}{l}8.75 / \\
6000 \\
\end{array}$ & & $12 / 31 / 80$ & $\begin{array}{l}2413 / \\
3459 \\
\end{array}$ & $\begin{array}{l}\text { S17S20/ } \\
3437\end{array}$ & \\
\hline $\mathrm{H}-3$ & $\begin{array}{l}8.75 / \\
3982\end{array}$ & & $3 / 2 / 82$ & $\begin{array}{l}2413 / \\
29900\end{array}$ & $\begin{array}{l}\mathrm{S} 17 \mathrm{~S} 2 \mathrm{O} / \\
48501\end{array}$ & \\
\hline $\mathrm{H}-4$ & $\begin{array}{l}8.75 / \\
4004\end{array}$ & & $4 / 29 / 82$ & $\begin{array}{l}2413 / \\
30661\end{array}$ & $\begin{array}{l}\text { S17S20/ } \\
30323\end{array}$ & \\
\hline $\mathrm{H}-5$ & $\begin{array}{l}14.75 / \\
2582 \\
\end{array}$ & $\begin{array}{l}7.875 \\
\text { SS }\end{array}$ & $6 / 10 / 82$ & $\begin{array}{l}\text { LAGC-8001/ } \\
6 \mathrm{~A}\end{array}$ & $\begin{array}{l}\text { LAAB-3001/ } \\
\text { MRC-404 }\end{array}$ & $\begin{array}{l}\text { LMOB-7001/ } \\
9\end{array}$ \\
\hline $\mathrm{H}-5$ & $\begin{array}{l}8.75 / \\
3995 \\
\end{array}$ & & $6 / 24 / 82$ & $\begin{array}{l}2413 / \\
29899 \\
\end{array}$ & $\begin{array}{l}S 17520 / \\
30323\end{array}$ & \\
\hline $\mathrm{H}-6$ & $\begin{array}{l}8.75 / \\
3984\end{array}$ & & $10 / 1 / 82$ & $\begin{array}{l}2413 / \\
32946\end{array}$ & $\begin{array}{l}\text { S17S20/ } \\
30323\end{array}$ & \\
\hline P-1 & $\begin{array}{l}9.875 / \\
3920 \\
\end{array}$ & & $1 / 18 / 83$ & $\begin{array}{l}2413 / \\
42587\end{array}$ & $\begin{array}{l}\text { S17S20/ } \\
30323\end{array}$ & \\
\hline P-1 & $\begin{array}{l}6.125 / \\
5910\end{array}$ & & $5 / 3 / 83$ & $\begin{array}{l}2413 / \\
32946\end{array}$ & $\begin{array}{l}\text { S17S20/ } \\
48501\end{array}$ & \\
\hline
\end{tabular}




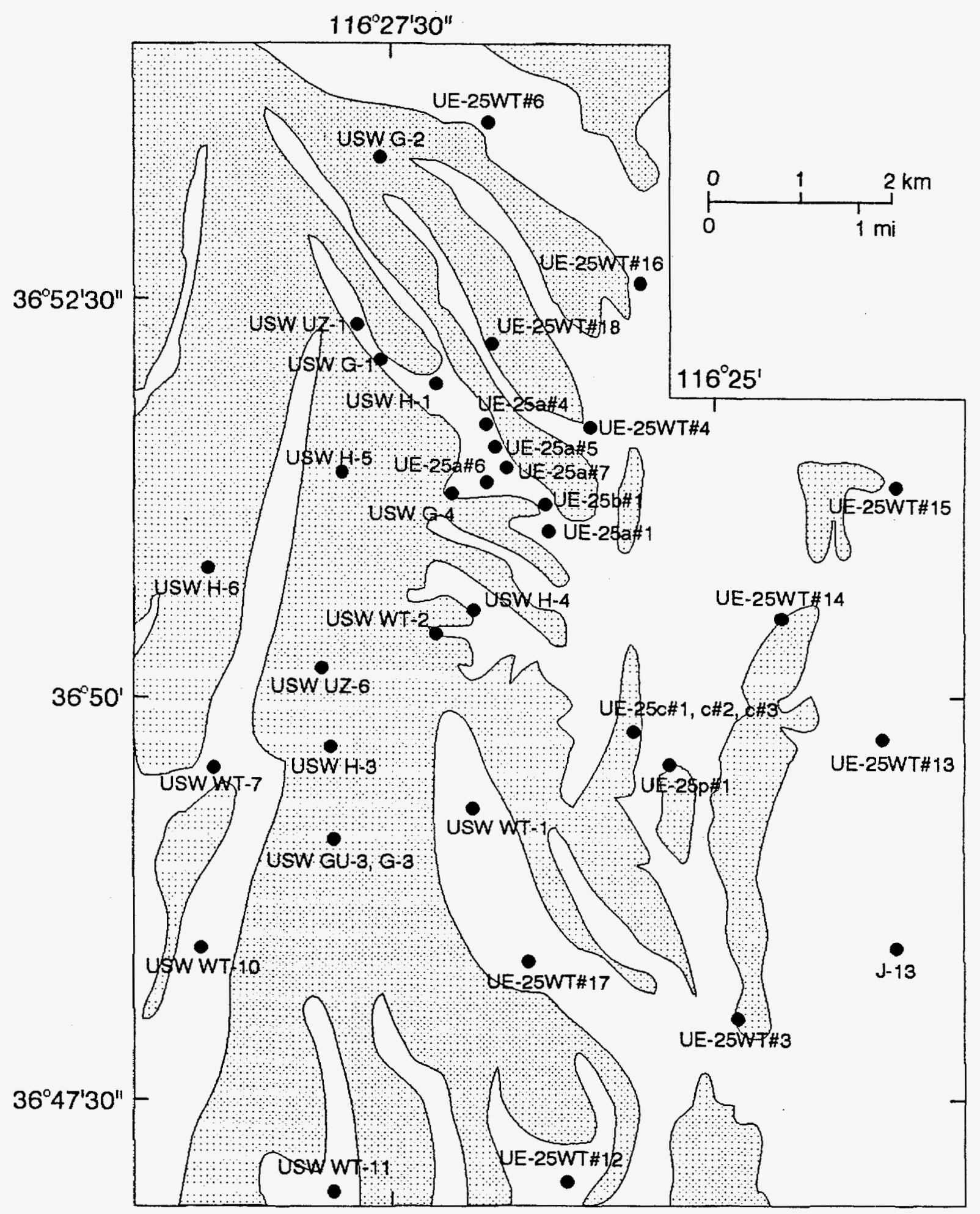

Figure 1. Map of borehole locations at Yucca Mountain, Nevada for boreholes drilled and logged prior to 1985 . 


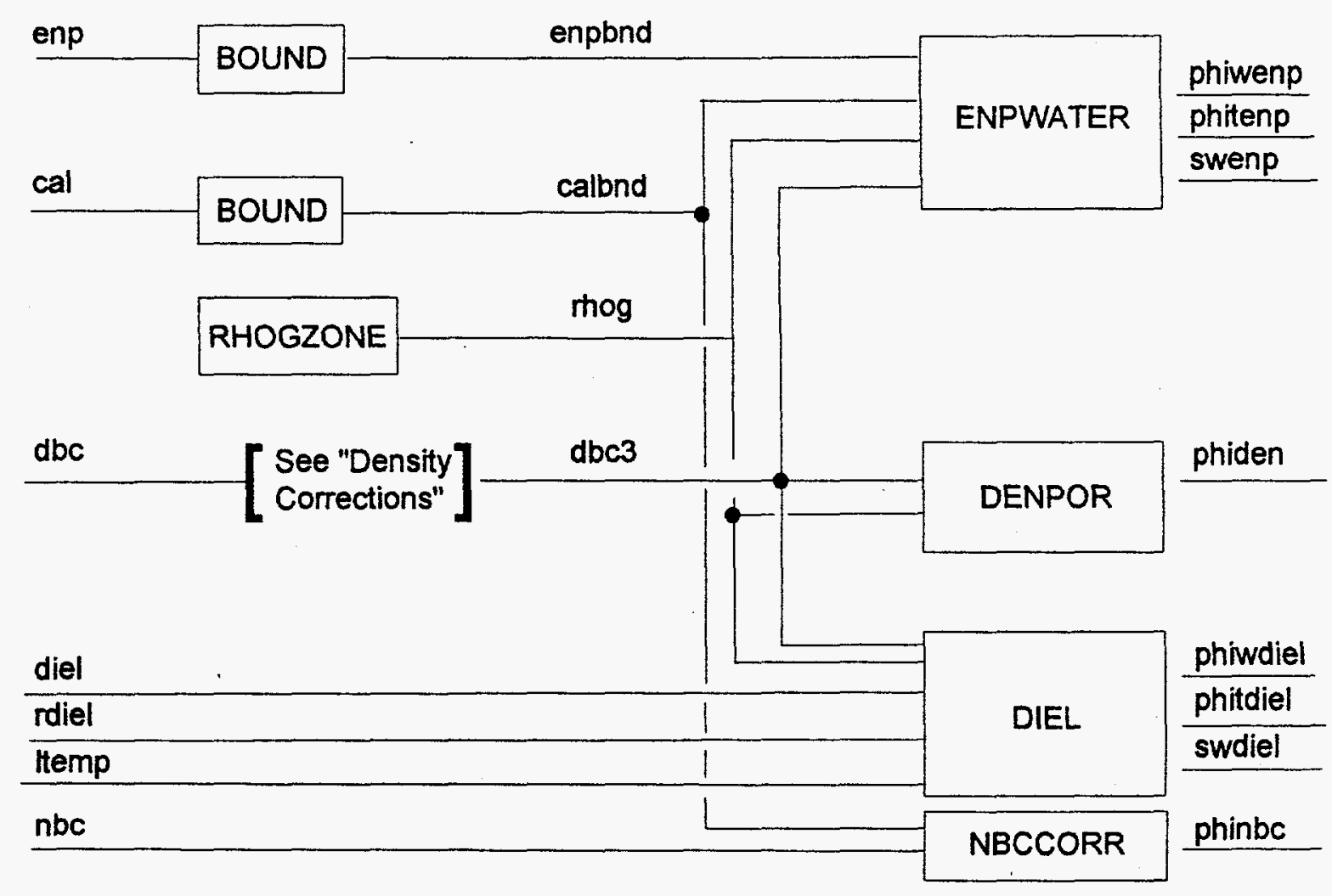

Overview of corrections and porosity computations
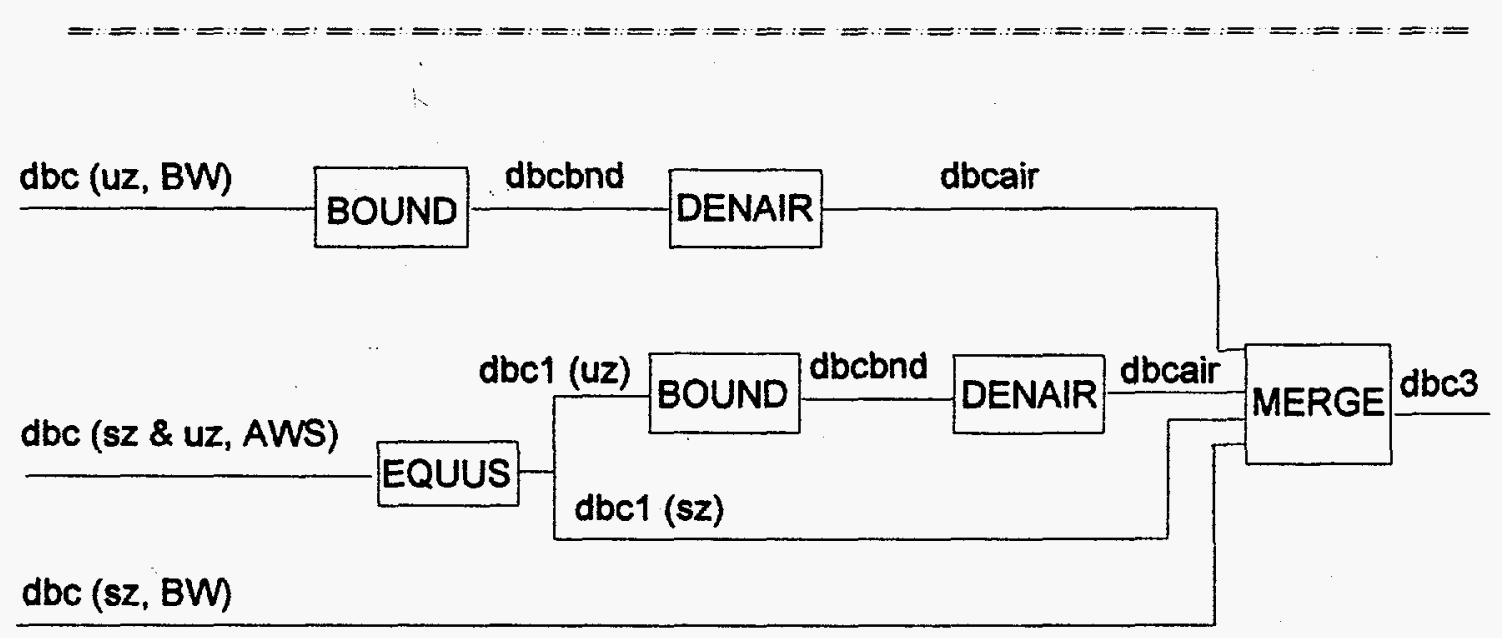

Density Corrections

Figure 2. Overview of corrections applied to logs and computation of water content and porosity. Computations are performed in modules (boxes), log traces are denoted by lower case names (enp, etc.). Abbreviations: air, air-filled hole; water, water-filled hole; BW, Birdwell; AWS, Atlas Wireline Services; uz, unsaturated zone; sz, saturated zone. 
Caliper (cm)

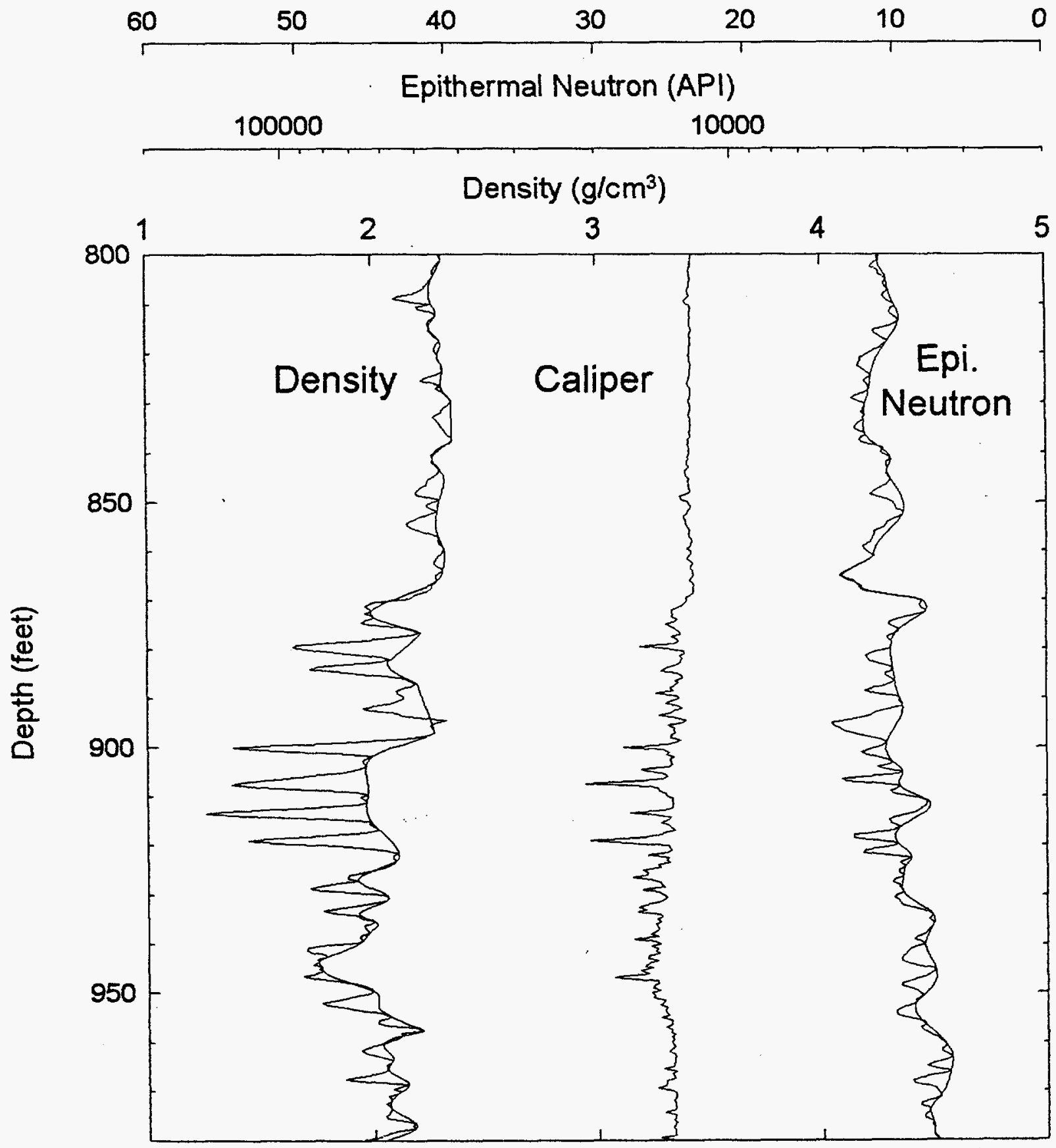

Figure 3. Borehole enlargements shown by caliper log and response of density and neutron logs in unsaturated zone in borehole UE-25WT\#13. Scales are arranged so that enlargements cause logs to deflect to the left. Smooth bounds on right sides of density and epithermal neutron logs are done with spline fit. Interval from 868 to 970 feet is the lower lithhophysal zone of Topopah Spring Tuff. 

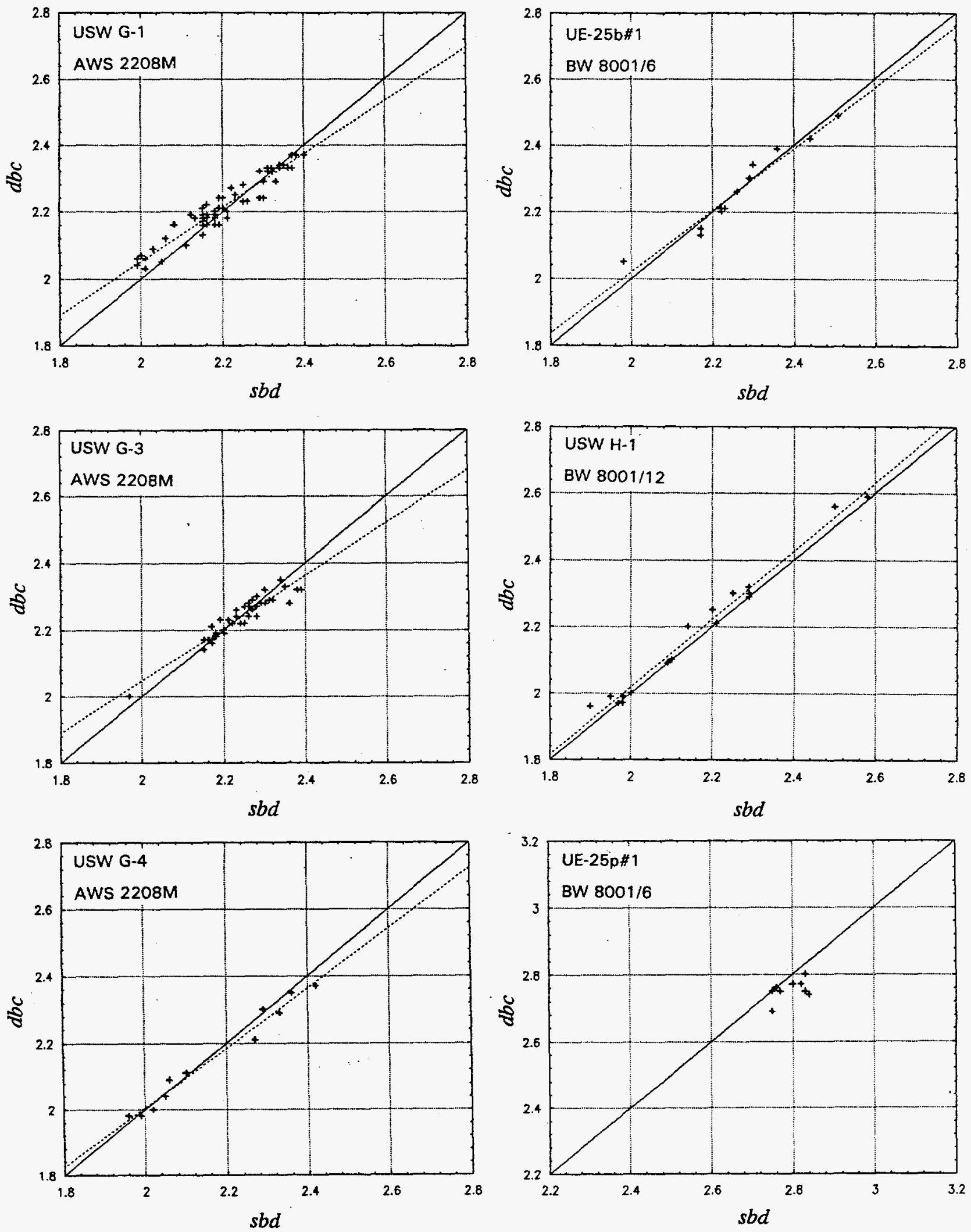

Figure 4. Density $\left(\mathrm{gm} / \mathrm{cm}^{3}\right)$ measured by density $\log (d b c)$ and in the laboratory $(s b d)$ from the saturated zone in six boreholes. Density tools were either the Atlas Wireline Services 2208M tool series (left) or the Birdwell 8001 series (right). Solid lines represent perfect agreement, dashed lines are least-squares $y$-on- $x$ fits. Limestone samples from borehole UE-25p\#1 require a scale shift; samples from the other five boreholes are volcanic tuff. 


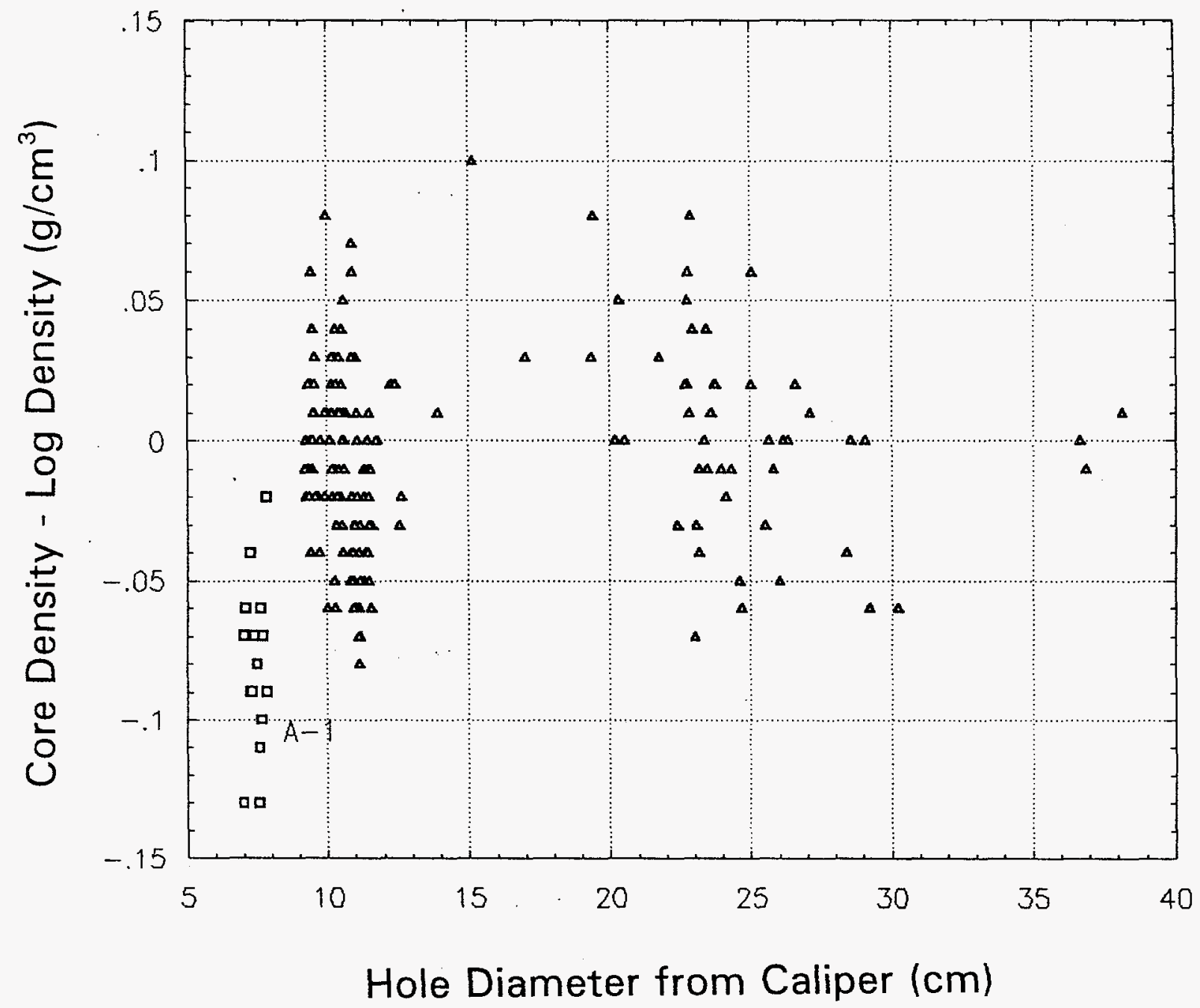

Figure 5. Difference in density measured on core samples and logs from the saturated zone as a function of hole size. Six boreholes are shown as triangles. A seventh borehole, UE-25a\#1, is shown as open squares. 


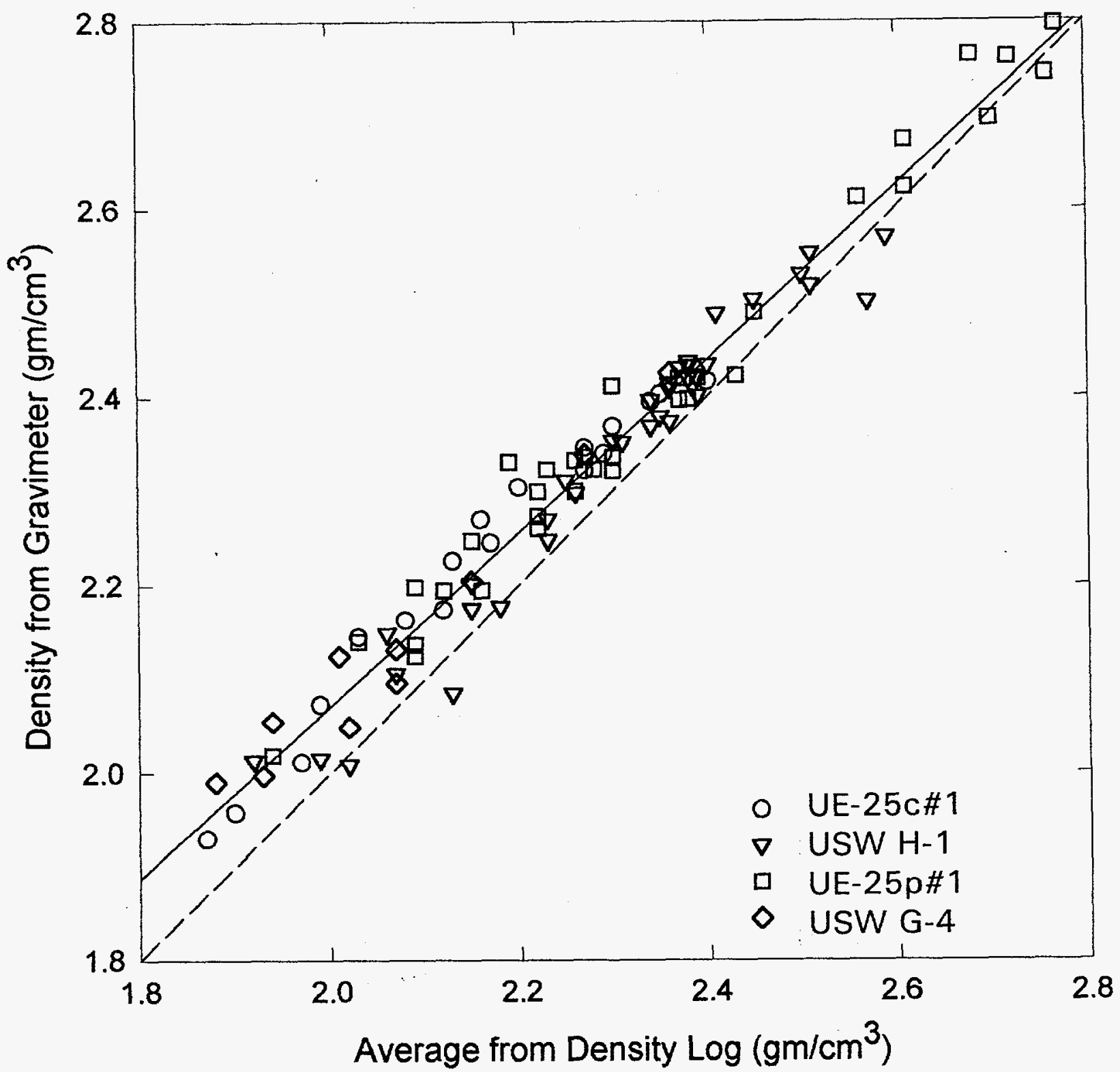

Figure 6. Density from borehole gravimeter vs. density from gamma-gamma density tool, in four boreholes penetrating the saturated zone. Density values from gamma-gamma tool have been averaged over the gravimeter depth intervals. Diagonal dashed line indicates 1:1 match, other line is regression line. 


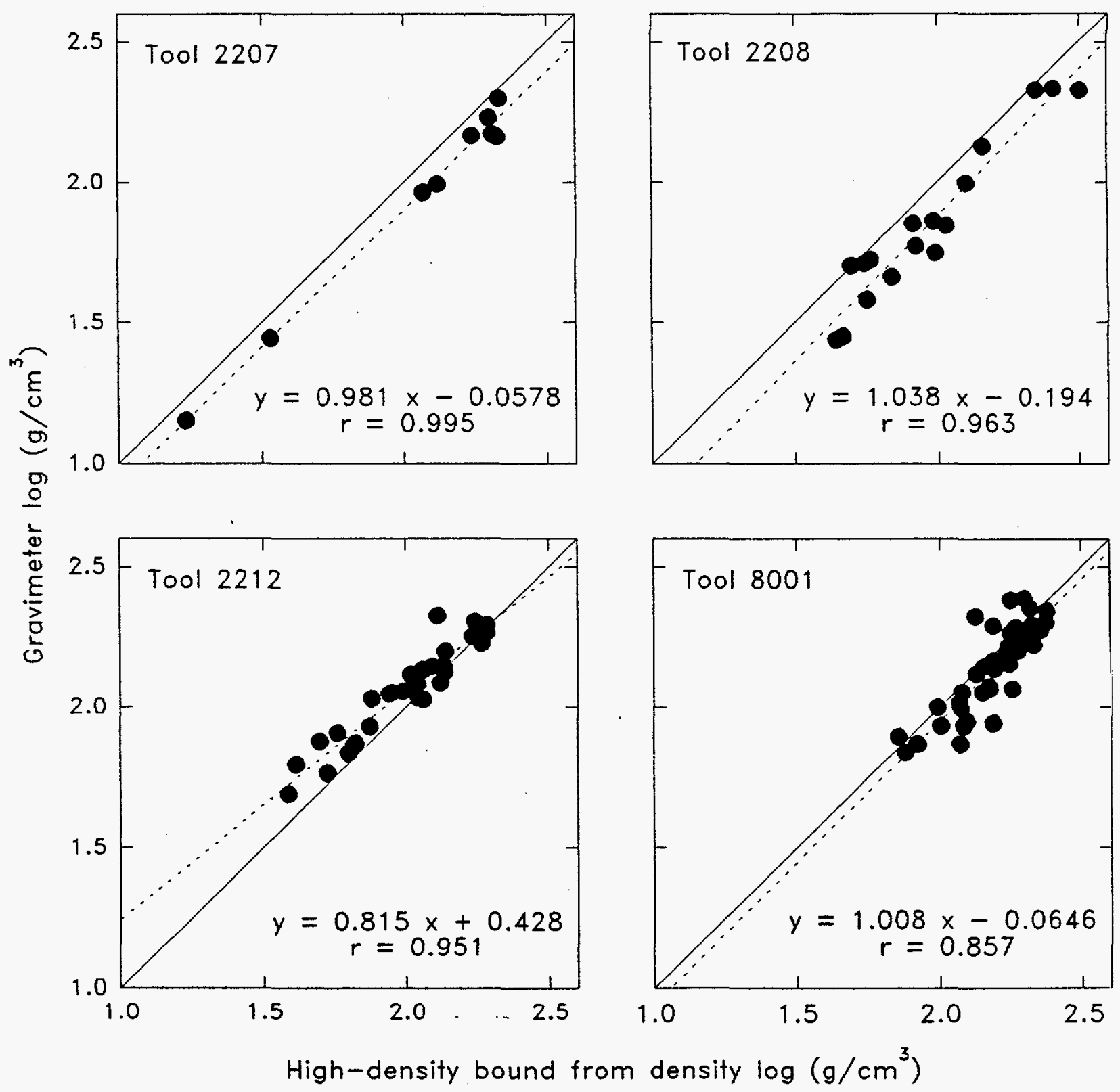

Figure 7. Density from the shifted gravimeter log vs. high-density bound from four density tools. Data taken from the unsaturated zone in four boreholes. Dashed line is $y$-on-x regression fit, solid line is $1: 1$ match. 

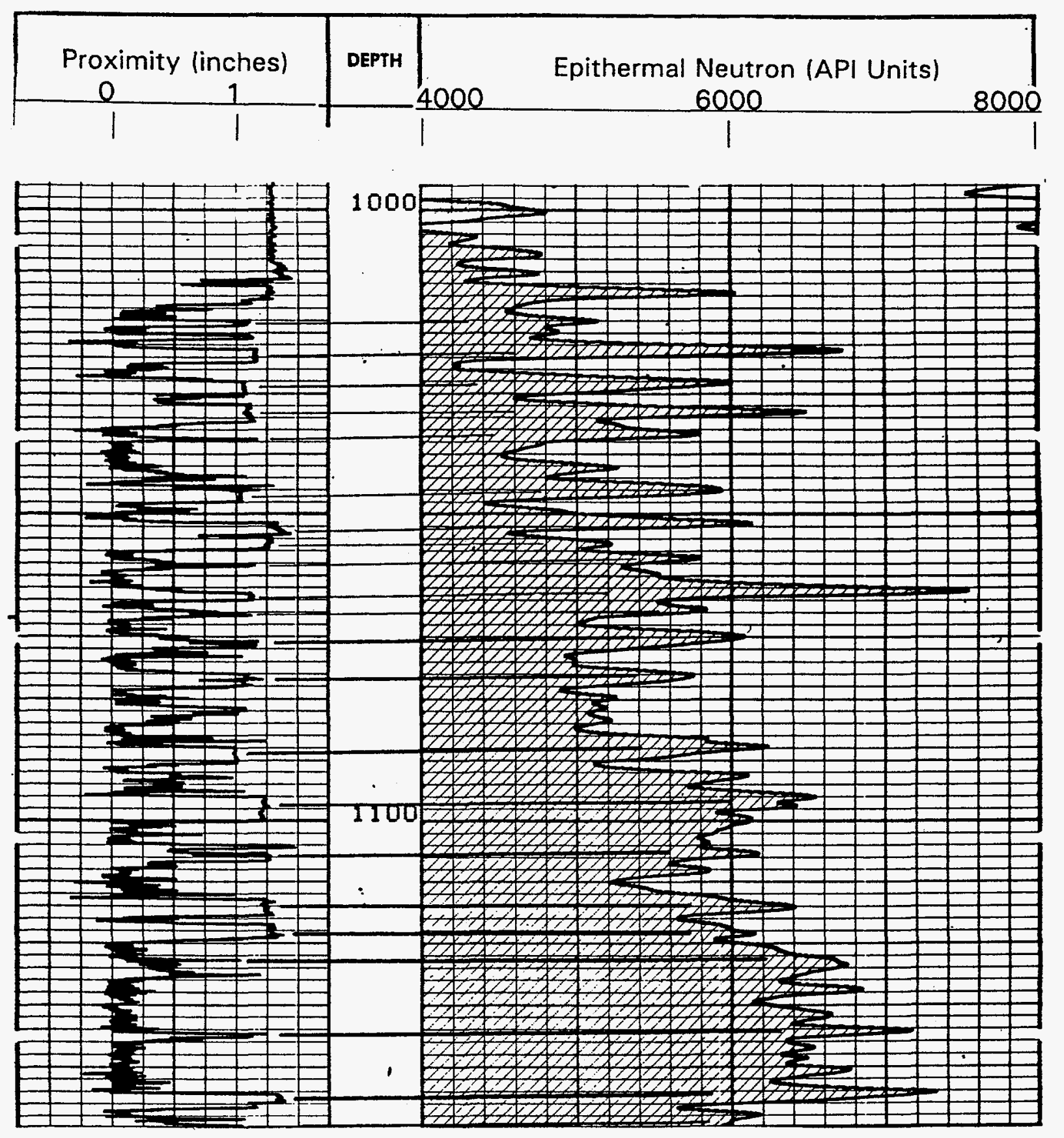

Figure 8. Epithermal neutron log in air-filled borehole in lower lithophysal zone in borehole H-3, dated February 19, 1982. Measurement of gap from the proximity wheel is shown at left. Handdrawn lines connect correlative peaks on proximity and epithermal neutron logs. Depth is in feet below surface. 


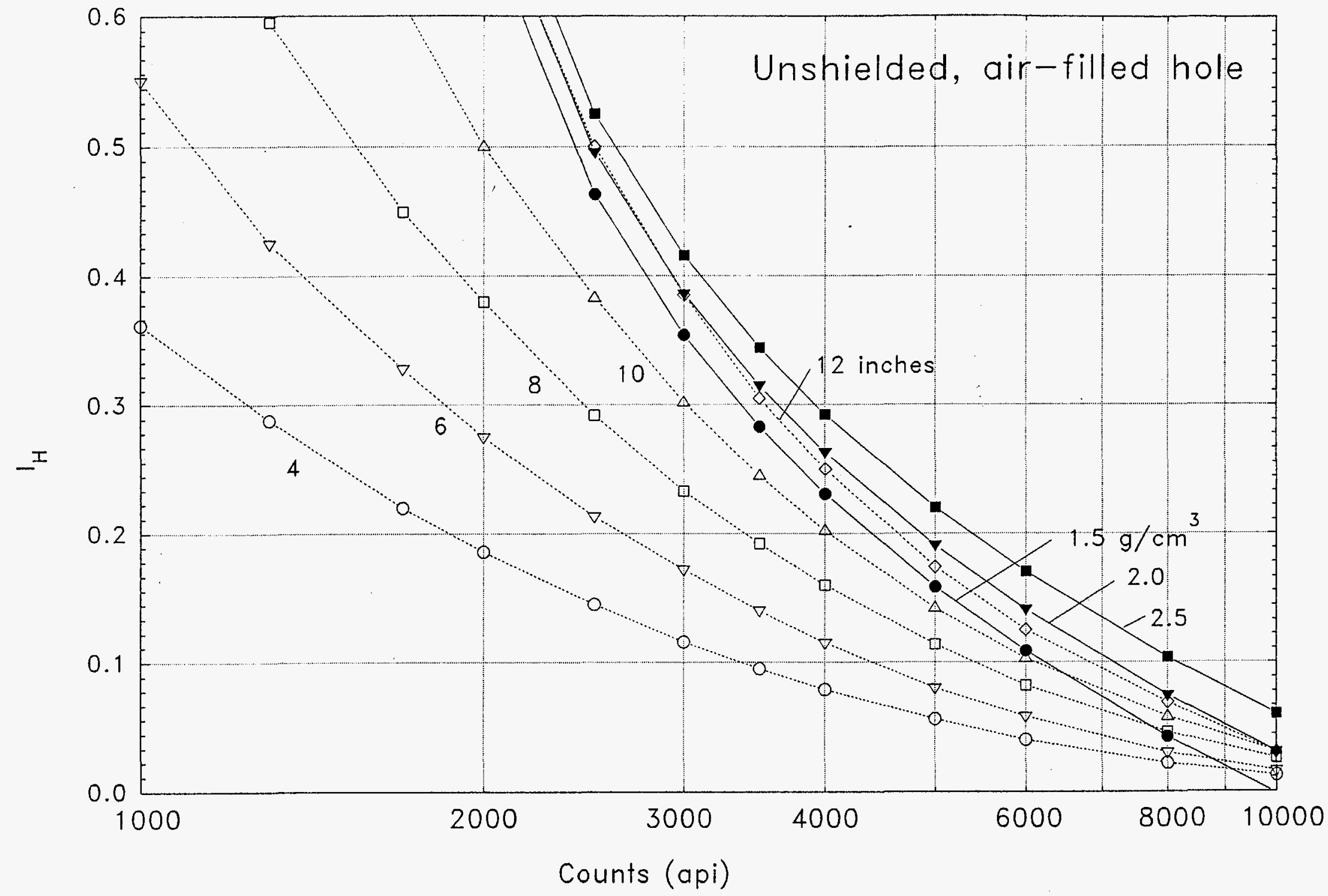

Figure 9. Hydrogen index $I_{H}$ versus count rate from calibration for tool \#193 in HCTF (solid lines for three densities) and from Birdwell chart for an unshielded tool in an air-filled hole with holesize dependence (dashed lines for five hole diameters). 


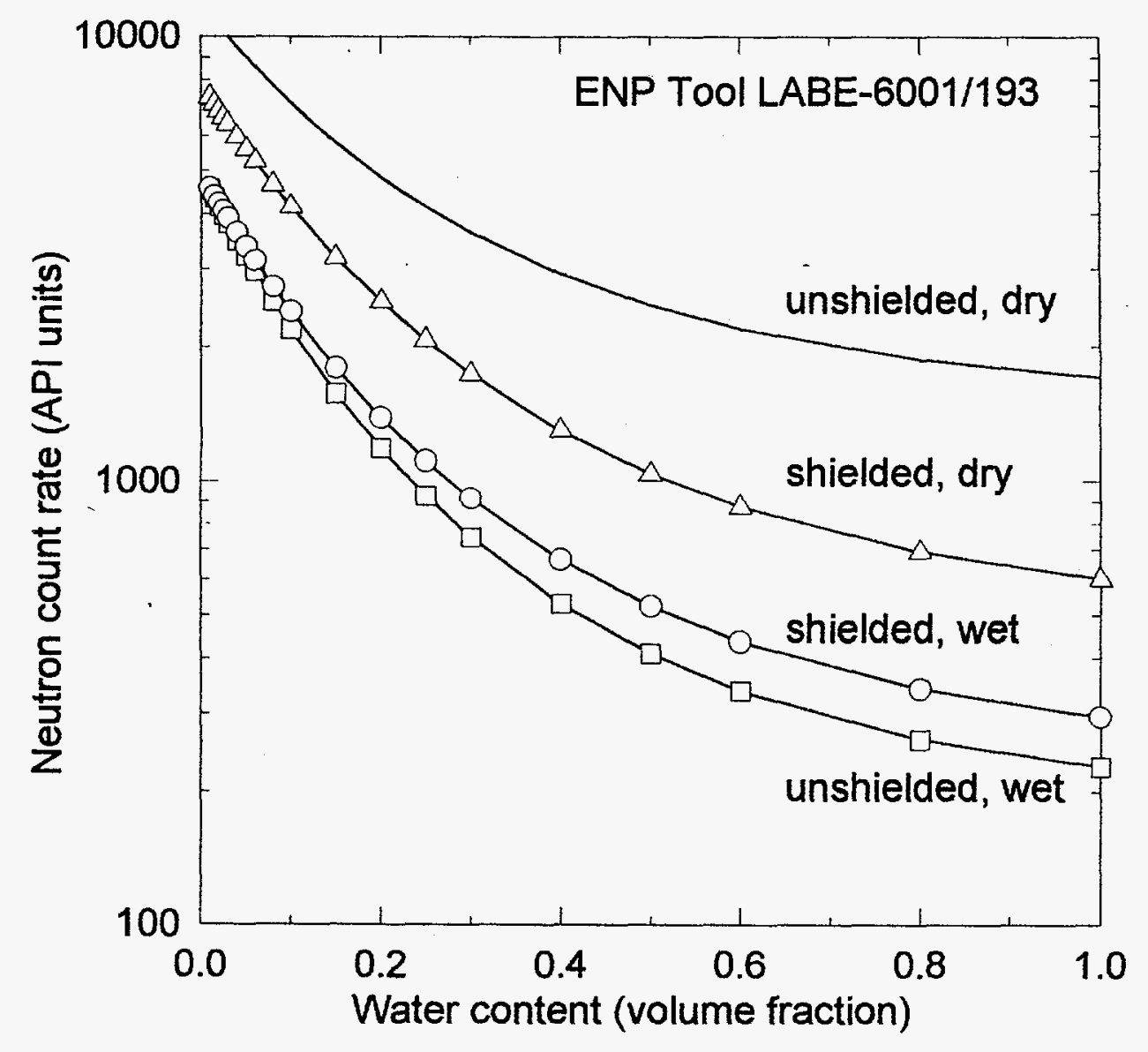

Figure 10. Response curves for ENP tool \#193, computed from algorithm by Hearst et al. (1981) for a density of $2.0 \mathrm{~g} / \mathrm{cm}^{3}$. Coefficients are based on calibration in the HCTF. 


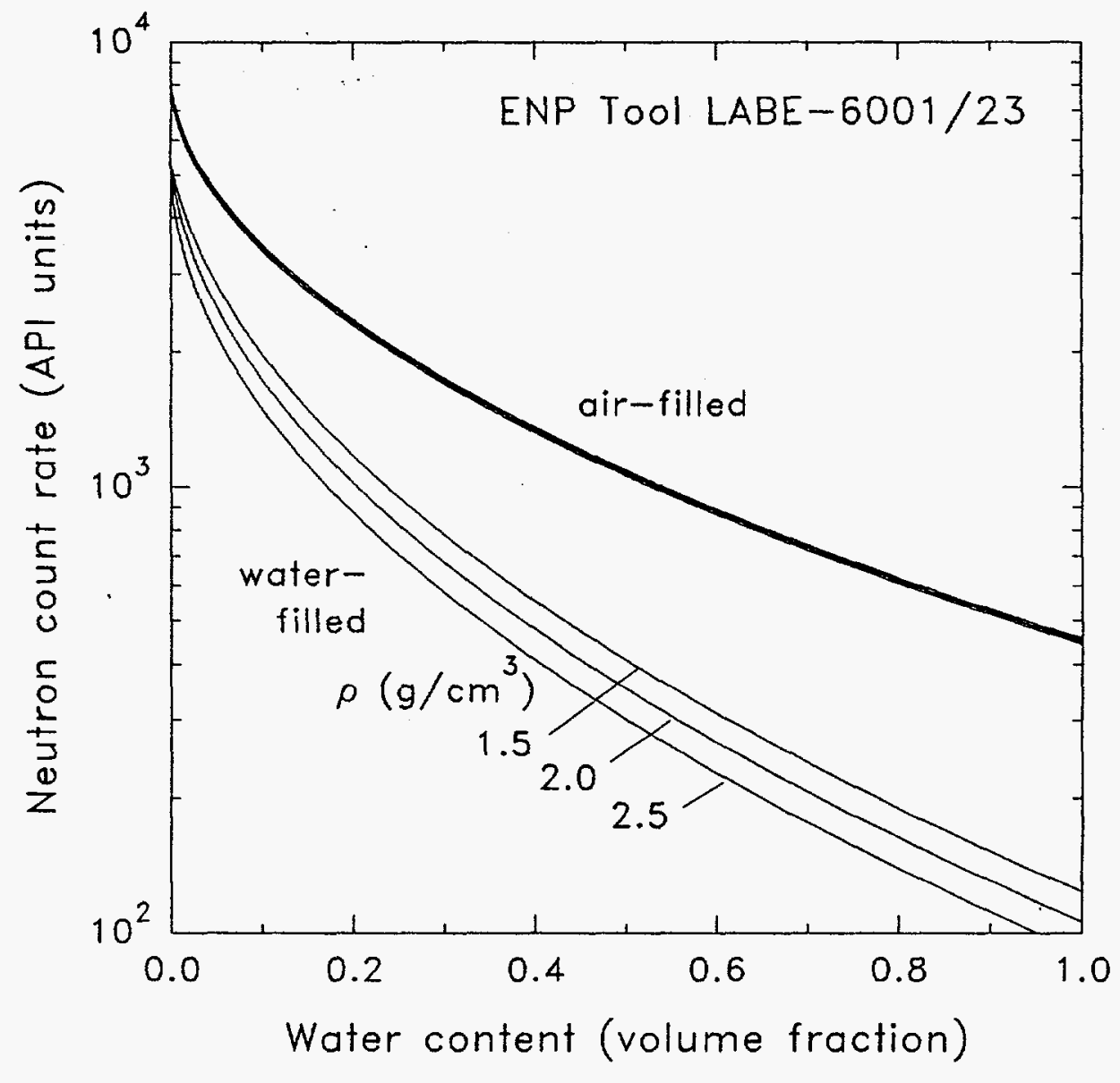

Figure 11. Neutron count rate versus water content, based on calibration in the HCTF of epithermal neutron tool LABE 6001/23, with shield \#2 attached. 


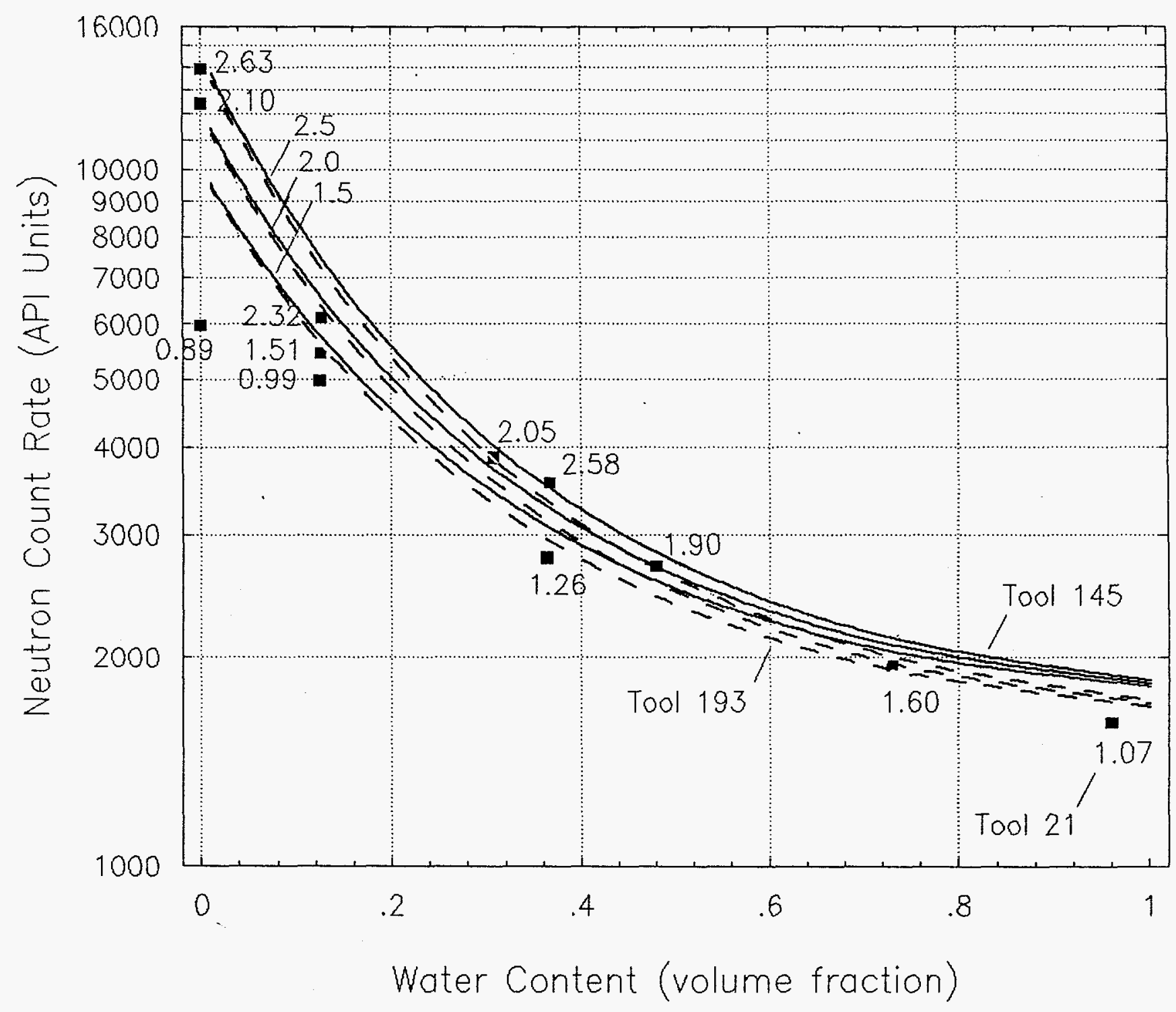

Figure 12. Neutron count rate versus water content for unshielded ENP tools in the 12-inch, airfilled square hole in the HCTF. Symbols: ENP tool model 145 (solid line), model 193 (dashed line), and measurements in HCTF during 1984 for model 21 (solid squares). The three computed curves for models 145 and 193 are shown for densities of $2.5,2.0$, and $1.5 \mathrm{~g} / \mathrm{cm}^{3}$. Values by solid squares for model 21 give the density $\left(\mathrm{g} / \mathrm{cm}^{3}\right)$ of a test cell in HCTF. 


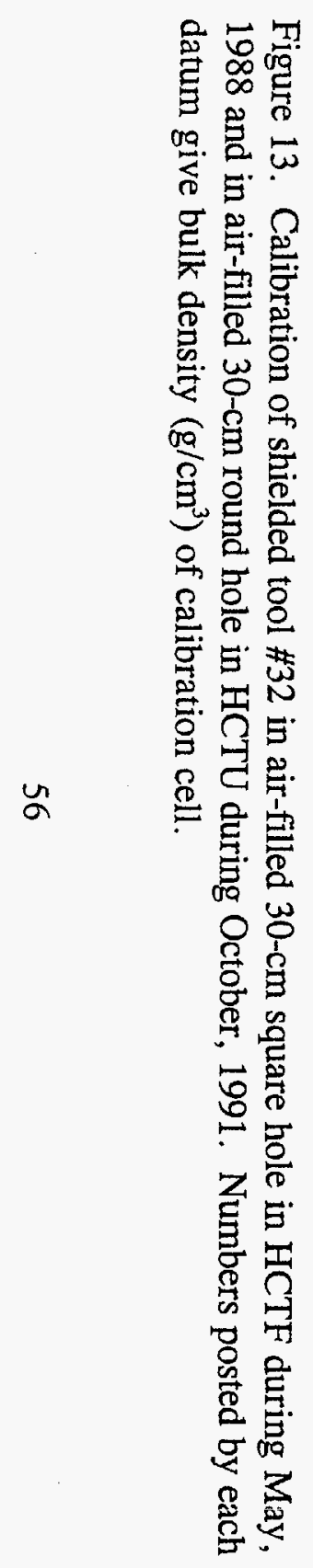

\section{Epithermal Neutron Response (cps)}

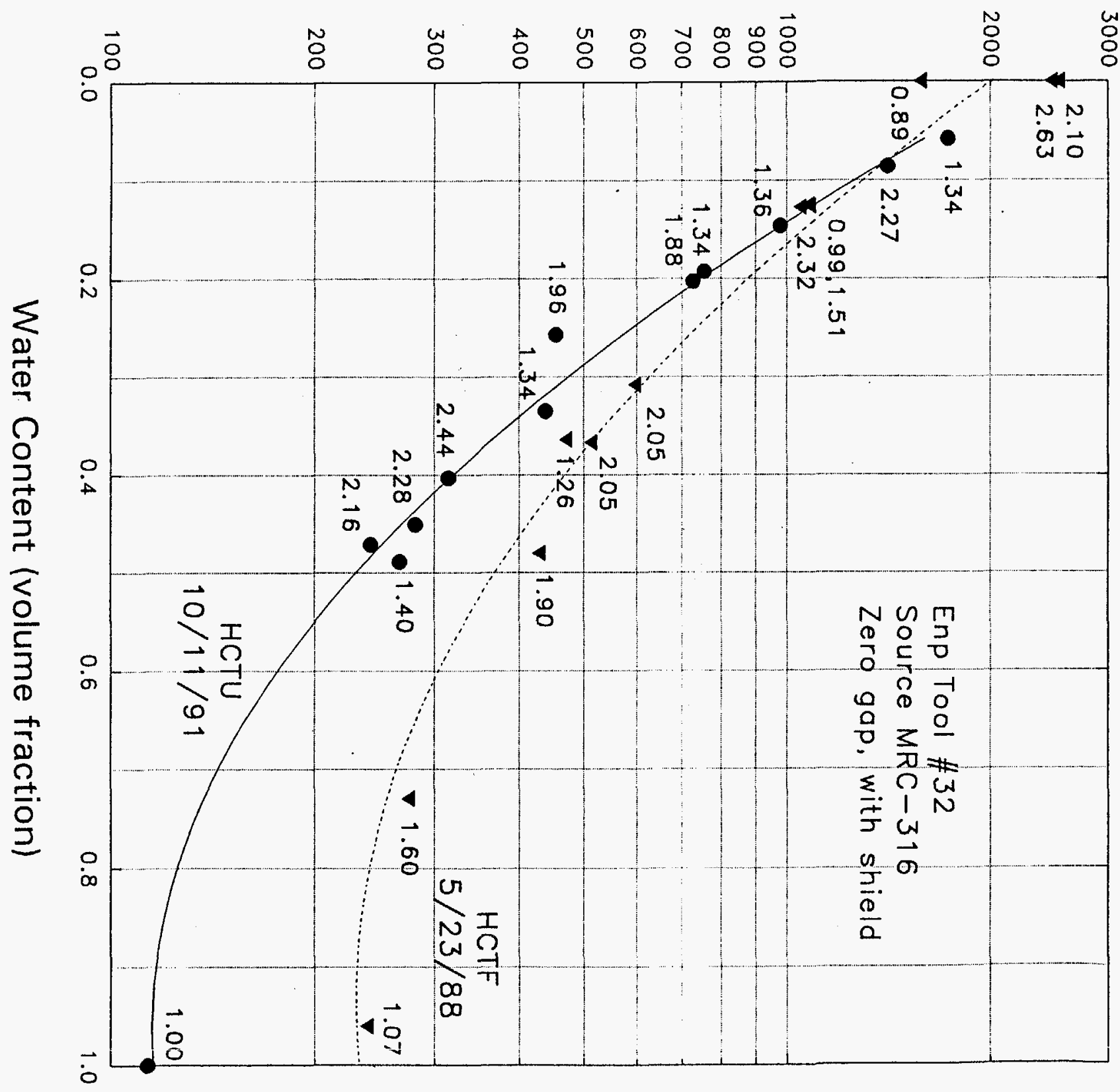




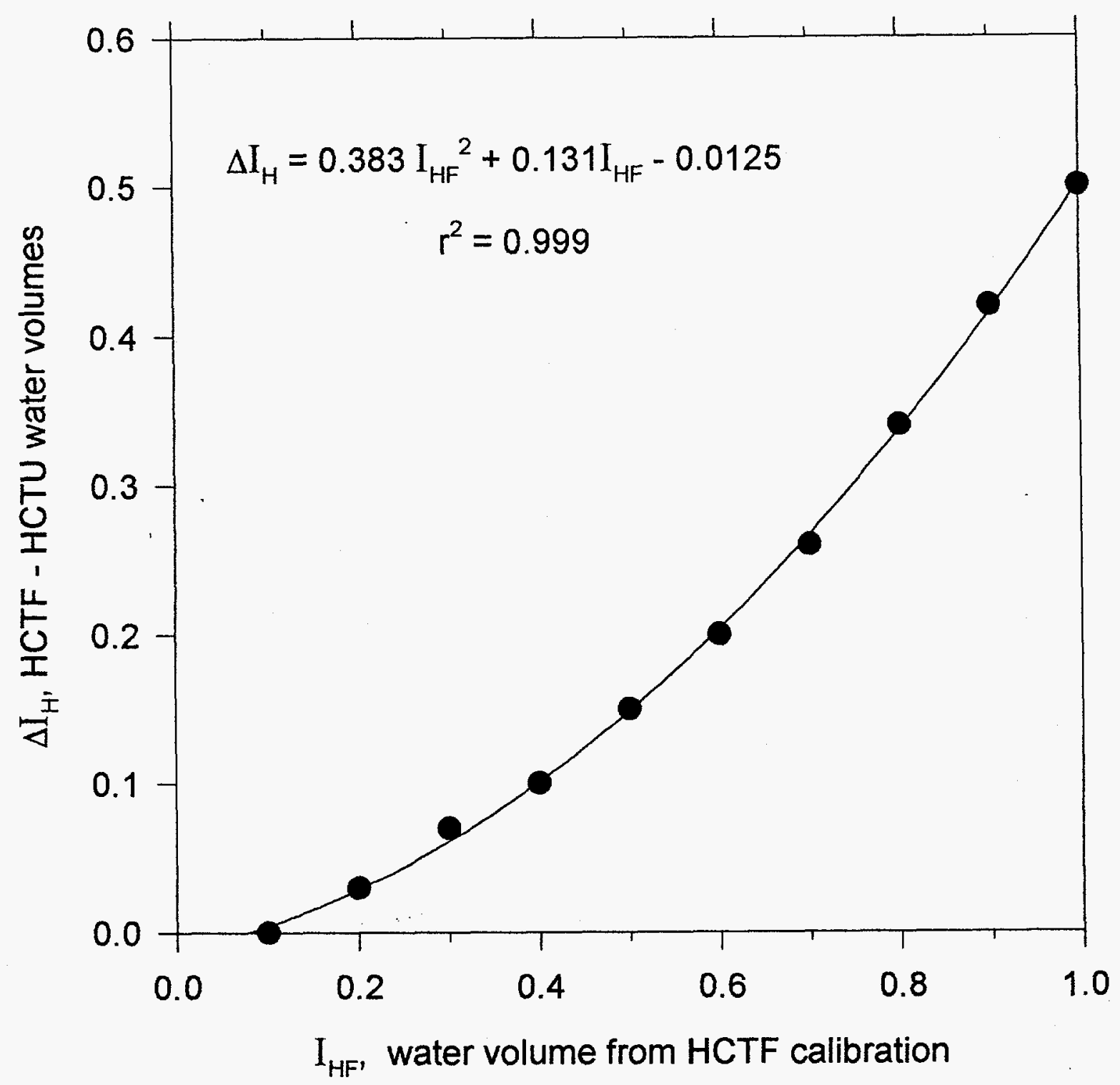

Figure 14. Difference between HCTF and HCTU water content, as function of HCTF water content, based upon calibration of shielded tool \#32 in the air-filled 30-cm square hole in HCTF during May, 1988 and in air-filled 30-cm round hole in HCTU during October, 1991. Quadratic fit is valid for $0.1<\mathrm{I}_{\mathrm{HF}}<1.0$. 


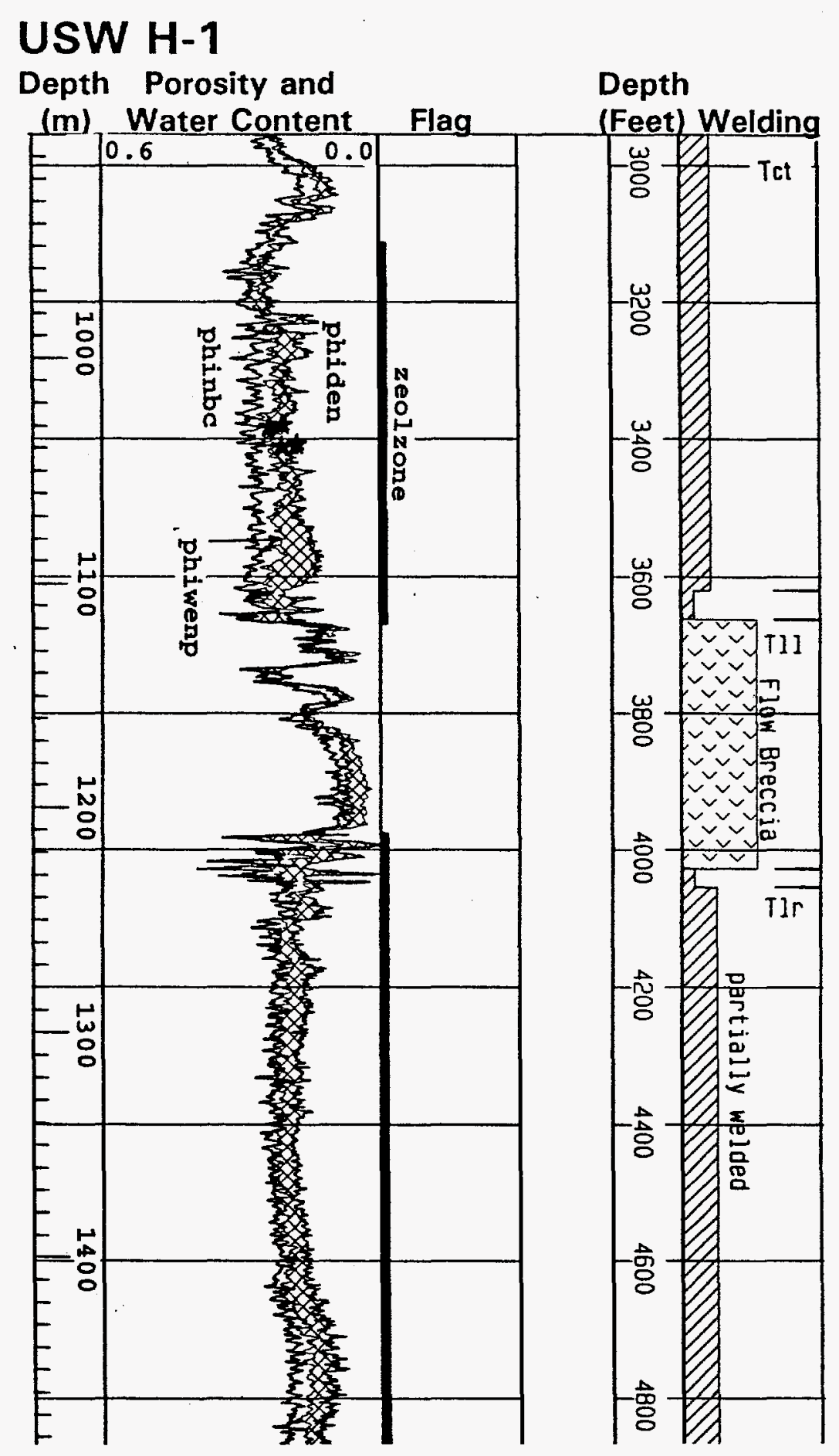

Figure 15. Results of computations below static water level in borehole USW H-1: water content from the epithermal neutron $\log$ (phiwenp), water content from the thermal neutron log (phinbc), and porosity from the density log (phiden). Black bars (zeolzone) are log-based picks of the zeolitic zones. Stars represent porosity measurements on core samples. Logs penetrate the Tram Tuff (Tct), a flow breccia (Tll), and Lithic Ridge Tuff (Tlr). Nominal depth of static water level is 1876 feet. 


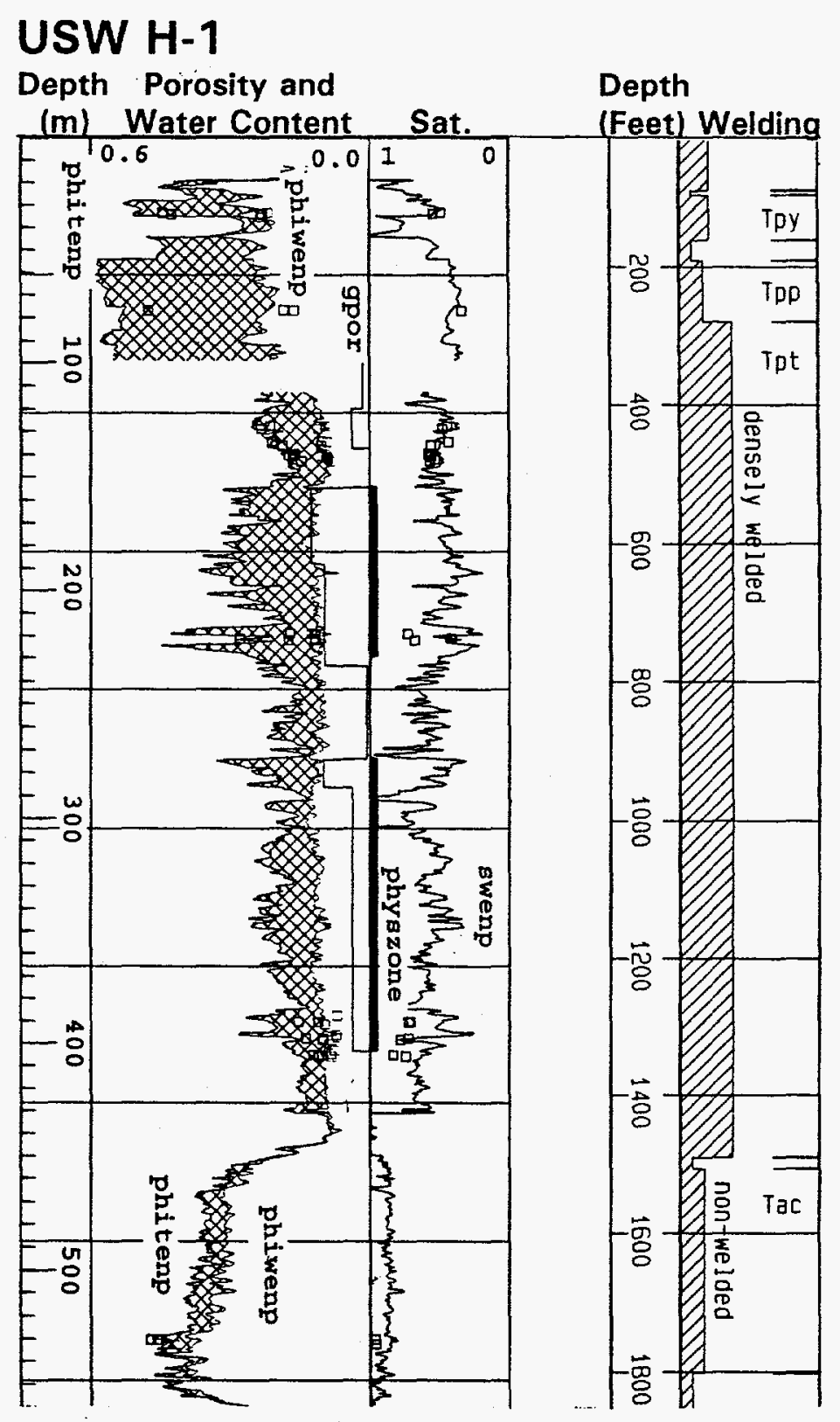

Figure 16. Results of water content from the epithermal neutron log (phiwenp), porosity (phitenp), and saturation (swenp) computations in borehole USW H-1. Cross-hatching shows airfilled porosity. Curve gpor gives an estimate of lithophysal pore volume, from Muller and Spengler (1989). Black bars (physzone) are log-based picks of the lithophysal zones. Logs penetrate the Yucca Mountain Tuff (Tpy), Pah Canyon Tuff (Tpp), and Topopah Spring Tuff (Tpt) of the Paintbrush Group and the Calico Hills Formation (Tac). Nominal depth of static water level is 1876 feet, below the lowermost depth of the figure. 


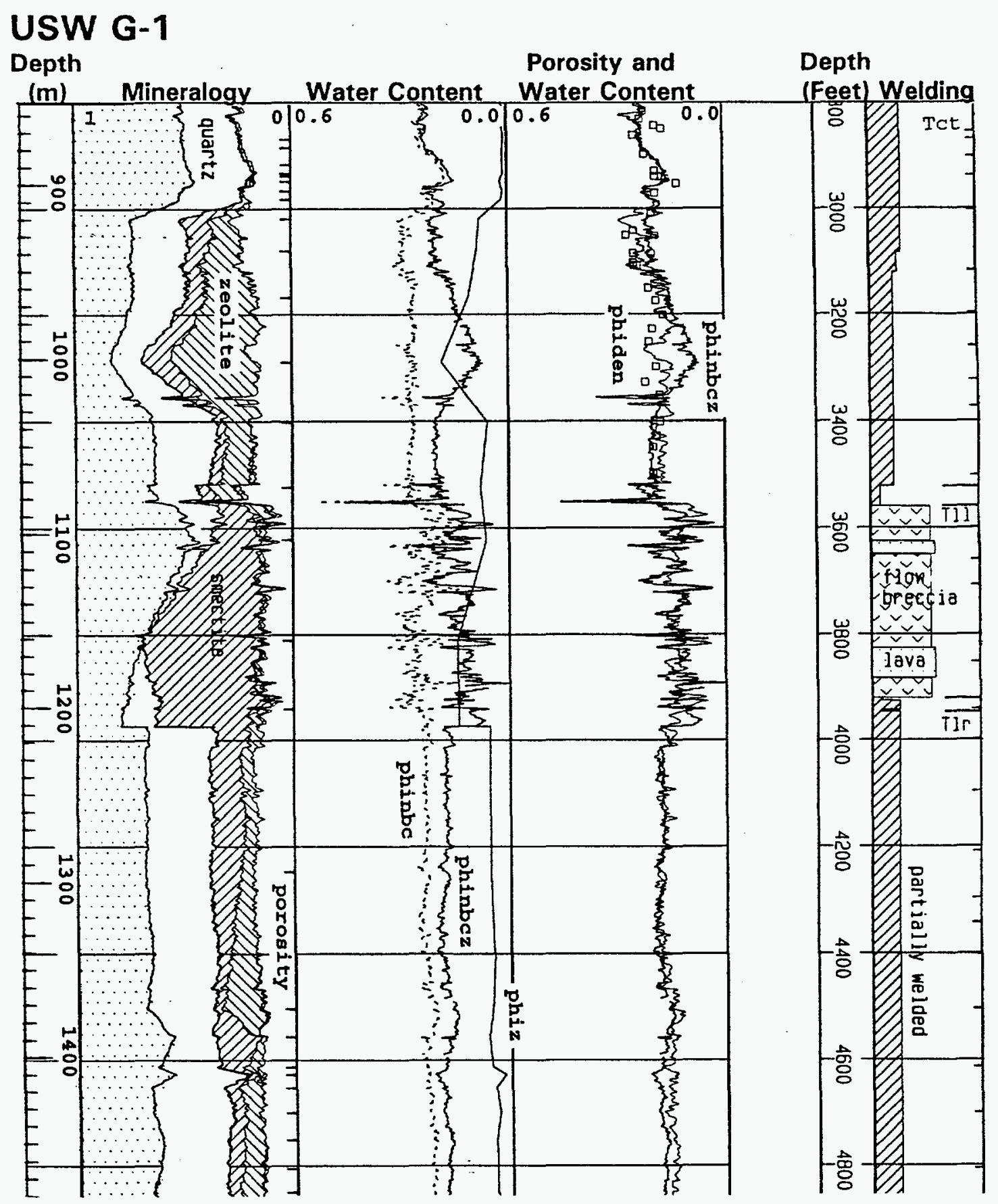

Figure 17. Results of water content and porosity computations below static water level in borehole USW G-1: total water from thermal neutron $\log (\mathrm{phinbc})$, structural water (phiz), and pore water by difference (phinbcz). Porosity (phiden in column 3 ) has also been used to compute the mineralogical volume fractions in column 1; mineralogy by X-ray diffraction taken from Bish and Chipera (1989). Short ticks in column 1 show the depths of X-ray diffraction samples. Logs penetrate the Tram Tuff (Tct), a flow breccia (T11), and Lithic Ridge Tuff (Tlr). Nominal elevation of static water level is 1875 feet. 


\section{USW G-1}

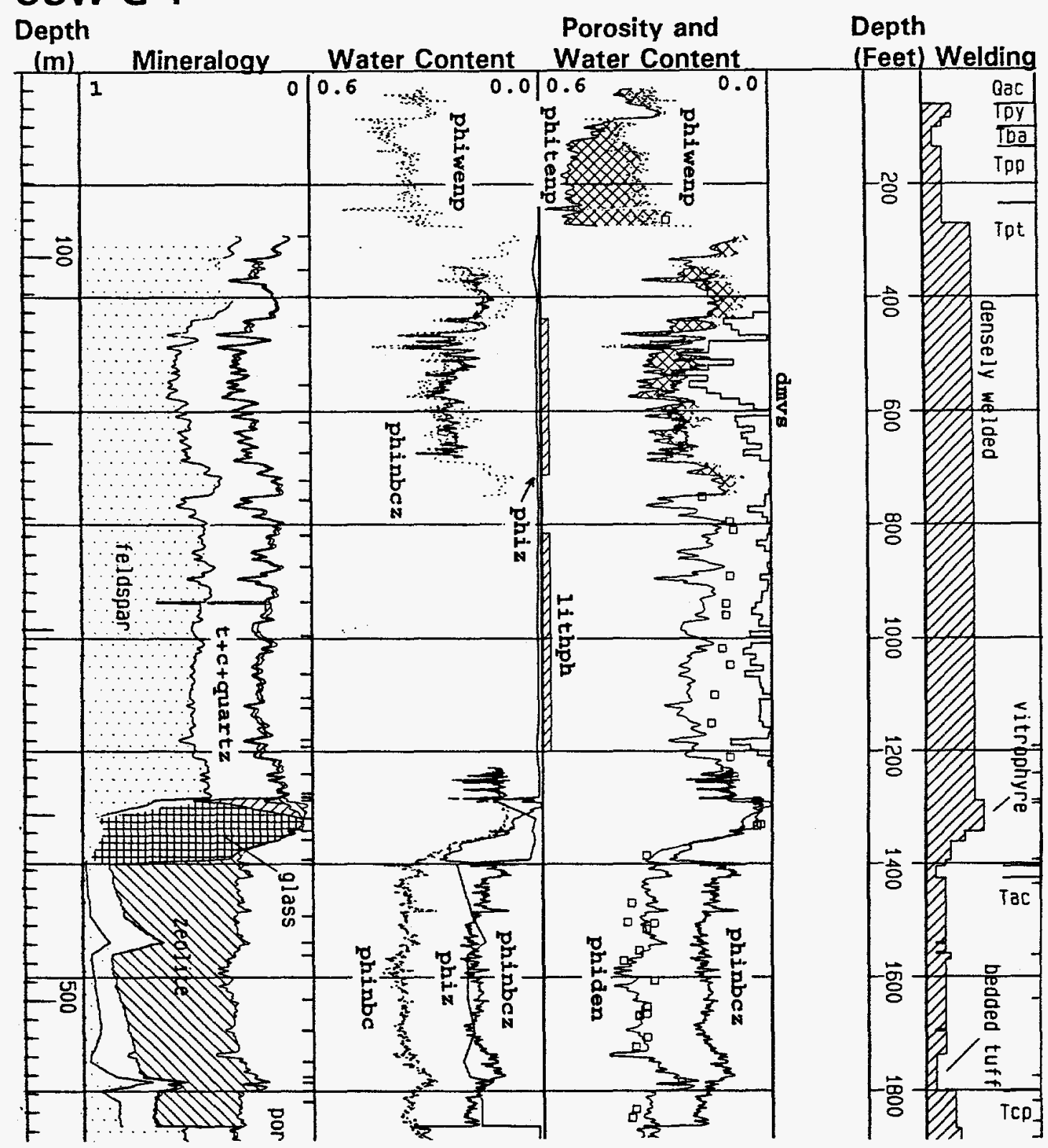

Figure 18. Results of computations above static water level in borehole USW G-1: water content from epithermal neutron log (phiwenp), thermal neutron $\log$ (phinbc), and porosity (phiden and phitenp). Pore water (phinbcz) is obtained by subtracting structural water (phiz) from phinbc. Porosity (phiden in column 3 ) has also been used to compute the mineralogical volume fractions in column 1; mineralogy by X-ray diffraction taken from Bish and Chipera (1989). Short ticks in column 1 show the depths of $\mathrm{X}$-ray diffraction samples; $\mathrm{t}+\mathrm{c}+$ quartz represents tridymite plus cristobalite plus quartz. Logs penetrate the Yucca Mountain Tuff (Tpy), Pah Canyon Tuff (Tpp), and Topopah Spring Tuff (Tpt) of the Paintbrush Group and the Calico Hills Formation (Tac). Nominal elevation of static water level is 1875 feet. 


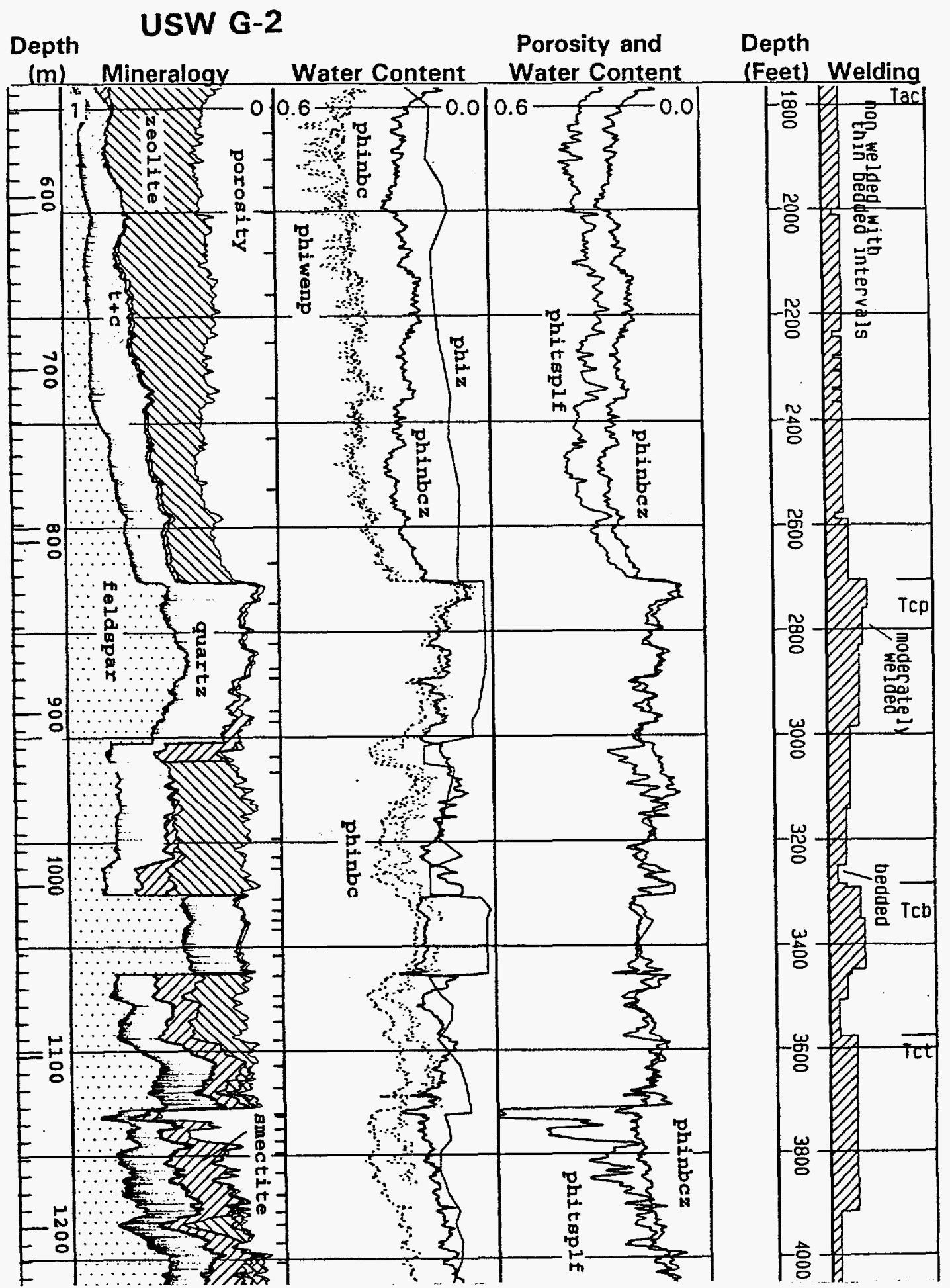

Figure 19. Results of water content and porosity computations in borehole USW G-2. Total water from epithermal log (phiwenp, light dots), total water from thermal neutron log (phinbc, dark dots), structural water (phiz), and pore water by difference (phinbcz). Porosity (phitsplf) has been used to compute the mineralogical volume fractions in column 1. Mineralogy by X-ray diffraction taken from Bish and Chipera (1989); short ticks in column 1 show sample depths. Logs penetrate the Calico Hills Formation (Tac) and the Prow Pass, Bullfrog, and Tram Tuffs (Tcp, Tcb, Tct). Nominal elevation of static water level is slightly above the top of Tac, true elevation is under study. 


\section{USW WT-11}

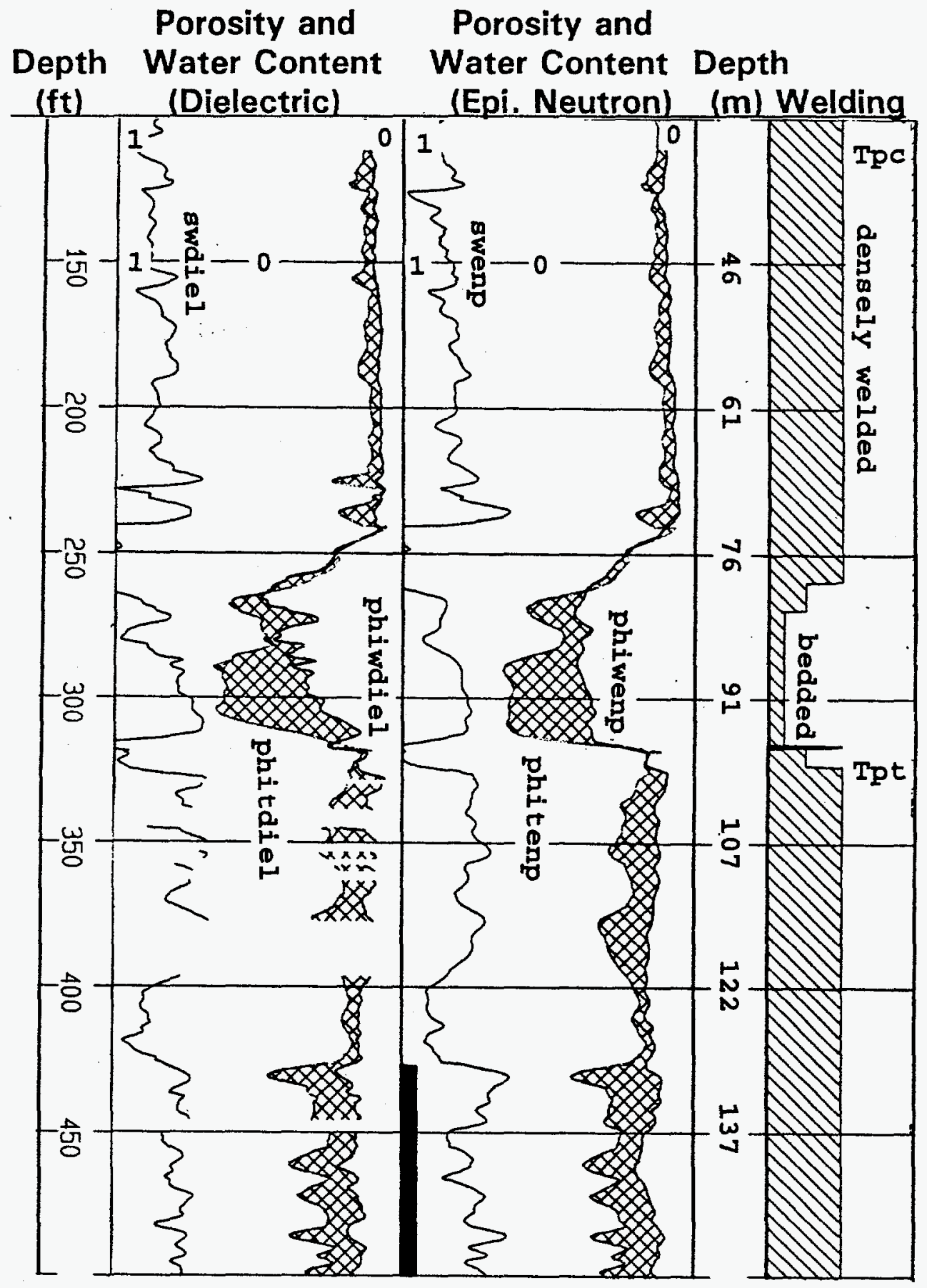

Figure 20. Results from computations in borehole USW WT-11. Epithermal neutron log: water content (phiwenp), porosity (phitenp), and saturation (swenp). Dielectric log: water content (phiwdiel), porosity (phitdiel), and saturation (swdiel). Black bar indicates the top of the upper lithophysal zone. Logs penetrate the Tiva Canyon Tuff (Tpc) and Topopah Spring Tuff (Tpt) of the Paintbrush Group. Nominal depth of static water level is 1193 feet. 

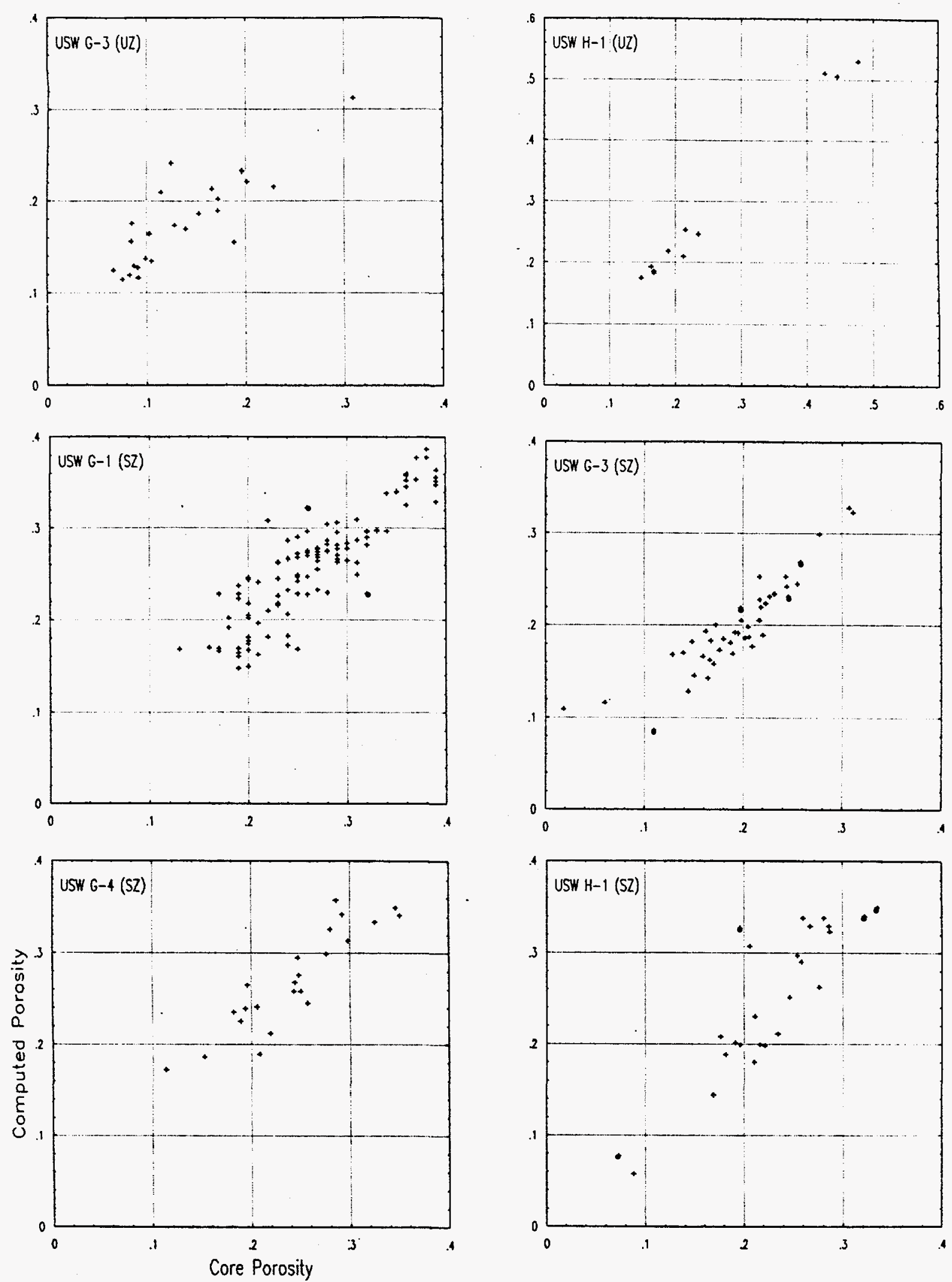

Figure 21. Computed porosity vs. core porosity in six intervals, for cases listed in table 9. 